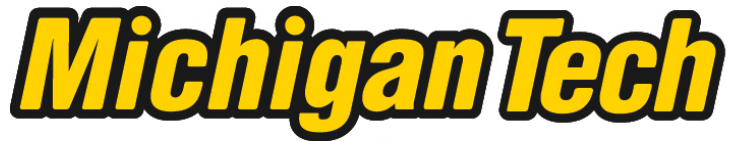 \\ Michigan Technological University Create the Future Digital Commons @ Michigan Tech
}

\section{ECONOMIC PROFITABILITY OF THE BAKKEN, NORTH DAKOTA UNCONVENTIONAL OIL PLAYS BASED ON A TYPICAL WELL PERFORMANCE WITH CURRENT MARKET CONDITIONS}

Mehmet Apaydin

Michigan Technological University

Follow this and additional works at: https://digitalcommons.mtu.edu/etds

Part of the Economics Commons, Finance and Financial Management Commons, and the Petroleum Engineering Commons

Copyright 2014 Mehmet Apaydin

\section{Recommended Citation}

Apaydin, Mehmet, "ECONOMIC PROFITABILITY OF THE BAKKEN, NORTH DAKOTA UNCONVENTIONAL OIL PLAYS BASED ON A TYPICAL WELL PERFORMANCE WITH CURRENT MARKET CONDITIONS", Master's Thesis, Michigan Technological University, 2014.

https://doi.org/10.37099/mtu.dc.etds/866

Follow this and additional works at: https://digitalcommons.mtu.edu/etds

Part of the Economics Commons, Finance and Financial Management Commons, and the Petroleum Engineering Commons 


\title{
ECONOMIC PROFITABILITY OF THE BAKKEN, NORTH DAKOTA \\ UNCONVENTIONAL OIL PLAYS BASED ON A TYPICAL WELL PERFORMANCE WITH CURRENT MARKET CONDITIONS
}

By

Mehmet Apaydin

\begin{abstract}
A THESIS
Submitted in partial fulfillment of the requirements for the degree of MASTER OF SCIENCE

In Applied Natural Resource Economics
\end{abstract}

MICHIGAN TECHNOLOGICAL UNIVERSITY

2014

C2014 Mehmet Apaydin 
This thesis has been approved in partial fulfillment of the requirements for the Degree of MASTER OF SCIENCE in Applied Natural Resource Economics.

School of Business and Economics

Thesis Co-Advisor: Dr. Mark C. Roberts

Thesis Co-Advisor: Dr. Gary A. Campbell

Committee Member: Dr. Roger Turpening

School Dean: $\quad$ Dr. R. Eugene Klippel 


\section{Dedication}

I would like to dedicate this thesis to my family and the Turkish Petroleum

Corporation. 


\section{Table of Contents}

List of Figures ............................................................................................................................ vi

List of Tables.............................................................................................................. viii

Abstract.............................................................................

1. Introduction \& Background .......................................................................... 1

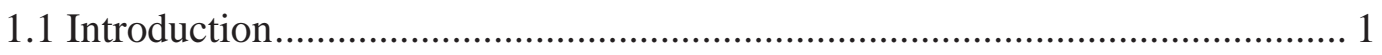

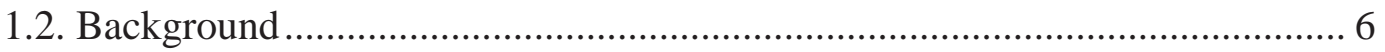

\section{Economic and Environmental Issues linked with Unconventional Oil}

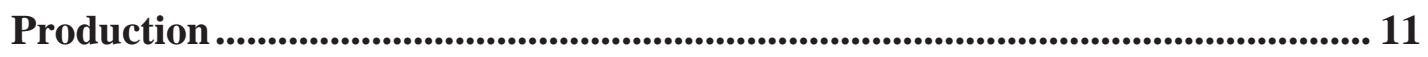

2.1. Unconventional Production Cost .................................................................. 12

2.2. Production Decline Rates..................................................................... 14

2.3. Oil Price Volatility, Transportation and Refinery Issues................................. 17

2.4. Environmental and Social Concerns........................................................... 21

2.5. Recent Bakken Operations...................................................................... 23

3. Methodology ............................................................................................................. 25

3.1. North Dakota Bakken Unconventional Oil Prices ........................................ 26

3.2. Total Drilling and Completion Costs............................................................. 27

3.3. Lease Agreements and Royalty Payments................................................. 28

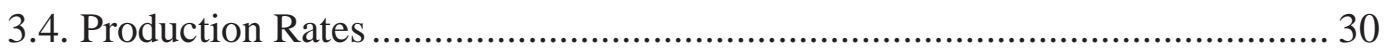

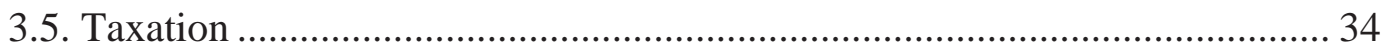

3.5.1. North Dakota State Taxes ..................................................................... 34

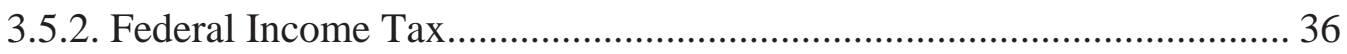

3.6. Lease Operating Expenses (LOE) .............................................................. 37

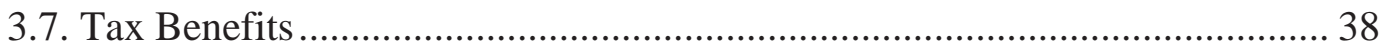

3.7.1. Tax Deductions for Intangible Drilling Cost ………………………..... 38

3.7.2. Tax Deductions for Tangible Drilling Cost ............................................ 38

3.7.3. Depletion Allowance ........................................................................... 40 


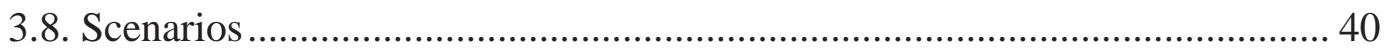

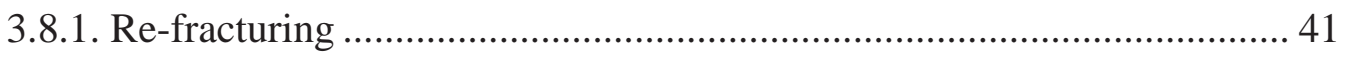

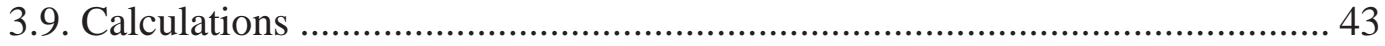

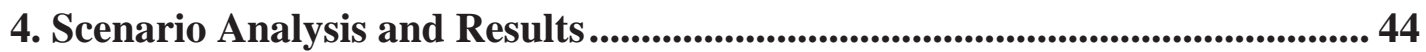

4.1. Typical Bakken unconventional oil well (Simulated well) ............................ 44

4.1.1. Production Decline Curve for the First Scenario ..................................... 46

4.1.2. Production Decline Curve for the Second Scenario.................................. 49

4.1.3. Production Decline Curve for the Third Scenario..................................... 51

4.1.4. Production Decline Curve for the Fourth Scenario................................... 53

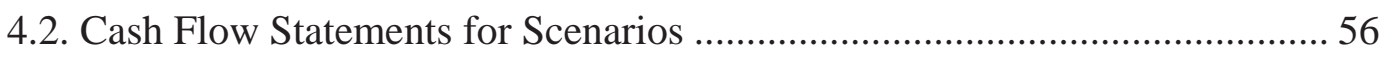

4.2.1. First Scenario (5 years production) ………………................................ 56

4.2.2. Second Scenario (10 years production) .................................................... 59

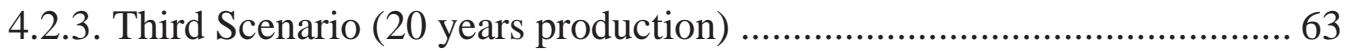

4.2.4. Fourth Scenario (Another well drilled in year ten) ................................. 69

4.3. Break-even Analysis (Break-even prices) ……………………………......... 75

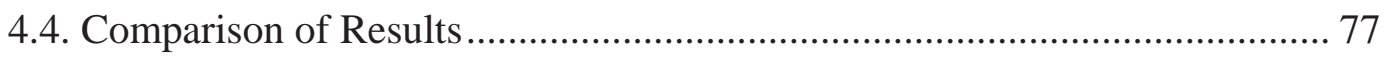

5. Discussion of Results ........................................................................................................ 83

6. Conclusions ............................................................................................................................. 89

7. References ......................................................................................................................... 93 


\section{List of Figures}

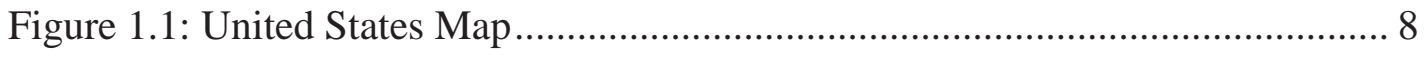

Figure 1.2: Location map of the Williston Basin ................................................... 9

Figure 2.1: Theoretical Production Curve ……………….................................... 15

Figure 2.2: WTI - Bakken crude oil differential between June 2011 - May 2013 ... 19

Figure 2.3: Clearbrook crude oil prices between May 2010 - May 2014................. 20

Figure 4.1: Production decline curve vs. annual oil production rates for the first

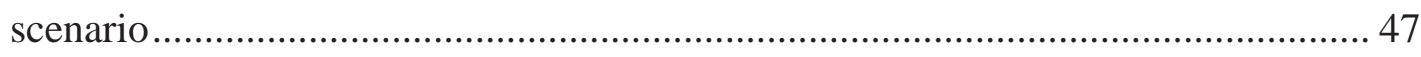

Figure 4.2: Annual oil production vs. EUR for the first scenario ............................. 48

Figure 4.3: Production decline curve for the second scenario.................................. 50

Figure 4.4: Annual oil production vs. EUR for second scenario............................... 50

Figure 4.5: 20 year production decline curve for the third scenario ......................... 51

Figure 4.6: Annual oil production vs. EUR for the third scenario ........................... 52

Figure 4.7: Production decline curve for the fourth scenario ..................................... 54

Figure 4.8: Annual oil production vs. EUR for the fourth scenario .......................... 54

Figure 4.9a: Cash flow statements for the first scenario years 0 through 4 ............. 57

Figure 4.9b: Cash flow statement for the first scenario for 5 years ......................... 58

Figure 4.10a: Cash flow statement between years 0 and 4 (second scenario) ......... 60

Figure 4.10b: Year 5 through 9 (second scenario) ..................................................... 61

Figure 4.10c: Cash flow statements for the second scenario covering 10 years ...... 62

Figure 4.11a: Cash flow statement between year 0 and 4 (third scenario)............... 64

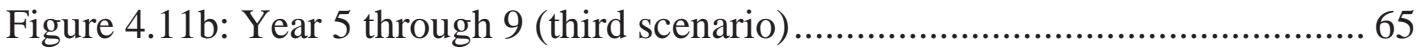




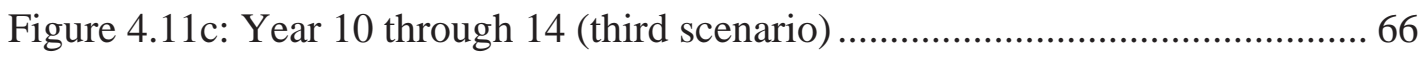

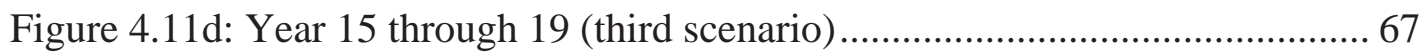

Figure 4.11e: Cash flow statements for the third scenario including 20 years......... 68

Figure 4.12a: Cash Flow statements between year 0 and 4 (fourth scenario) .......... 70

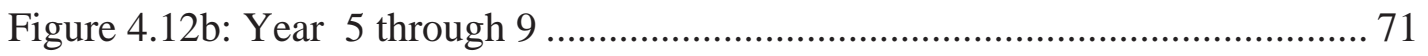

Figure 4.12c: Year 10 through 14, new well drilled in tenth year (fourth scenario) 72

Figure 4.12d: Year 15 through 19 (fourth scenario)......................................... 73

Figure 4.12e: Cash flow statements for the fourth scenario, including two wells ... 74

Figure 4.13:Sensitivity analysis for the best scenario (fourth scenario) ................. 81 


\section{List of Tables}

Table 2.1: Bakken Drilling Averages 2008 - 2013 .................................................. 13

Table 3.1: North Dakota Gross Oil Production Tax Allocation .................................. 35

Table 3.2: North Dakota Oil Extraction Tax Allocation .......................................... 35

Table 3.3: U.S. Federal Income Tax Rate Schedule................................................ 36

Table 3.4: 7-years MACRS Depreciation ............................................................... 39

Table 4.1: Initial input values for the hyperbolic curve ......................................... 45

Table 4.2: Input values for the simulated Bakken Well ........................................... 56

Table 4.3: NPV, IRR, and EUR results for the first scenario.................................... 59

Table 4.4: NPV, IRR, and EUR results for the second scenario ............................... 63

Table 4.5: NPV, IRR, and EUR results for the third scenario.................................. 69

Table 4.6: NPV, IRR, and EUR results for the fourth scenario ............................... 75

Table 4.7: Break-even prices for the scenarios .................................................... 76

Table 4.8: Initial input values for a simulated well .................................................. 77

Table 4.9: Comparison of results based on the cash flow statements ...................... 78

Table 4.10: Changes in NPV by drilling cost change ………................................ 79

Table 4.11: Changes in the NPV by oil price change................................................ 80

Table 4.12: Changes in the NPV by production rate change .................................. 80

Table 4.13: Changes in the NPV by royalty rate change ........................................ 80

Table 4.14: Changes in the NPV by LOE change …………………....................... 81

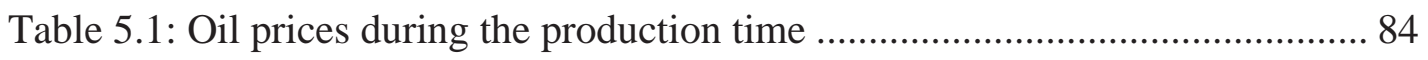

Table 5.2: NPV and IRR changes with constant oil prices ...................................... 84 
Table 5.3: Changes in NPV and IRR with increased lease operating expenses....... 86

Table 5.4: Nominal Annual Decline Rates for the simulated Bakken Well............. 87 


\section{Abstract}

Increases in oil prices after the economic recession have been surprising for domestic oil production in the United States since the beginning of 2009. Not only did the conventional oil extraction increase, but unconventional oil production and exploration also improved greatly with the favorable economic conditions. This favorable economy encourages companies to invest in new reservoirs and technological developments. Recently, enhanced drilling techniques including hydraulic fracturing and horizontal drilling have been supporting the domestic economy by way of unconventional shale and tight oil from various U.S. locations. One of the main contributors to this oil boom is the unconventional oil production from the North Dakota Bakken field. Horizontal drilling has increased oil production in the Bakken field, but the economic issues of unconventional oil extraction are still debatable due to volatile oil prices, high decline rates of production, a limited production period, high production costs, and lack of transportation. The economic profitability and viability of the unconventional oil play in the North Dakota Bakken was tested with an economic analysis of average Bakken unconventional well features. Scenario analysis demonstrated that a typical North Dakota Bakken unconventional oil well is profitable and viable as shown by three financial metrics; net present value, internal rate of return, and break-even prices. 


\section{Introduction \& Background}

\subsection{Introduction}

The US oil supply has been substantially rising for the last 5-6 years because of new exploration and production from various sources such as conventional reservoirs, tar sands, tight oil formations, and unconventional oil production from the shale deposits that were not previously considered as the main target reservoirs. Since the beginning of the year 2009, domestic crude oil production has been trending upward in the United States as a result of the steady enhancements in drilling techniques, and these developments also decrease the completion costs.

After a peak oil in 1970, the American oil production began to decline. Most of the giant sized oil fields were discovered in the United States and production was declining. Producers were unable to offset the rising oil demand with new exploration and development. However, a considerable oil demand decline occurred in the 2007-08 recession. But after the recession, oil price significantly increased from $\$ 39$ to $\$ 102$ per barrel between February 2009 and May 2014 associated with demand (Energy Information Administration 2014). High demand for oil with high oil price motivated the American operators to focus on new fields and explore new reservoir formations by using unconventional methods. Companies began to concentrate on new fields such as tight oil sands and shale reservoirs because the largest oil fields in the United States were discovered previously and oil production was declining from these fields. Hydraulic fracturing gained importance with technical developments. In reality, hydraulic fracturing was known from 1949. 
However, the economic conditions did not provide a profitable environment for fracturing until the 2000s because the cost of fracturing was much higher than drilling a new well.

The production from new fields by fracturing horizontal holes started to increase domestic oil production in the United States and the International Energy Agency (IEA) forecasters emphasized that the US was on the way to surpass Russia and Saudi Arabia to become the largest crude oil producer globally in 2020 (Bloomberg 2012). And just a few months later, IEA's 2013 forecasts shortened this period and pointed out the phenomenon would drive the US to become the biggest producer 5 years before the previous IEA estimates with the help of technical improvements and the great oil support from the unconventional oil flows, especially from Texas and the Williston Basin, Bakken Fields (Bloomberg 2013). Unexpectedly, a recent update has been declared by the IEA and they heralded that the US has already surpassed other countries and producing more than 11 million barrels of crude oil per day including liquids separated from natural gas (Smith 2014).

It is obvious that developments in oil production seem much faster now than in the last decade, but it is still not clear that the United States will hold its production position. Even though the annual domestic oil production has increased year by year after 2008, annual US petroleum consumption is still much higher than production, thus demanding oil from exporter countries. In 2012, US oil consumption was equal to 18.49 million barrels per day, but domestic demand has 
continued to decline year by year because the natural gas industry substituted for oil use and decreased the oil consumption in heating and electric generation sectors. (Annual Energy Outlook 2014). The transportation industry consumes the largest share of oil products, accounting for 70.42 percent of the annual consumption in 2012 (Annual Energy Outlook 2014).

From the point of view of economics, high taxation and new regulations to decrease petroleum consumption will not significantly induce consumers to give up consuming oil in the short term. Consumer demand for crude oil is different from and more essential than many other goods and products. High negotiated reference prices by suppliers cannot be elastic in the short run, especially for transportation and oil based chemical industries because it is not economic to substitute for oil with other products. It is clear that the use of renewable energy sources will not dominate the vehicle industry in the near future because of the infrastructural problems and new efficient gas and diesel vehicles. Therefore, new exploration and high production rates are very crucial to meet future demands.

As mentioned above, hydraulic fracturing gained importance in the first decade of the $21^{\text {st }}$ century as a result of developing technology and increasing oil price. It is one of the most effective ways to produce a reservoir. Previously, it was unprofitable to apply the unconventional drilling techniques. The cost of unconventional drilling including hydraulic fracturing was very expensive, and did not deliver profitable results for the investors. Then, in the early 2000 s, operators started to use hydraulic fracturing in shale reservoirs (both in oil and gas 
operations), which were not mainly considered as profitable reservoirs. Operations gave profitable results in unconventional shale oil and shale gas fields such as Marcellus Shale, Eagle Ford, and Barnett Shale. This phenomenon motivated and influenced investors in many locations. The Bakken Field - Three Forks Formation of the Williston Basin is one of the examples for this trend.

The North Dakota Bakken Field is one of the most productive oilfields for the US since 2007 because of unconventional operations. North Dakota drilling operations first started in 1951, but never had a great impact on the US oil market until 2009. High oil prices and high demand for crude oil made unconventional oil investments more attractive in the Bakken Field and triggered local investors and the small \& medium - sized oil companies to invest in the shale deposits. EOG Resources Company's drilling operations is the main operator in the area. Oil extraction from the Bakken will be an important case study associated with the beneficial utilization of oil because it creates numerous job opportunities and increases state income because of royalty fees and taxes from oil extraction. Moreover, current results state that unconventional oil production makes the Bakken field the second largest oil field in the US after Alaska's Prudhoe Bay (Mason 2012a). In the month of April 2014, oil production reached 1,001,149 barrels per day (Wegmann 2014).

On the other hand, the Bakken Field can still be assumed to be a new basin for investment. Current circumstances imply that some issues associated with 
unconventional oil economics will obstruct the investments of the major oil companies in the future. These concerns are explained in chapter 2.

This study encompasses a comprehensive economic analysis of the North Dakota Bakken unconventional oil plays and will determine whether or not producers are able to produce more profitable oil with recent market conditions (mid-2014) by using typical well profiles for 5 year, 10 year, and 20 year investment plans. Different scenarios and well simulations were implemented to assess the Bakken Field unconventional oil plays' overall profitability, economic viability, the impact of decline rates by using initial production (IP) rates, cost variables, and other input values. To calculate the profitability of these scenarios, three decision making financial metrics were used; Net Present Value (NPV), Internal Rate of Return (IRR), and break-even prices. Environmental and social costs related to hydraulic fracturing were partially avoided for the financial calculations, but mentioned in the next chapters.

For the purpose of this analysis, previous studies are examined. James Mason's studies related to the North Dakota Bakken are the main reason to focus on the area because Mason points out the huge oil potential of North Dakota and the peak oil issues for the next years (Mason 2012a) (Mason 2012b). In addition, the United States Geological Survey (USGS) oil assessment reports has been changing almost every year that enhances undiscovered oil potential and increases the curiosity on the Bakken area (USGS 2013). Also, Harvard Kennedy School's shale oil boom report and annual reports of the companies gave the main idea for the 
economic analysis (Maugeri 2013). Therefore, this study focuses on the profitability of unconventional oil investment in North Dakota with current market conditions (mid-2014).

This analysis concentrated on the current factors, Society of Petroleum Engineers (SPE) formulations and recommended decline curve parameters, cost variables, taxation, and state regulations that were active in June 2014 (mid-2014) and will be active for the next few years.

\subsection{Background}

Initial oil was drilled in 1859 by Edward Colonel Drake in Titusville, Pennsylvania. Within 155 years from 1859 to 2014, numerous inventions and innovations occurred in the oil and gas industries. Oil first gained importance when coal steam engines converted into oil based engines in the late 1800s. The United States began importing oil in the early 1950s. The biggest global oil crisis appeared in the 1970s. The 1973 crisis hampered the US global oil hegemony because of the Arab-Israeli War. Not only did production decline, but also the oil price increased extremely between 1973 and 1985 since OPEC initiated control of the upstream markets, which squeezed the American domestic market and hindered the US economy with shortages of petroleum products.

US oil production was declining after the 1970s. Crude oil production peaked in 1970 at 9.64 million barrels per day, and then fluctuated many years until the end of 2008 (Oil and Energy Trends 2012).Until the end of the first decade of 
the millennium century, most of the giant oil fields were already discovered in the US; proved oil reserves of the United States and its domestic production were both declining. The internal oil supply was not able to meet domestic consumption. In 2008, the US economy went into a big recession with the mortgage crisis, oil prices rose from 2003 to 2008, and as a result, the United States paid additional billions of dollars for external oil supply imported from Canada, Mexico, and other countries in the recession period. These issues impacted the economic plans of oil management. On the other hand, the US responded to this recession by decreasing oil consumption, but it was not enough to decrease the prices since consumption was so much higher than the domestic supply.

Recent statistics show that US domestic oil production has been steadily increasing since 2009. The year 2008 was the lowest production level for the American crude oil industry at 5.0 million barrels per day since 1946 (Oil and Energy Trends 2012). Recently, the domestic production increase has been due to new production from the Gulf of Mexico offshore wells and the unconventional oil production boom from shale deposits. Unconventional drilling and shale oil extraction are relatively new trends for the U.S., and the dynamics of the oil industry started to change with the improvements in these techniques. These technical improvements, high oil prices, and declining costs of production have made investment more feasible than in the last decade, and this has been the main reason for the oil boom around the Bakken area since 2008. Major American oil companies work in the Bakken Field, which is also known as the Williston Basin. 
The Williston Basin is in Montana, North Dakota, South Dakota, Manitoba

(Canada), and Saskatchewan (Canada). North Dakota and Bakken Formation,

Williston Basin are shown in Figure 1.1 and Figure 1.2.

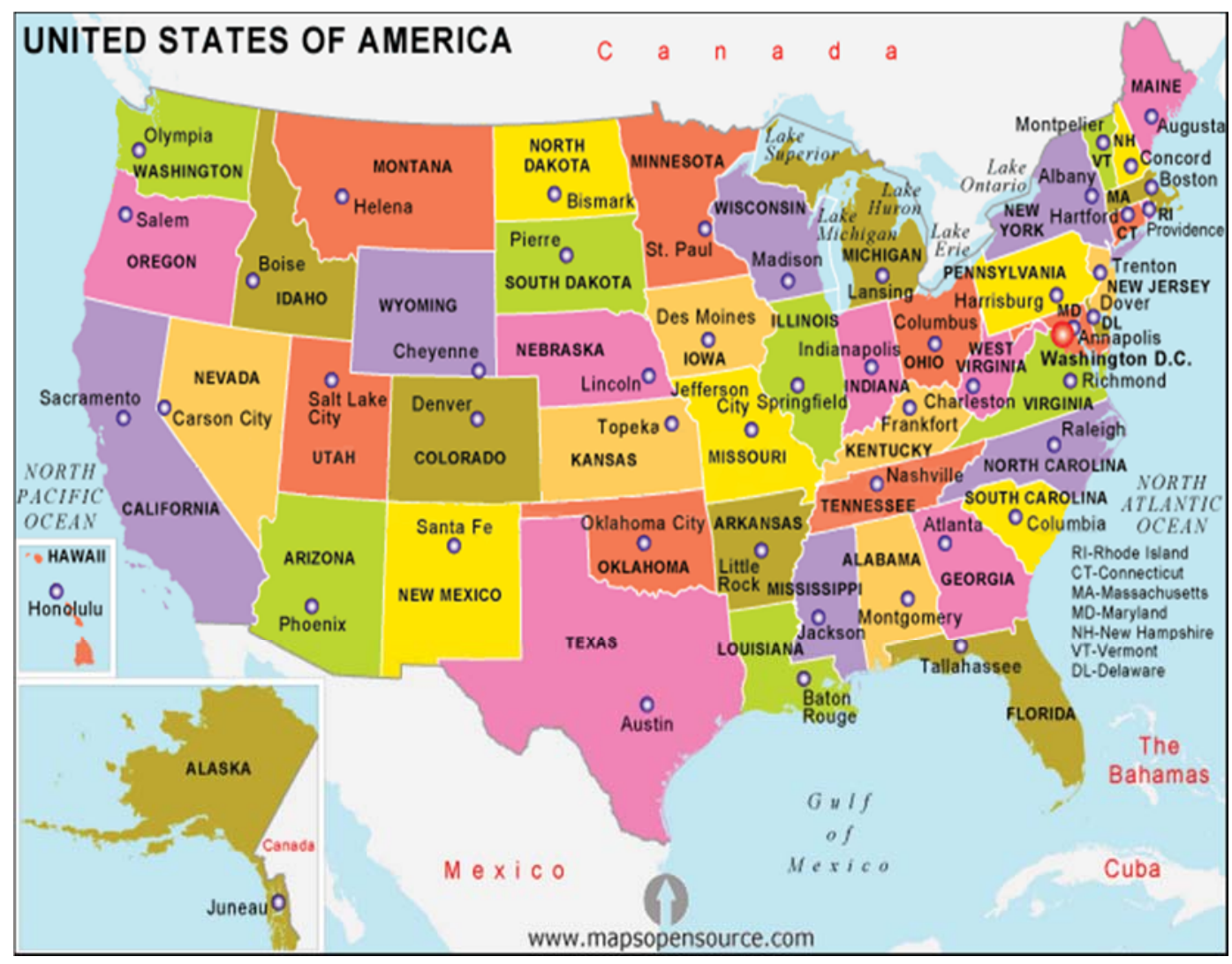

Figure 1.1: United States Map 


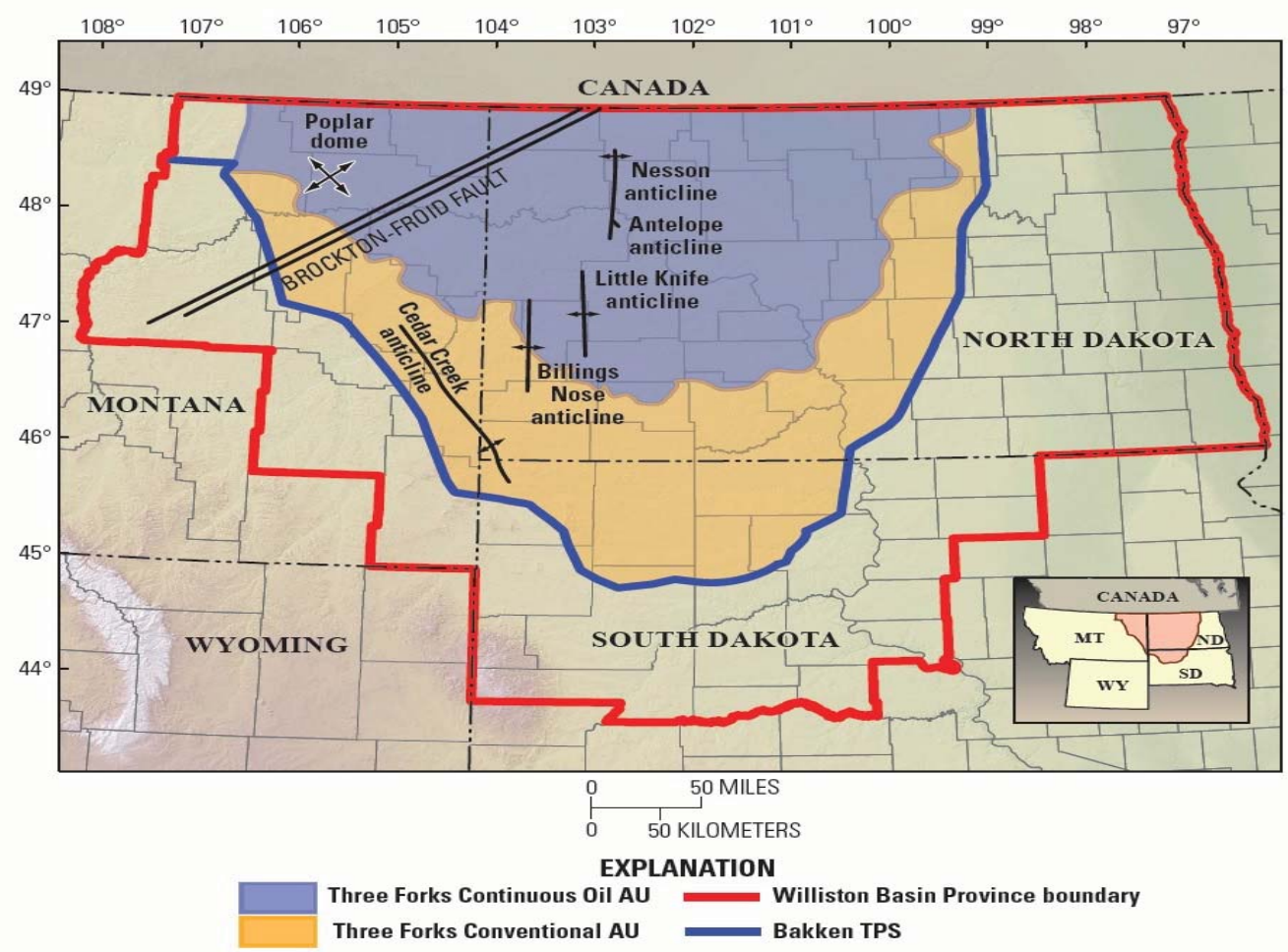

Figure 1.2: Location map of the Williston Basin, Bakken Field (USGS 2013)

Hydraulic fracturing is a well-known process in drilling industry that is used for producing oil from unconventional reservoirs. Hydraulic fracturing triggers wells drilled into tight sands, shale formations, and coal bed methane formations that have low permeability and poor flow rate. They started to become profitable and affordable in North Dakota within the last decade, but previously they gave profitable results in other fields such as Marcellus Shale, Barnett Shale, and Eagle Ford. The combination of hydraulic fracturing and horizontal drilling made North Dakota oil investment profitable (and almost all other unconventional plays in the 
world). Recently, more than 70 percent of North Dakota oil is supplied by unconventional resources (North Dakota DMR 2014).

The hydraulic fracturing or fracking is different from the previously drilled wells, which were drilled and completed in conventional way. The fracking happens after a well drilled and casing pipes has been settled in well bore (Earthworks 2014). The casing is perforated in the target zones that include oil and the fracturing fluid is injected into the target zones through the perforations. Because of the high pressure shale rock cannot protect its own form and starts cracking. By this way, the fracturing fluids and chemicals start to flow back to ground. The proppant materials remain in the target zones to keep the fractured zones open (Earthworks 2014).

Extraction from shale deposits by way of fracturing methods has a significant role in the oil market, and also help support the United States economy with considerable earnings. Current circumstances permit companies to invest in the basin, and high profits allure operators. After the production boom, the Bakken Field has become the second biggest oil field in the United States.

This study covers the North Dakota lands of the Williston Basin, hereafter called the "North Dakota Bakken", and concentrates on the state of North Dakota, Bakken Field unconventional oil plays by simulating a typical well, and including the state regulations. 


\section{Economic and Environmental Issues linked with Unconventional}

\section{Oil Production}

It is difficult to claim that all unconventional oil investments will be feasible and profitable in the long run. In other words, production from unconventional reservoirs do not always show feasible results to provide the economic viability of investments in the long run. Especially for the Bakken shale oil play, the economic viability is not sufficiently clear ever since shale oil operations began in 2007. Many economic issues will remain for decades.

Currently, the cost of unconventional drilling is much higher than conventional because the drilling operations include directional drilling and fracturing stage, they require additional equity investment. Horizontal drilling equipment are slightly different from the conventional ones. It requires additional special rotational devices and control systems for horizontal / lateral drill movements. Furthermore, hydraulic fracturing operations use large quantities of high pressure water, and water resources are not abundant in all locations. Operators also use fine grained sands and other chemicals to fracture and dissolve the rock.

Economic concerns are compounded by the volatility effect of oil prices, the uncertainty of EUR (estimated or expected ultimate recovery of oil), high production costs of directional drilling and hydraulic fracturing, sharp production decline rates, and potential production from conventional fields that will provide competing adequate oil into the market. These issues are all linked to each other and will impact an investment's profitability in the North Dakota Bakken Field. This 
study includes the current production data (mid-2014) and indicates updated market conditions (mid-2014) and evaluates them based on the concerns mentioned above.

\subsection{Unconventional Production Cost}

Production costs include drilling and well completion costs together (D \& C costs). Geological factors are the main factors for production costs, for example, shale formations include clay materials. Clay zones are sticky and may swell with water contact. Most of the drill string stuck problems occur in these formations. Thus, these issues increase drilling costs.

The cost of conventional oil wells are less than unconventional oil wells because the horizontal drilling and fracturing stages bring new operations and additional costs into the system. Each stage of the hydraulic fracturing and completion costs are about $\$ 95,000$ in the North Dakota Bakken. Each unconventional operations contain approximately 40 - 50 fracking stages, which costs around $\$ 3.8$ million to $\$ 4.75$ million (Siegel 2013). In addition to this, a regular unconventional drilling cost will be between $\$ 4$ million and $\$ 5$ million. Horizontal drilling and hydraulic fracturing sections roughly account for half of the total production costs. According to the Hess Oil Company, total production cost of a well decreased to $\$ 8.6$ million at the end of 2013 , which was $\$ 13.4$ million before (Dukes 2013a). A \$4.8 million difference is associated with the advanced drilling technologies including high - tech equipment. In contrast to this, a simple 10-stage fracking operation for 5,000 foot lateral drilling was around $\$ 500,000$, and the total 
well completion was equal to $\$ 1$ million to $\$ 1.5$ million five years ago (Siegel 2013). Recent operations cover 10 to 15 thousand feet of lateral operations; therefore, the cost of drilling is much higher than conventional drilling.

In the last five years, the Bakken Field unconventional operations rapidly expanded, drilling periods shortened from 32 days to 18 days, and lateral reservoir development doubled from 5,000 feet to 10,000 feet to allow more fracking stages (North Dakota DMR 2013). Advanced technology decreased the total cost of production and provided significant improvements in the unconventional oil production, increasing from $77 \mathrm{bbls}$. / day to $130 \mathrm{bbls}$. / day per well.

Table 2.1: Bakken Drilling Averages from 2008 to 2013 (North Dakota DMR 2013)

\begin{tabular}{|c|c|c|}
\hline Bakken Drilling Averages & End of 2008 & End of 2013 \\
\hline Well Lateral Length & $5,000 \mathrm{ft}$. & $10,000 \mathrm{ft}$. \\
\hline Well Total Depth (TD) & $16,000 \mathrm{ft}$. & $21,000 \mathrm{ft}$. \\
\hline Average Prod. Per Well (bbls./day) & 77 & 130 \\
\hline Drilling Period Per Well & 32 days & 18 days \\
\hline
\end{tabular}

On the other hand, other costs of production comprising labor, drilling supplies (water, chemicals etc.), and drill strings rise each year due to inflation. Between 2002 and 2008, average lease operating costs increased by around 60\% 65\% (Annual Energy Outlook 2010). Moreover, due to drilling intensity, well saturation will occur in the future, which has a negative impact on total production 
and production declines will begin. For that reason, if oil price decreases in the near future and falls under the break-even price, these production costs will obstruct possible investments since they cannot exceed the net investment hurdle rates.

\subsection{Production Decline Rates}

The declining production rate of a well is one of the most important issues for decision makers because oil is a depletable and a non - renewable resource. As learned from previous studies and well reports, well production rates do not go upward for a long period of time after the initial production, declines day by day because of the formation quality such as porosity and permeability rates, well pressure, and some other reservoir features.

Production rates are crucial for the economic evaluation of the unconventional plays. Due to the low permeability and low porosity characteristics of shale deposits, production rates will vary and will be relatively lower than conventional production rates over the long term. Expected ultimate recovery (EUR) values will change quickly from the original estimates because of changes in the initial production (IP) rates and production decline rates. Three different traditional decline curve analysis formulas are applicable for oil and gas wells: exponential, harmonic, and hyperbolic curves. These formulations rely on the initial production rates (IP) and nominal decline rates (percent per year). 


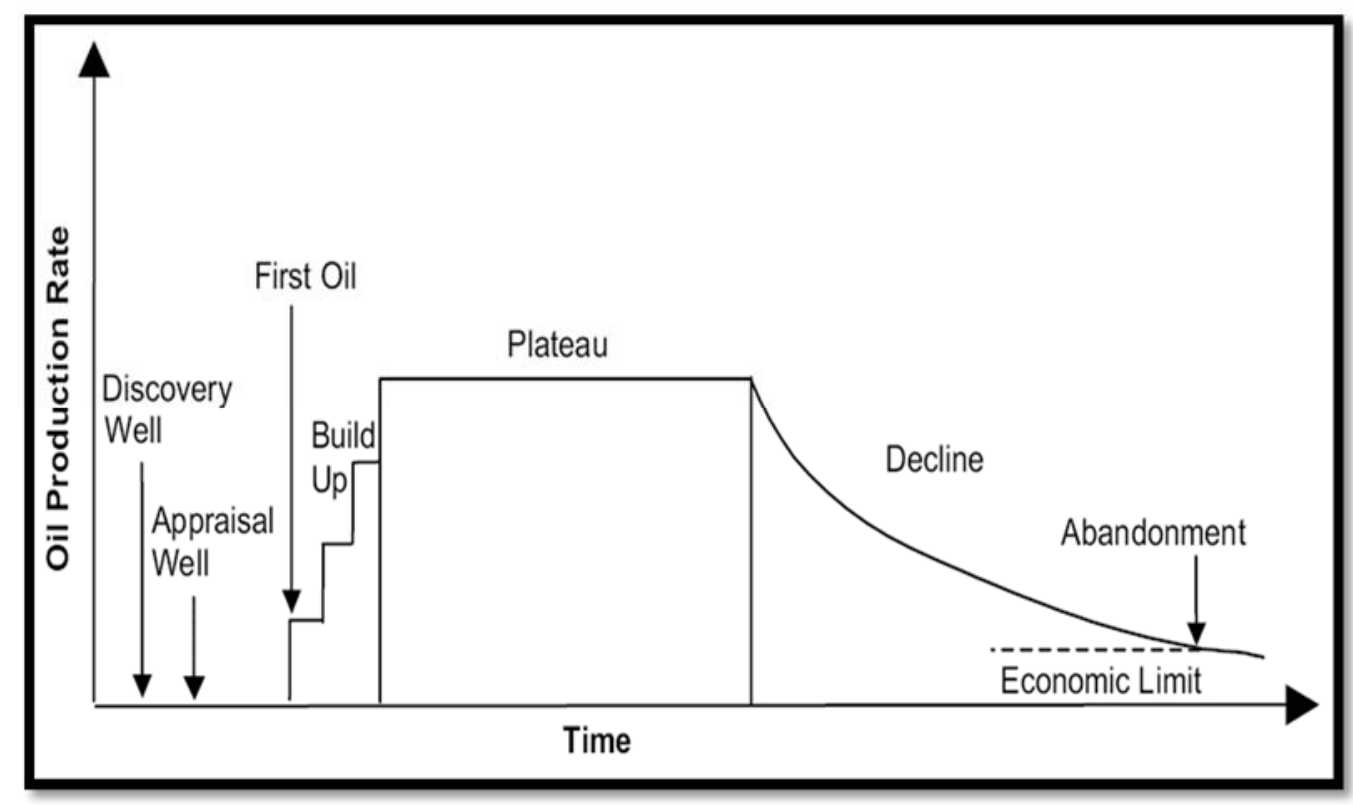

Figure 2.1: Theoretical Production Curve (Davies 2001) and (Robelius 2007)

Figure 2.1 shows that the initial production steadily rises up to a plateau level with work overs and well stimulations but then the high production rate starts to decline. In some cases, an economic limit exists in the first years of the well-life. Most of the giant sized oil fields were discovered in the twentieth century and most of them exceeded their plateau levels, but global oil production was declining before the unconventional hegemony. High consumption rates and high oil prices motivated investors to seek new field discoveries and technical improvements in drilling.

Unconventional resource management is trying to minimize the total costs, searching for the most cost efficient ways with high-tech solutions. Mr. David Hughes, from the Post Carbon Institute, released a report about unconventional reservoirs, encompassing several plays studying many production decline rates, 
demonstrating that unconventional fields decline much faster than conventional fields after the initial production (Hughes 2013).

The North Dakota Bakken Field is a new shale oil boom for the United States, but very interestingly Deborah Rogers published an article in Energy Policy Forum, and alleged that the daily oil production per well in the North Dakota Bakken shale oil plays peaked in 2010 (Rogers 2013). Furthermore, James Mason underlined the short term investment boom in the Bakken and pointed out the drilling intensity of the region (Mason 2012b). As opposed to Rogers's study, Bakken oil production per well increased to 144 bbls. / day level in June 2012 (Patterson 2013). In contrast to James Mason's approach, some companies are planning to use re-fracking / re-stimulation technologies to improve their production rates after 10 to 20 years of the initial well activity. Bakken Field's oil peak issue is still open, but February 2014 results (126 bbls. / day per well) show that the production rate per well has been decreasing for almost two years (North Dakota DMR 2014).

Annual production decreases impact the annual revenue for both the state government and investors because when profits go down, royalty payments and other taxes also decrease. The profitability of a well is basically associated with IP rates and decline rates. Companies will shut down their production at some point when the economic limit occurs. Therefore, most of the operators desire short term contracts rather than long term ones and depending on the EUR values, an 
investment will easily shift from positive to negative profitability in the long run if production greatly decreases.

On the other hand, as mentioned before, producers are able to improve their revenues by well maintenance and re-fracking. But, these additional operations increase the total drilling cost by 2-4 million dollars which accounts for 40 to 60 percent of total well completion costs (Hefley et al. 2011). However, these stimulations will not reach the initial production levels and will begin to decline after a short time. That is why, Bakken operators generally prefer drilling new wells instead of re-fracturing since not all the re-stimulation costs reach break-even levels.

\subsection{Oil Price Volatility, Transportation and Refinery Issues}

Another economic issue related to shale oil production is oil price volatility. Oil can be assumed to be a global market because it relies on demand and supply changes anywhere in the world. But local oil prices may easily fluctuate with regional impacts. As opposed to other market commodities, or a single reference price, negotiable oil prices will vary globally. For instance, in the Middle East, economic and political conflicts will directly impact oil prices and oil supply quickly, like the recent Iraq case. Or, unexpected oil supplies from other Canadian fields will alter the regional contract prices in the Alberta area. Additionally, the case of the 1973 crisis was the pioneer of the volatile prices.

Besides two well known (Brent and West Texas Intermediate (WTI)) spot prices, Bakken Blend ex - Clearbrook and Bakken Blend ex - Guernsey are the 
benchmark prices for the North Dakota Bakken crude oil market. These prices got their names from their pipeline junction areas, and the Clearbrook price is the main price indicator for this project since most of the forecasters focus on the Clearbrook price and it is considered as the main price for Bakken shale oil by Platts, which is the only publisher of the local oil prices.

The Clearbrook spot price is the price for Bakken crude oil including the transportation cost between North Dakota and the pipeline junction location at Clearbrook, MN. Thus, the price of Clearbrook crude oil can be considered as the price at a Bakken well - head price plus transportation fees. The Clearbrook price is a regional benchmark and slightly lower than Brent and WTI prices. The spread or premium between these prices and Clearbrook depends on many factors. First of all, North Dakota Bakken producers consider the transportation costs; that is why, they discount their prices to be competitive. These discounted prices will be assumed as an opportunity to get involved in the local oil market, but the price differential will also limit long term investment. Lack of infrastructure for transportation and refinery issues in North Dakota significantly affected Clearbrook prices in 2011 and in early 2012. The spread between WTI and Clearbrook even exceeded $\$ 28$ in early 2012 (Energy Information Administration 2013).

Pipelines are considered as the most cost - effective way to transport crude oil in the United States, but it is also relatively expensive to construct them rather than building the other shipping options; and pipeline construction may encounter the regulation problems (Annual Energy Outlook 2013). 


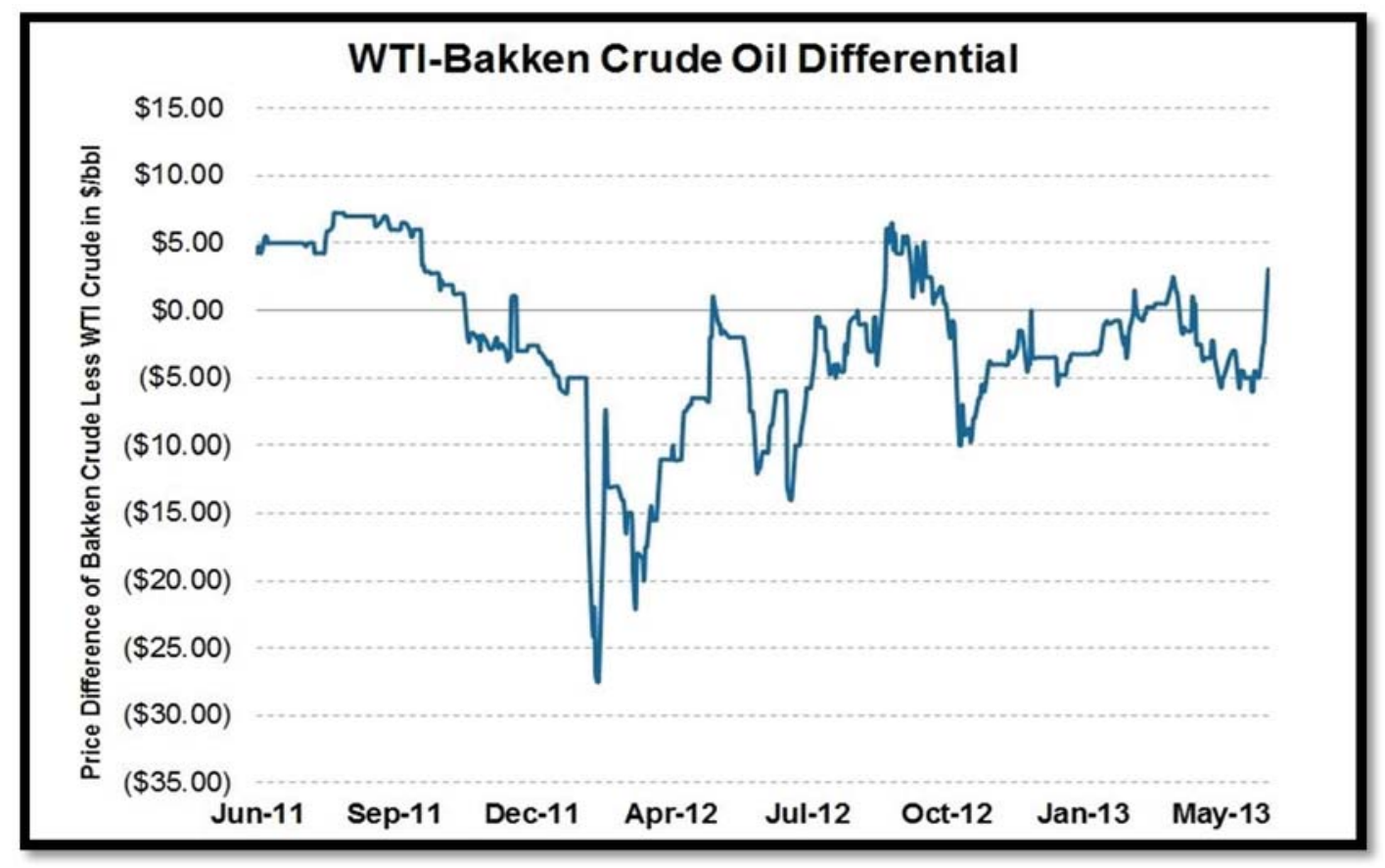

Figure 2.2: WTI - Bakken crude oil price differential between June - 2011 and May $-2013(\operatorname{Pan} 2013)$

After the production boom of 2011 and 2012, North Dakota and its neighbor states initiated improvements in oil transportation. Figure 2.2 shows that the developments in transportation helped to narrow the spread between Clearbrook and WTI in the first half of 2012 (Pan 2013). Current rail capacity even let operators sell their oil to the East and the West Coasts. However, they cannot ignore transportation costs in short term contracts because it is an important cost. It is also an important variable for future assessments. 


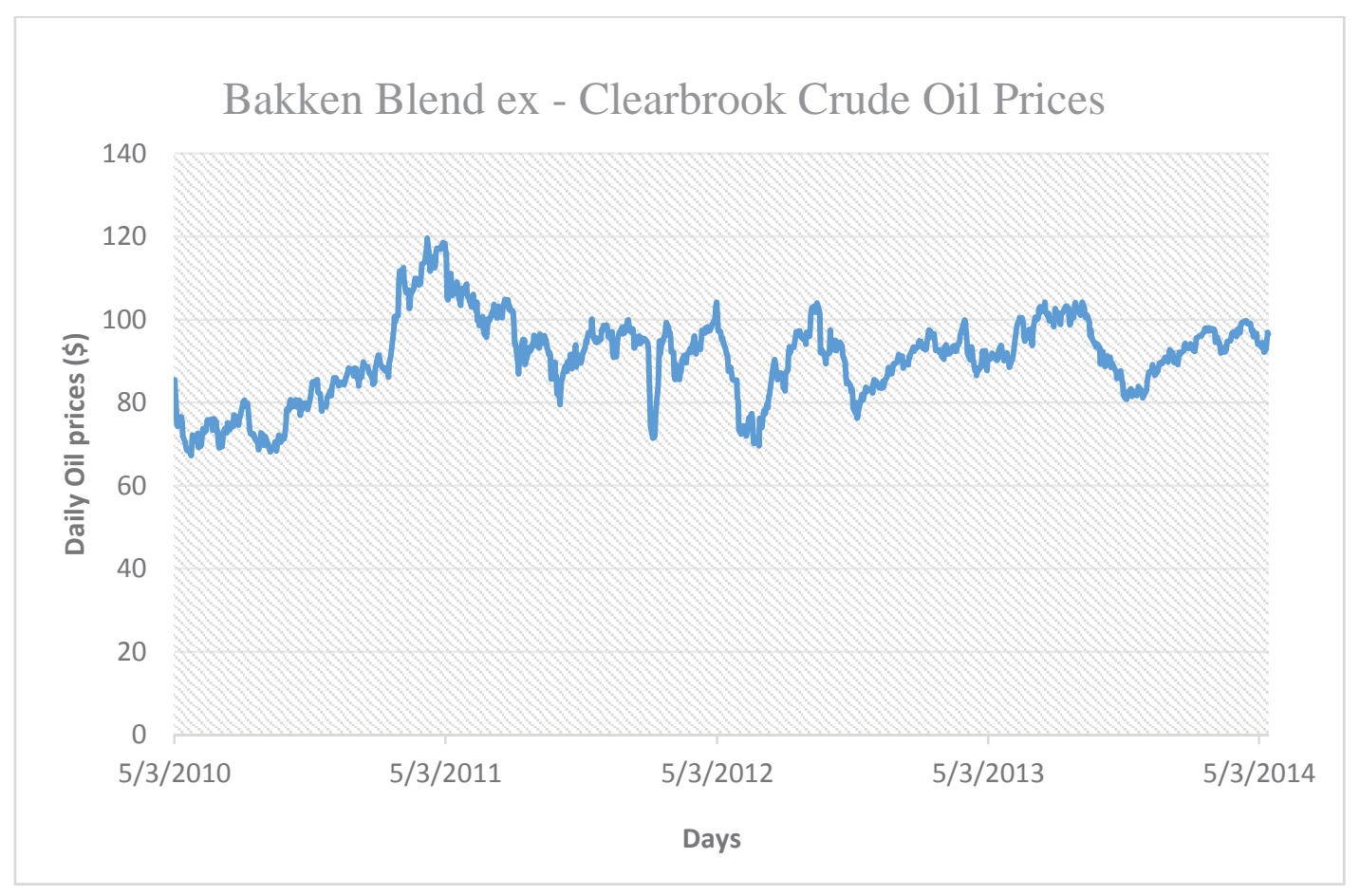

Figure 2.3: Clearbrook crude oil prices between May 2010 and May 2014 (Platts)

Figure 2.3 presents the Bakken Blend ex - Clearbrook crude oil price for the last 4 years. Not only do infrastructure and transportation influence the oil price in North Dakota, but also some other factors determine price fluctuations. One of them is competitive oil prices. Enhanced railroads and pipeline capacities allow North Dakota to increase oil production, but similarly, Canadian crude oil production was encouraged to boom. Canadians compete with Bakken oil and try to keep their prices lower than the Bakken crude price, which will be much more attractive for buyers. There will be a WTI - Bakken spread along with fluctuations, and additionally this will decrease the revenues for both investors and state governments. One other thing that will alter price is the unexpected oil supply from 
the Bakken Field. Unpredicted warm weather conditions will stimulate high production and result in a seasonal oil surplus. That was one of the main reasons of the \$26.50 spread between Clearbrook and WTI prices in 2012 (Pan 2013).

Recently, the WTI - Clearbrook spread is much lower due to improvements in transportation and enhanced pipeline capacity. However, volatility of Clearbrook prices will remain an issue for both sellers and buyers. In addition, predicted future declines will increase price concerns.

\subsection{Environmental and Social Concerns}

Unconventional oil production will have environmental costs and concerns. These external costs may increase the total cost. Environmental issues may obstruct the probable investments, but may also cause irrecoverable environmental damage. Most of the Bakken operators try to minimize external costs by updating their environmental policies with the help of advancing technical progress.

Hydraulic fracturing is a completion phase of horizontal drilling and stimulates the largest environmental concern. Hydraulic fracturing operations may damage water resources, including both surface supplies and underground aquifers. In addition to this, poorly planned well construction or antiquated processes can leak fracking materials into the casing layers and cements, which may result in possible aquifer contamination (Gresh 2011). Water contamination hinders the effective use of agricultural resources. Therefore, water management is a crucial issue. Drilling operations periodically need thousands to millions of gallons of 
water. An average North Dakota well uses about two million gallons of water (equal to 7.6 million liters) and predicted water demand for total oil operations of the Bakken field is 27.6 billion liters, which is for hydro-fracking (Shaver 2012). The North Dakota Bakken is drier area than the Marcellus Shale or the Barnett Shale. For that reason, the allocation of water resources is much more critical than in other locations. Drilling intensity rises year by year in the North Dakota Bakken as a result of the steep production declines of $50 \%$ to $80 \%$ of the initial production in the second year. Thus, operators drill more wells to mitigate these decline rates. Increasing drilling intensity means more water used, more environmental concerns, and more regulations.

Waste water disposal is another concern under the issue of water management. Approximately $10 \%$ to $40 \%$ of injected water flows back to the surface during the well completion (Stepan et al. 2010) and (Galusky 2011). This flow back water will include dissolved minerals and naturally occurring radioactive metals (NORM) and other chemicals that are used in hydraulic fracturing. Most of the Bakken operators can re - cycle $80 \%$ to $90 \%$ of waste water and inject it into other well operations. Either storing or transporting the water will contain some risk for North Dakota. A leakage to freshwater can substantially impact the local ecosystem. Also, based on the Ohio case, the deep - well underground injection of this wastewater could trigger small earthquakes (Ohio DNR 2012).

Besides these issues related to water contamination, flaring of natural gas can occur from Bakken oil wells due to lack of gas pipeline infrastructure. North 
Dakota is an isolated area when compared to Pennsylvania or Texas, and lack of infrastructure prevents the storage or use of abundant quantities of natural gas. It is too costly to store and transport natural gas without pipelines, thus operators flare gas during drilling and work over phases, which causes air pollution.

\subsection{Recent Bakken Operations}

The Bakken Field unconventional oil production, including Montana and North Dakota, reached the level of million barrels per day in April 2014. High oil prices, profitable returns on investments, declining costs of production, technological improvements with horizontal drilling, and taxation incentives facilitated the production boom. On the other hand, because of the steep production declines after the initial years, new wells are continually drilled to mitigate the decline effect. This increases drilling intensity; affecting other uses for the land. Although the state government updates regulations on water management, water contamination issues remain active.

All these conditions and concerns are very important for the North Dakota Bakken operators, landowners, and employees. Even slight changes will impact economics of oil investments and will either increase investments or lead to shut downs. Economic viability is the most essential issue for short term and long term investment planning. The research question is: considering all these concerns along with market conditions (including lease rights, oil prices, and production rates) is it economically profitable to produce shale and tight oil from North Dakota Bakken 
wells? Based on 5, 10, and 20 year investment plans, are these unconventional oil wells economically viable? 


\section{Methodology}

The recent unconventional boom from the North Dakota Bakken has made an astonishing economic contribution to the United States economy (Annual Energy Outlook 2013). But, is it viable? Most of the scholars and society do not have an answer for how long this contribution will perpetuate. What if the oil prices go down? When will be the oil peak occur, or has it already occurred before? Should we consider the original oil in place (OIP), technically recoverable oil, or estimated ultimate recovery (EUR) for effective and more accurate economic evaluations? Which investment time span is better; short term investments of 5 years production, or long-term investments of 10 years, or more than 10 years?

To find answers to all these questions, this study concentrates on the recent unconventional oil production boom with the assistance of several economic indicators. Based on these indicators and cost variables, different scenarios are evaluated to decide whether investments are profitable or not. Production rates, decline curves, cost variables such as leasing fees and signing bonus payments, drilling and completion costs, and all other expenses are calculated and included in the cash flow statements for the economic estimations of the North Dakota Bakken unconventional oil play. Recent tax regulations were considered via North Dakota Red Book 2012. Bakken Blend ex - Clearbrook price is used in the cash flow statements as the reference oil price. Standard financial metrics were used in the scenarios to judge the profitability. To determine the upstream profitability and the feasibility; NPV, IRR, and break-even analysis (minimum return on investments) 
methods are applied for different well simulations. Any positive or negative cash flow statement are evaluated using the NPV method at 10 percent minimum acceptable rate of return (MARR). For the IRR method, a minimum hurdle rate for oil investments is 10 percent. Break-even prices are calculated to compare them with initial scenario prices. Some assumptions are based on the decision and financial analysts of North Dakota operator companies such as Continental Resources, Chesapeake Energy, Whiting Petroleum, and Hess Corporation; and the State of North Dakota, Department of Oil and Gas Division. The subsections of this chapter elaborate the elements of this research.

\subsection{North Dakota Bakken Unconventional Oil Prices}

Oil price is one of the main components of any financial assessment and one of the most essential inputs to determine profitability by comparing with break-even prices. The Bakken blend ex-Clearbrook price is used in this analysis based on communications with North Dakota Oil and Gas Division analysts and Platts reports. The last four years' average price is were used and is less than the recent Clearbrook price since Clearbrook prices fluctuated many times between May 2010 and May 2014 period (Figure 2.3).

Clearbrook price is for the sweet and light, less sulfur content Bakken unconventional oil, and includes the transportation fees between North Dakota and the Clearbrook, MN pipeline junction. The May 2014 well - head price varied 
between $\$ 88$ /bbl. and $\$ 90 / \mathrm{bbl}$. (Platts 2014). The last negotiated Clearbrook price for May 15, 2014 was $\$ 96.48$. Thus, a $\$ 5-6$ difference can be considered as the transportation fee. The starting price of $\$ 90.78$ per barrel was recorded as the average value for the last 4 years' Clearbrook price (May 2010 - May 2014).

The annual oil price increase is assumed to be the same as the projected economic growth rate, which is $2.8 \%$ per year for 2014 , from the International Monetary Fund (IMF World Economic Outlook 2014).

\subsection{Total Drilling and Completion Costs}

Total drilling costs comprise all drilling and well completion costs associated with an unconventional oil well before the initial production phase. It would be better to divide these costs into two groups as the drilling costs and the completion costs. The drilling costs include all the possible costs that operators spend during the drilling days such as equipment costs, additive fluid costs, mud costs, water supply costs, horizontal drilling costs, rig rents, etc. According to Bakken operators, this initial phase accounts for 50 to 70 percent of the total drilling costs, which ranges from $\$ 4.0$ million to $\$ 5.6$ million per well (Dukes 2013b). 60 percent is assumed for this study, thus the cost of the drilling phase is $\$ 4.8$ million. The second phase is the well completion. Well completion costs consist of mainly well stimulation works (hydraulic fracking), cementing, casing, perforation efforts, water supply and sand costs for fracking, and include some other well tests related to completion that must be done before the production stage. Well completion costs 
range from $\$ 2.4$ million to $\$ 4.0$ million per well, and it accounts for 30 to 50 percent of the total drilling costs. 40 percent is assumed for this analysis, so $\$ 3.2$ million is used According to Hess Corporation, Bakken Field unconventional oil drilling cost (D) per well was equal to $\$ 8.0$ million in the first quarter of 2012 , and $\$ 5.4$ million was the well completion cost (C) (Hess Corporation 2013). Technological developments, improvements in hydraulic fracturing, and water re-cycling all diminished completion costs significantly by the end of the second quarter of 2013 , and the total drilling cost (D \& C) shifted from \$13.4 million to \$8.4 million. Current average cost per well is slightly less than $\$ 8.4$ million. In this analysis, annual reports and other web materials were scanned, and $\$ 8.0$ million total cost per well is used based on the costs of the big players of Bakken Field such as Hess Corporation, Continental Resources, Whiting Petroleum, and Chesapeake Energy.

\subsection{Lease Agreements and Royalty Payments}

Part of the lease payments are assumed to be a sunk cost since companies do not directly record them under their cash flow statements (Dizard 2010). As opposed to this approach, the model used here includes all leasing costs to calculate the most complete results for the estimation of profitability.

The leasing process starts with an initial interest in the field. After the geological and geophysical surveys, companies decide to continue or give up their land operations. Legally, companies must sign a lease agreement with the 
landowners to gain access to the mineral rights before drilling begins. Furthermore, some of these ownership agreements must be done even before the geophysical seismic works phase that occurs after the field geology works (Anderson 2006)

Oil and gas leases are competitive. Landowners or their responsible attorneys negotiate the lease conditions with operator companies directly. Some residents of North Dakota such as in the western part are familiar with this process because petroleum companies have extracted oil from their territories for more than $30-40$ years. Interest in unconventional oil spread around the whole state and most of the North Dakota land areas became attractive for investors, but the residents of these new areas are not familiar with the system.

Lease costs are considered to be part of the pre - production (finding) costs and royalties are considered as part of the production (lifting) costs (Inkpen and Moffett 2011). Petroleum companies must offer royalty rates and lease bonus payments together directly as an incentive. The attorneys' or landowners' power of bargaining brings higher royalties and higher signing bonus payments. The royalty rate is an agreed upon percentage that is paid based on the total oil production, paid periodically. Royalty fees only become active after the onset of production. In North Dakota, royalty rates usually range from 6.25 percent to 18.75 percent, in some areas up to 20 percent. This rate is determined by negotiations as mentioned before, and each landowners' offer is different from others (Anderson 2006). A 12.5 percent royalty rate is assumed these cash flow statements, and this amount is subtracted from the gross revenue without including taxes and other costs. In addition to this, 
companies must also negotiate the signing bonus payments with landowners. This amount will vary depending on the estimated well productivity and the mutual negotiability. It was impossible to determine a fixed value for these bonus payments. For that reason, North Dakota oil and gas discussion forums were scanned, and a range found between a few dollars (roughly $\$ 50$ ) to $\$ 20,000$ per acre (Maugeri 2013). Thus, in this model, $\$ 3000$ per acre is used as the signing bonus payment.

Regardless of how many mineral acres are leased, any land that covers 160 acres must have its own individual lease (Anderson 2006). Additionally, 640 acres of land (one square mile) are required for a successful well drilling operation, which means 4 different oil leases are required for each drilling operation. But to keep this simple, the lease and royalty rates for all parcels are assumed to be constant. In this analysis, oil leases cover five years terms and every five years, leases will renew with the same assumed rates. Thus $\$ 3000$ per acre bonus payment $(\$ 1,920,000$ for 640 acres) and 12.5 percent royalty rates remain constant for each lease period, if the companies want to sign again.

\subsection{Production Rates}

To assess the economic profit and the economic viability, production rates and oil prices are the most critical variables. High oil production rates for a long term will reduce the payback period and increase the NPV. However, if the production rates decline too fast, an investment can turn unprofitable in a short 
period. Production rates cannot be flat or constant for a long period, and rates will dramatically change after the initial production (IP).

Oil production has been the main source of income for the oil giants for the past decades (Inkpen and Moffett 2011). Well productivity plays an important role in the cost management. Geological factors such as rock type and rock characteristics, depth, thickness, and properties of the hydrocarbon, and other factors such as well density, wellbore size, production method influence the production rates. Economic, political, and current market conditions also affect the production rate.

Tight oil and shale oil reservoirs contain less porosity and less permeability due to their geological attributes than sandstone and limestone reservoirs. For that reason, fracturing and horizontal drilling are essential for high production rates. The production data for this analysis was gathered via many companies and the probabilities of low, medium, and high well production rates are considered based on production reports. In this study, the probabilities of these three profiles were taken as respectively; $20 \%, 60 \%$, and $20 \%$. IP rates for these profiles in the Bakken Field are considered as respectively; 174 bbls. / day, 402 bbls. / day, and 652 bbls. / day. The expected production rate of a typical North Dakota Bakken well will be:

$$
\begin{gathered}
\text { Expected production value }(E P V)= \\
{[(174 * 0.2)+(402 * 0.6)+(652 * 0.2)]=406.4 \text { bbls. } / \text { day }}
\end{gathered}
$$


Thus, an assumption of the initial production value of 406 bbls. / day was considered for typical Bakken well in this study.

Decline curve analysis is an empirical statistical method of analyzing production performance during the well life. It assumes that the current well and reservoir conditions will remain unchanged in the future. Decline curves terminate when net revenue of production and production costs become equal. It is known as the economic limit or break-even and below this point, investment is unprofitable.

There are three traditional methods that developed by J. J. Arps (1944) can be used for the decline analysis equations: exponential, harmonic, and hyperbolic decline curve equations. These three methods are the most common ways of forecasting future production and estimating the EUR. The hyperbolic decline curve equation is used for the first years, then the declining trend reaches a constant decline percentage, and a stretched exponential decline curve equation is used until the end of the forecast. In the model of a hyperbolic decline curve, the data plots concave upward (Petrobjects 2004).

The formulation of the hyperbolic curve is:

$$
q_{t}=\frac{q_{i}}{\left(1+b d_{i} * t\right)^{\frac{1}{b}}}
$$

Where;

$\mathrm{q}=$ Production rate of the well at time $\mathrm{t}$, years

di: Initial nominal exponential decline rate $(\mathrm{t}=0)$, fraction / year

$\mathrm{q}_{\mathrm{i}}=$ Production rate of the well at time $0, \mathrm{t}=0$, barrel of oil per day (BOPD) 
b= Hyperbolic exponent of decline, $b$-factor, characterizes reservoir's production

decline

$\mathrm{t}=$ time $($ years $)$

Apart from the initial production rate, the other input variables for the hyperbolic curve equation were either picked from the operating company analysts and Bakken Consultant firms or relevant data gathered by way of scanning the previous and current forecasts. These numbers can vary for each type of study, but hyperbolic curve serves as an approximation for the production values at any chosen period.

After reaching the constant decline percentage, production vs. time will become a straight line. At this point, the hyperbolic curve shifts to the exponential curve, which assumes the $b$-factor zero $(b=0)$. This continues until the economic limit.

The formulation of the exponential decline curve is:

$$
q_{t}=q_{i} \frac{1}{\left(e^{d_{i} t}\right)}
$$

Referring to the EUR calculations, the economic limit can be reached at any time (profit will decrease to zero or become negative), and companies will decide to shut-down their operations to stop losing money or re-stimulate their wells to return to economic profitability. Hyperbolic and exponential decline curve assumptions are 
very important for the cash flow statements because the annual total production multiplied by the oil price per barrel determines the annual gross revenue.

\subsection{Taxation}

\subsubsection{North Dakota State Taxes}

Not only do the producers earn revenues from the production, but also the state government partially shares in these revenues. Taxes are the most important way to collect revenues and circulate it under the control of the state. For example, transportation and refinery issues have been the most crucial concerns for North Dakota after the unconventional boom. For that reason, state government decided to improve roads, schools, and other public infrastructure. Tax revenues funded these solutions for emerging concerns. Also, environmental costs might be offset with an efficient allocation of these revenues.

The North Dakota state government has different taxes on oil. The first tax is the gross oil production tax. A $5 \%$ flat rate is implemented on the gross value of all oil produced at a well, separate from the royalty fees (Fong 2012). 
Table 3.1: North Dakota Gross Oil Production Tax Allocation

\begin{tabular}{|l|l|}
\hline \multicolumn{2}{|c|}{ Allocation of 5\% Gross Production Tax } \\
\hline $45 \%$ & Counties (Infrastructure Funds) \\
\hline $35 \%$ & Schools \\
\hline $20 \%$ & Cities \\
\hline
\end{tabular}

The second one is the oil extraction tax, and it is charged on the extraction of oil from the earth. The oil extraction tax is $6.5 \%$ of the gross value of crude oil produced at the well (Fong 2012). In some specific conditions, this rate may be reduced to $4 \%$; but in this model, our simulated wells do not meet those requirements and do not have exemptions, so a $6.5 \%$ rate is applied.

Table 3.2: North Dakota Oil Extraction Tax Allocation

\begin{tabular}{|l|l|}
\hline \multicolumn{2}{|c|}{ Allocation of the Oil Extraction Tax } \\
\hline $30 \%$ & Legacy Fund \\
\hline $30 \%$ & State General Fund \\
\hline $20 \%$ & Education Purposes \\
\hline $20 \%$ & Water Resources Trust Fund \\
\hline
\end{tabular}

Thus, a $5 \%$ gross production tax and a $6.5 \%$ oil extraction taxes are charged by the North Dakota State Government. 


\subsubsection{Federal Income Tax}

After the state tax deductions, the federal corporate income tax is applied to revenue. The formula for the federal income tax is:

$$
\begin{gathered}
\text { Tax }=\text { Base amount }+ \text { Tax rate } *(\text { Federal Taxable Income } \\
- \text { Lower Value of Income Bracket })
\end{gathered}
$$

Base tax and tax rate values will change based on the federal taxable income for that production year. Table 3.3 shows the appropriate tax rates income brackets.

Table 3.3: U. S. federal income tax rate schedule for 2014

\begin{tabular}{|l|l|l|l|}
\hline \multicolumn{4}{|c|}{ U.S. Federal Income Tax Rate Schedule } \\
\hline Lower bracket $(\$)$ & Upper bracket (\$) & Base tax (\$) & Tax rate \\
\hline 0 & 50,000 & 0 & $15 \%$ \\
\hline 50,000 & 75,000 & 7,500 & $25 \%$ \\
\hline 75,000 & 100,000 & 13,750 & $34 \%$ \\
\hline 100,000 & 335,000 & 22,250 & $39 \%$ \\
\hline 335,000 & $10,000,000$ & 113,900 & $34 \%$ \\
\hline $10,000,000$ & $15,000,000$ & $3,400,000$ & $35 \%$ \\
\hline $15,000,000$ & $18,333,333$ & $5,150,000$ & $38 \%$ \\
\hline $18,333,333$ & & & $35 \%$ of income \\
\hline
\end{tabular}




\subsection{Lease Operating Expenses (LOE)}

Lease operating expenses (LOE) are different from the other production costs that have been mentioned in the drilling costs section. When enumerating these costs, LOE are additional costs that appear during the production phase. Some costs are already included in the D \& C costs (drilling and completion) section; however, other costs that are associated with an operating lease such as labor costs, site preparation and permitting fees including bonds and registration (initial application) costs, power, maintenance, and material costs are not included there. Depending on the drilling area and length of operating time, LOE will increase or decrease. Some studies regard site preparation fees, bond fees, and initial application fees separate from lease operating costs, however, many energy analysts consider them all together to calculate and to find accurate unit cost per barrel (Inkpen and Moffett 2011). In this research, these costs are considered together, and $\$ 10$ per barrel determined as the lease operating cost that was listed in SEC 10-k filings for the operators of North Dakota. LOE's are included in the cash flow statements. Most of the North Dakota companies are minimizing the LOE costs under their cost management programs.

The assumption of $\$ 10 \mathrm{LOE}$ cost is hold constant for the whole life span for any investment option. 


\subsection{Tax Benefits}

Prior to implementing the state and federal income taxes for North Dakota unconventional oil, several allowable tax deductions will occur depending on the state and federal regulations. These include the intangible drilling costs, tangible drilling costs, and depletion allowance.

\subsubsection{Tax Deductions for Intangible Drilling Cost}

Permitted intangible drilling deductions include labor costs, drilling rig rents, chemicals, drilling fluids, and fuel costs that occur during the drilling and completing processes of a well. These costs have no salvage value (PetroChase 2014).

Intangible drilling costs may cover 60 to 80 percent of the total drilling costs (North Dakota Oil Boom, 2014). This study assumes 70 percent of the total drilling costs are deductible as intangible drilling costs. Total drilling costs of a simulated Bakken well is assumed to be $\$ 8$ million and intangible costs are $\$ 5.6$ million.

\subsubsection{Tax Deductions for Tangible Drilling Cost}

Tangible drilling costs are related to drilling and completion costs encompassing the equipment have a salvage value in contrast to intangible drilling costs. Investors can either use modified accelerated cost recovery system (MACRS) or straight line depreciation system through seven years, whichever offers the best 
option for them (North Dakota Oil Boom 2014). For this method, 7-years MACRS depreciation was selected as the best option for an example property.

Table 3.4: 7 - years MACRS depreciation system (Internal Revenue Service 2013b)

\begin{tabular}{|l|l|}
\hline \multicolumn{2}{|c|}{ 7-years MACRS Depreciation Rates } \\
\hline Years & Rate (\%) \\
\hline 1 & 14.29 \\
\hline 2 & 24.49 \\
\hline 3 & 17.49 \\
\hline 4 & 12.49 \\
\hline 5 & 8.93 \\
\hline 6 & 8.93 \\
\hline 7 & 8.93 \\
\hline 8 & 4.46 \\
\hline
\end{tabular}

Since 70 percent is used as the intangible drilling costs, the remained 30 percent of the total drilling and completion costs is assumed to be the tangible drilling costs. Thus, $\$ 2.4$ million is the depreciable amount (basis) for the tangible drilling costs. 


\subsubsection{Depletion Allowance}

The depletion allowance is similar to depreciation, and is a form of cost recovery for capital investments (Internal Revenue Service 2013a). It can be calculated into two ways: cost depletion and percentage depletion. Investors who have an economic interest in an oil property can get a deduction for depletion (Internal Revenue Service 2013a). The simulated North Dakota wells in this research are assumed to be an asset (property) of an energy company instead of individual producers. To keep the calculation and assumption simple, a flat rate of 15 percent of the gross income is used based on the average daily production of oil for the percentage depletion (Internal Revenue Service 2013a). Thus, cost depletion is method is ignored.

\subsection{Scenarios}

Four different scenarios were are examined. Assessing the profitability and viability of these scenarios via cash flow statements is the main purpose of this study. These four scenarios are: first five years of production without re-stimulation; ten years of production without re-stimulation; twenty years of production without re-stimulation; and twenty years of production with two different well profiles, the first well producing oil for ten years, and the second well coming into the system after the tenth year and producing oil for ten more years. 
Different time frames and assumptions are selected to compare their overall profitability, feasibility, and the impact of production declines. NPV, IRR, and break-even analysis is used to assess these four scenarios.

The first three scenarios are similar, but their time frames compare the investment profitability over time. The EUR is calculated by using the decline curve graphs and decline curve equations. The first three scenarios show the production decline effect on the long run investments. All the basic assumptions remain the same for these scenarios, and leases are renewed every five years.

The fourth scenario used the same assumptions for the first ten years and then followed a different strategy than the first three simulations. The reason for using a different strategy is to assess the performance of two different ten year with two drilled wells. The first well is drilled and produced oil for the first ten years, and then the second well with the same features is drilled and produced oil for the next ten years. Therefore, it doubled the total drilling cost. Results will show how profitable this is.

\subsubsection{Re-fracturing}

Re-fracturing is an additional assumption and completely different from the other four scenarios. Re-fracturing operations do not always improve oil production. There are many steps that must be analyzed and carefully studied for re-fracturing. First, picking the target area is very important for perforations since re-fracturing the well might result in with opening new gaps. These gaps will lower the previous 
production via migration of the trapped oil from formation fractures. Another issue related to re-stimulation is the economic challenges of these operations. Restimulation will permit operators to boost oil production and this can be more economic than infill drilling if the reservoir characteristics are well known and the hydraulic fracture system is well placed (Strother et al. 2013). Each investment plan included in this system must be examined very carefully because investments could end up with uneconomic results.

Re-fracturing is logical because it evaluates the economics of re-fracturing efforts. In many American fields, operators started to think about the feasibility of re-fracturing because re-stimulation efforts may improve well performance for short periods. According to Schlumberger, work-overs and additional fracturing is able to increase oil production partly because of maintenance and remedial work (cleaning or replacing the pumps and fixing the frayed cement and casings) of the well (Schlumberger 2011). These work-overs will revitalize the well performance if refracturing is successful. On the other hand, each of these bring additional costs thereby increasing the total cost and will cause unprofitable investments.

In this analysis, re-fracturing option is not considered because the Bakken field unconventional oil operations are still in early years of production and refracturing is an active issue for the Bakken operators (based on cost \&environmental issues). Current results (mid-2014) show that companies mainly focus on drilling new wells to mitigate the decline effect. Also, gathering data for re-fracturing was 
unavailable because companies did not release any official report about re-fracturing until mid-2014.

\subsection{Calculations}

The analysis is made using cash flow statements, and the profitability decisions is measured using NPV, IRR, and break-even for each scenario. The first and the most important is the NPV of each cash flow statement since it is more reliable than IRR. To find the NPV or the present equivalent value of an investment, all future net cash flows are discounted to the present and summed together, using ten percent as the minimum acceptable return rate (hurdle rate). Positive NPVs for the scenarios are considered as acceptable and profitable.

The second comparison method is the IRR, which is also known as the economic rate of return on investment. IRR is defined as the annual average return that is earned over the investment life. Any IRR rate that is higher than the 10 percent Minimum Acceptable Rate of Return (MARR) is acceptable as a profitable investment.

The third method is break-even analysis. Break-even is the price of oil needed so that the NPV is equal to zero based on 10 percent MARR. An oil price higher than the break-even price is assumed to indicate an investible project. 


\section{Scenario Analysis and Results}

As discussed in Chapter 3, the main purpose of this study is to evaluate the economic profitability of the average (typical) Bakken unconventional oil well under current circumstances. This chapter covers an economic analysis of four different scenarios and considers the NPV, IRR, and break-even for each one. Cash flow statement analysis is the most important financial tool for assessing oil and gas investments and to pick the best alternative between the scenarios. Economic and environmental concerns associated with unconventional oil production were discussed in Chapter 2, and their impacts are examined in this chapter as well. Additionally, these scenarios tested the impact of the sharp production decline rates, and the EUR is calculated for each of the investment plans. Also, the assumed production periods and life span of a simulated well are other concerns and the results are analyzed to see whether five years production, ten years production, or 20 years production are more profitable in the analysis.

\subsection{Typical Bakken unconventional oil well (Simulated well)}

First of all, prior to calculating the cash flow statements and applying the financial decision analysis, the production decline rates and the EUR of each scenario were analyzed, calculated, and presented on the MS Excel spreadsheets. As anticipated, production performances of each scenario gave different results. Each of these scenarios began with the same IP rates and annual average decline rates. 
Hyperbolic decline curve and exponential decline curve analyses were implemented for the required periods. Table 4.1 presents the initial input values for the hyperbolic decline curve equation.

$$
q_{t}=\frac{q_{i}}{\left(1+b d_{i} * t\right)^{\frac{1}{b}}}
$$

Where;

$\mathrm{q}_{\mathrm{t}}=$ Production rate of the well at time $\mathrm{t}$, years

di: Initial nominal exponential decline rate $(\mathrm{t}=0)$, fraction / year

$\mathrm{q} i=$ Production rate of the well at time $0, \mathrm{t}=0$, barrel of oil per day (BOPD)

b= Hyperbolic exponent of decline, $b$-factor, characterizes reservoir's production decline

$\mathrm{t}=$ time $($ years $)$

Table 4.1: Input values for the hyperbolic decline curve (Simulated well)

\begin{tabular}{|l|l|}
\hline \multicolumn{2}{|c|}{ Hyperbolic decline curve equation input values } \\
\hline IP (initial production) rate & 406 bbls. / day \\
\hline Initial annual average decline rate $\left(\mathrm{d}_{\mathrm{i}}\right)$ / year & $68 \%$ \\
\hline b-variable (Hyperbolic exponent) & 1.1 \\
\hline
\end{tabular}


The hyperbolic exponent (b variable) must not be 0 or 1 to use in the hyperbolic decline equation. It is a constant value for specific periods and is estimated to be 1.1 for the initial year. This constant value is found by decline curve family graphs and calculations, and since it is a confidential data for the operator company, they did not want to share graph for this analysis. This b variable is assumed to be 1.1 for the beginning of the petroleum production estimates even though evaluators observed much higher numbers, approach to 2 in some cases during the flow regime (Ryder Scott Co. 2011). 1.1 constant value is considered based on the initial sharp declines. Indeed, the b variable is not dependent on the initial production. It can change during the production period, but this study assumes it will remain at 1.1 until the constant decline phase begins. Then $b$ variable will reach zero for the exponential curve equation. Table 4.1 shows that with the initial production rate of 406 bbls. per day, simulated well production also declines by a 68 percent annual average rate during the first year (12 months). If the b-value is greater, the decline occurs more sharply (the higher the value of $b$, the sharper the decline). These values remained fixed for the beginning of each scenario.

\subsubsection{Production Decline Curve for the First Scenario}

Oil or gas wells do not always have uniform production over their life spans. Conventional wells usually have a longer life span than unconventional fracked wells due to their drilling and reservoir structures. As this study concentrates on the unconventional oil wells of the North Dakota Bakken, extremely high decline rates 
after the peak period are more obvious than the extended peak periods of the conventional wells. In some North Dakota counties, it is even up to 85-90 percent during the initial year (North Dakota DMR). But, in this analysis, the typical simulated well performance declines at a 68 percent rate for the initial year, remains same for each scenario.

The first scenario covers the well performance over the first five years with average simulated well and market conditions. A sixty-eight percent initial decline rate tremendously affects oil production during the first five years as anticipated. Initially, daily production is assumed to be 406 bbls. / day and then decreases to 36 bbls. / day performance at the end of the fifth year. This is shown in figure 4.1 in terms of barrels per year.

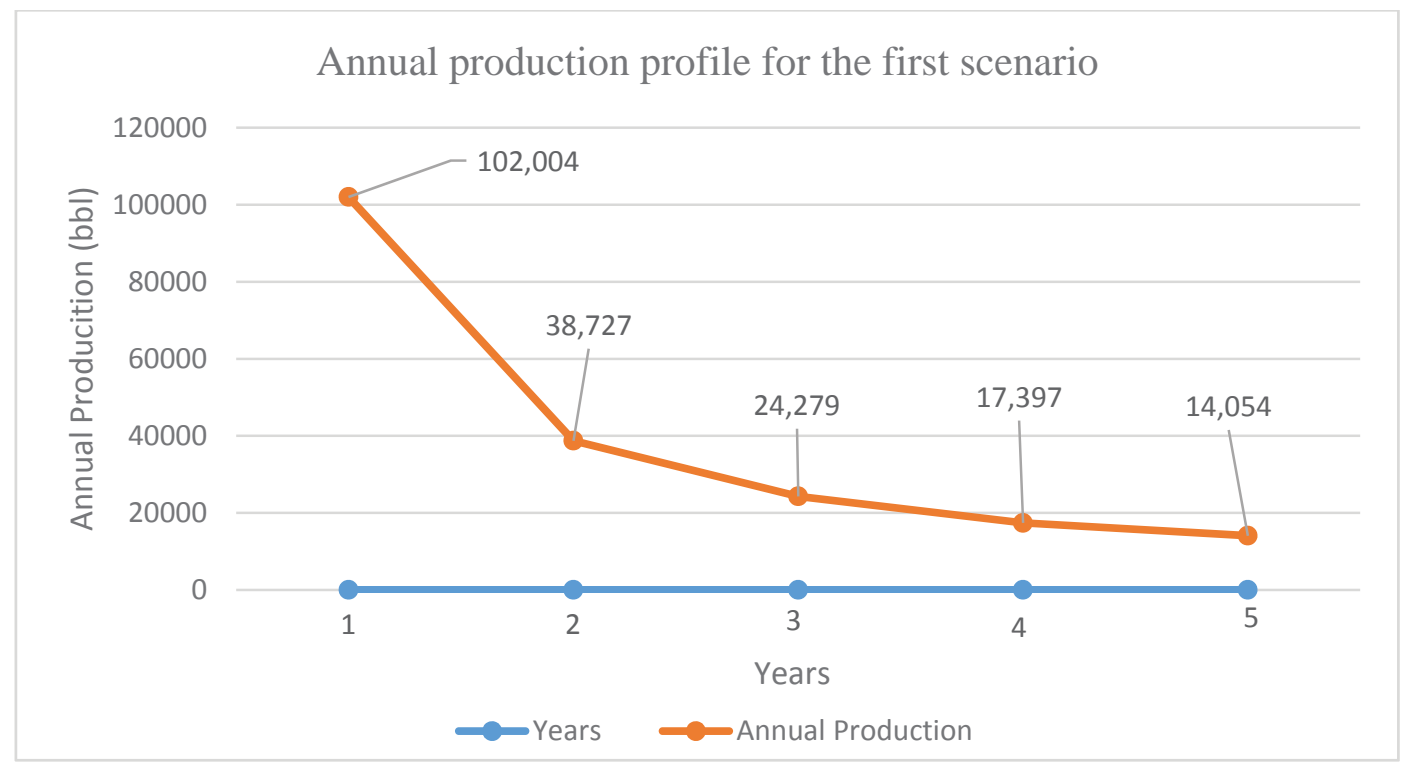

Figure 4.1: Production decline curve graph and annual oil production rates for the first scenario. 


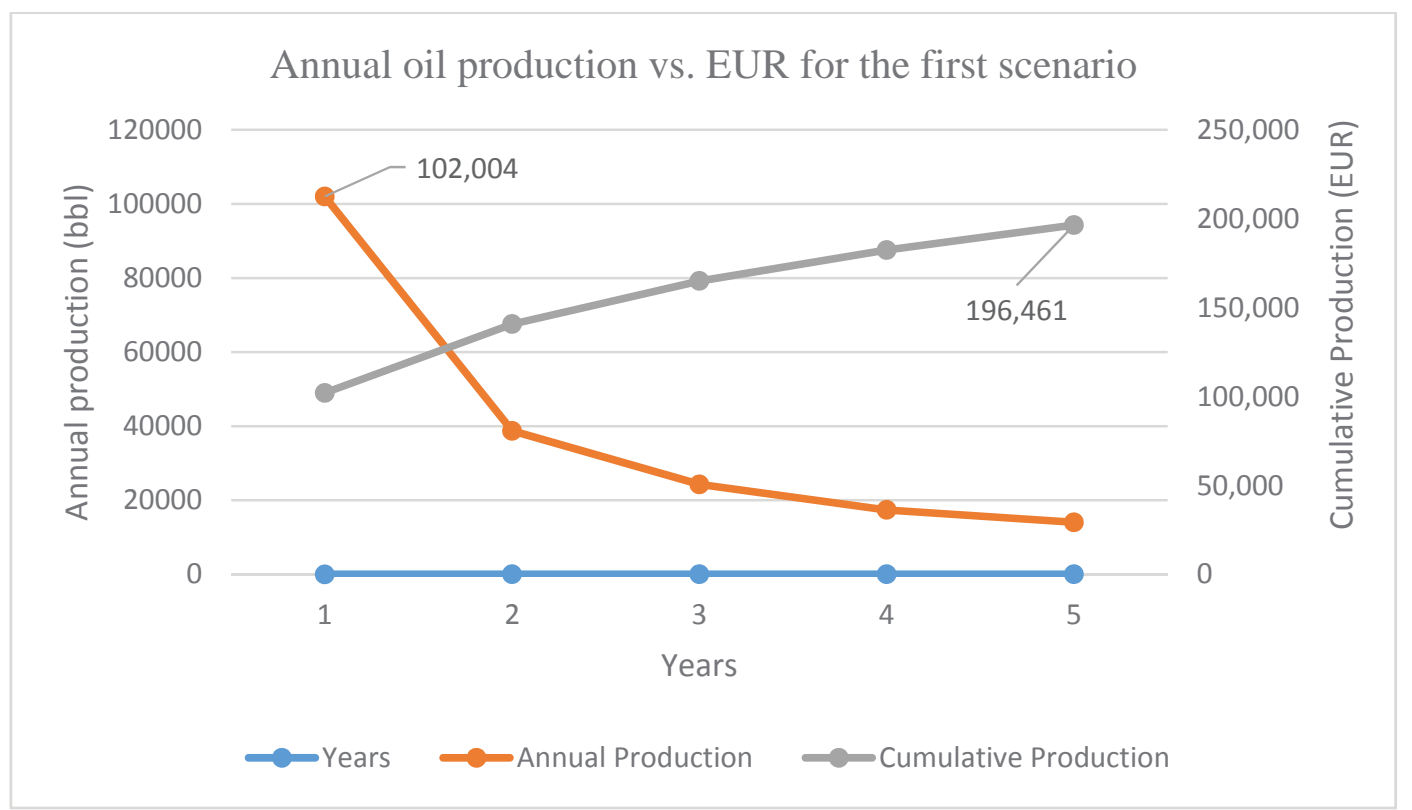

Figure 4.2.: Annual oil production vs. EUR for 5 years of the simulated Bakken well. EUR rises to 196,461 barrels after five years.

As seen from figure 4.1, during the five years period, production decline began rapidly, then the decline gradually decreased. The first year's total production was roughly 7.3 times of the fifth year's value. This decline is very crucial for the investors. The estimated ultimate recovery (EUR) rate of the first scenario was 196,461 bbls. for 5 years. The initial decline effect was much higher than in the following years, and the last 4 years' cumulative production could not reach the first year's total extraction. The initial year's production was accounted for 52 percent of the first five years cumulative amount. 


\subsubsection{Production Decline Curve for the Second Scenario}

The second scenario consists of a ten year period of production without restimulation or other additional maintenance. The second production decline curve is presented in Figure 4.3, and it includes the first scenario plus the years of production 6 through 10. Annual production decreased to 9,994 bbls. at the end of tenth year. Thus, the initial year's oil production is more than nine times the tenth year's production.

The EUR of the first scenario was 196,461 bbls. and increased to 252,252 bbls. at the end of 10 years in this second scenario. The decline rate became constant at a five percent rate after the seventh year. For that reason, the hyperbolic curve shifted to an exponential decline curve until the end of the scenario. The impact of the production decline slowed down, and the average daily production was approximately 26.7 bbls. / day at the end of the tenth year. 


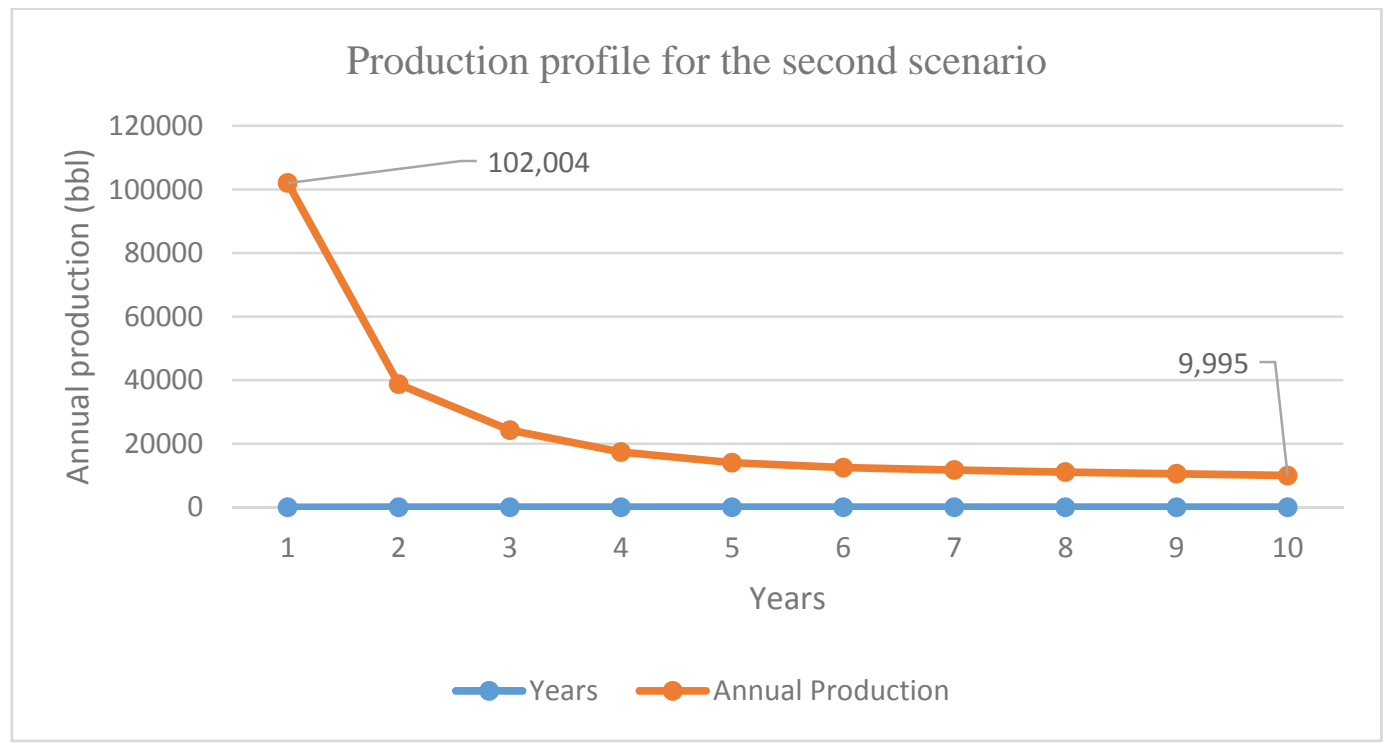

Figure 4.3: Production decline curve for the second scenario

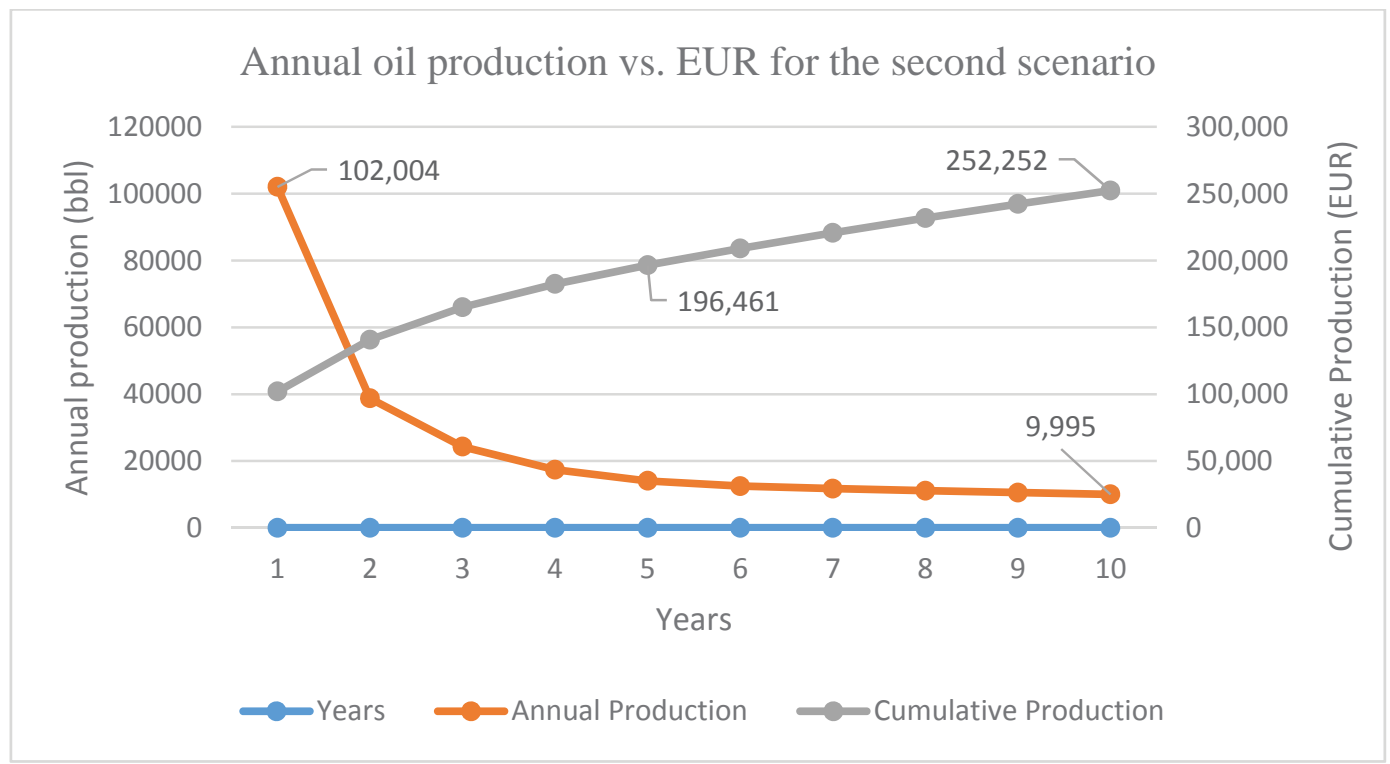

Figure 4.4: Annual Production and EUR graph for the second scenario. EUR increased from 196,461 bbls. to 252,252 bbls. in five years, including the years 6 through 10. Production decline rate became constant in this period at a five percent rate. 


\subsubsection{Production Decline Curve for the Third Scenario}

The previous scenarios covered five and ten year production periods without re-stimulation and work overs. The third scenario is a continuation of the second case, with an additional ten years. For the first two scenarios, the approximate EUR was around 196,461 and 252,252 bbls. An additional ten year adds roughly 76,000 bbls. of oil, and the EUR of the third scenario is enhanced to 328,453 bbls. at the end of twenty years. When compared to the first ten years, the additional ten year production was low; it only accounted for 30 percent of the first ten years.

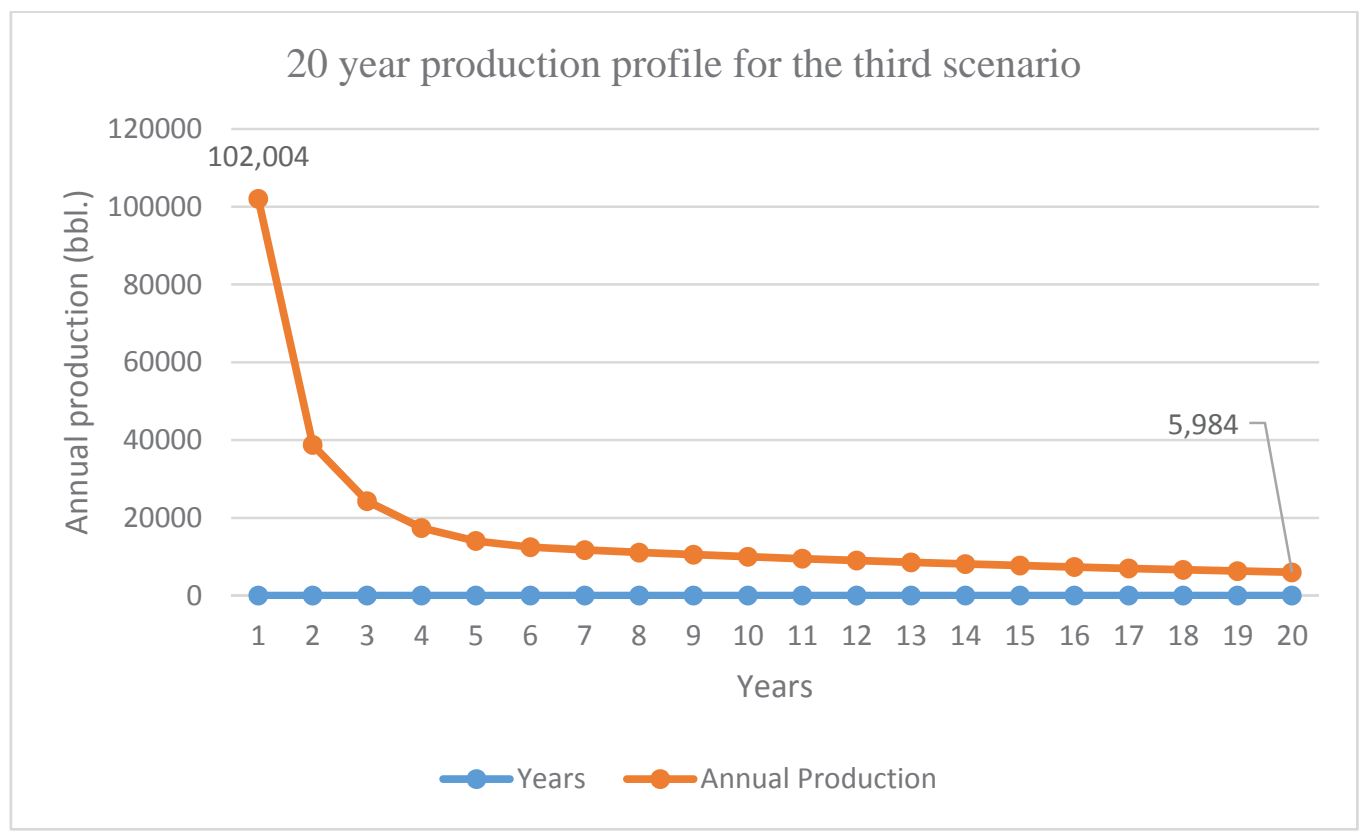

Figure 4.5: 20 year production decline curve for the third scenario 


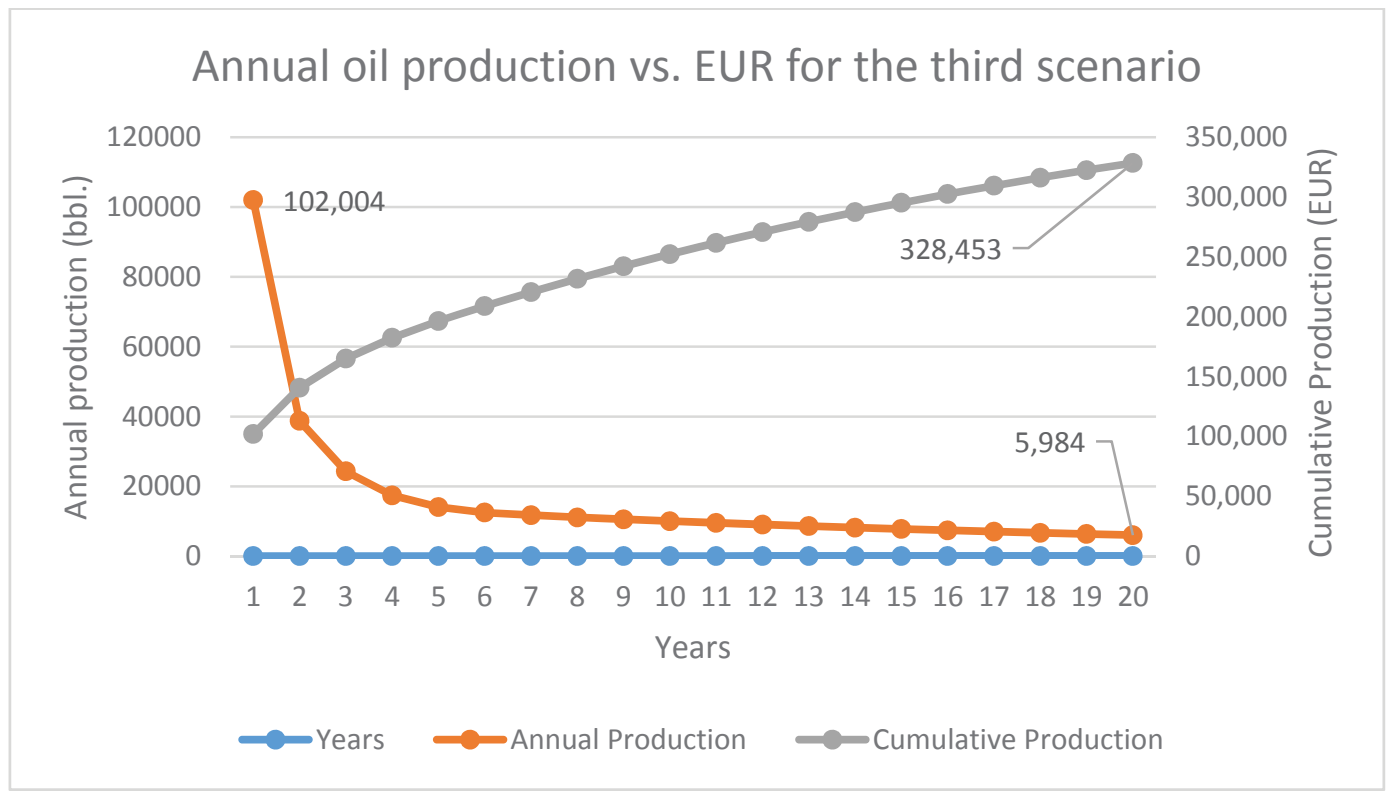

Figure 4.6: Annual oil production vs. cumulative EUR graph for the third scenario. It improved to $328,453 \mathrm{bbls}$. at the end of twenty years without re-stimulation and maintenance.

After reaching the constant decline rate ( 5 percent), the production decline curve becomes flatter. The sharp decline effect ended after the initial production years. After the first few years, production declines gradually and the economic impact of oil declined in the same way. In 20 years, the economic limit could occur since the production rate has fallen from 406 bbls. / day to 16 bbls. / day as opposed to costs which are increasing. It is crucial to observe the economic limit and make a final decision for the next operations. As mentioned before, the operators will have two options for the future investments: either shut down the current well and drill a new one after the tenth year, or consider re-stimulation / re-fracturing efforts. The re-fracturing works do not always give feasible results since the depletion and the migration of oil is very different from gas. Pore fractures will lower and leak the 
trapped oil. New packing tools and hydro-fracking stages will increase the production if the target packing zones install successfully. On the other hand, if the operations extend beyond the target zones and all the fractured zones are restimulated again, it will be costly without yielding expected oil returns.

Therefore, the third scenario leads to the fourth scenario with the idea of drilling a replacement well with the same features at year ten, and each well would produce for ten years.

\subsubsection{Production Decline Curve for the Fourth Scenario}

This scenario is different from the first three versions. A twenty year life span is divided into two different well production sections. The initial well drilled in year 0 is produced oil until the end of year 10. The second well is drilled at the end of year 10 and produces oil in years 11 through 20. Both of these wells are assumed to have the same geological and reservoir features. In other words, the second scenario is duplicated here. If the second scenario was profitable, the duplication of it should give better results for a 20 years life span than the third scenario because the production rates between the end of the tenth year and the twentieth year were extremely low in the third scenario.

On the other hand, if the second scenario did not have positive NPV, duplicating the negative results would only make the deficit worse. The reason for the comparing these two scenarios is to evaluate the best investment for long run plan. 


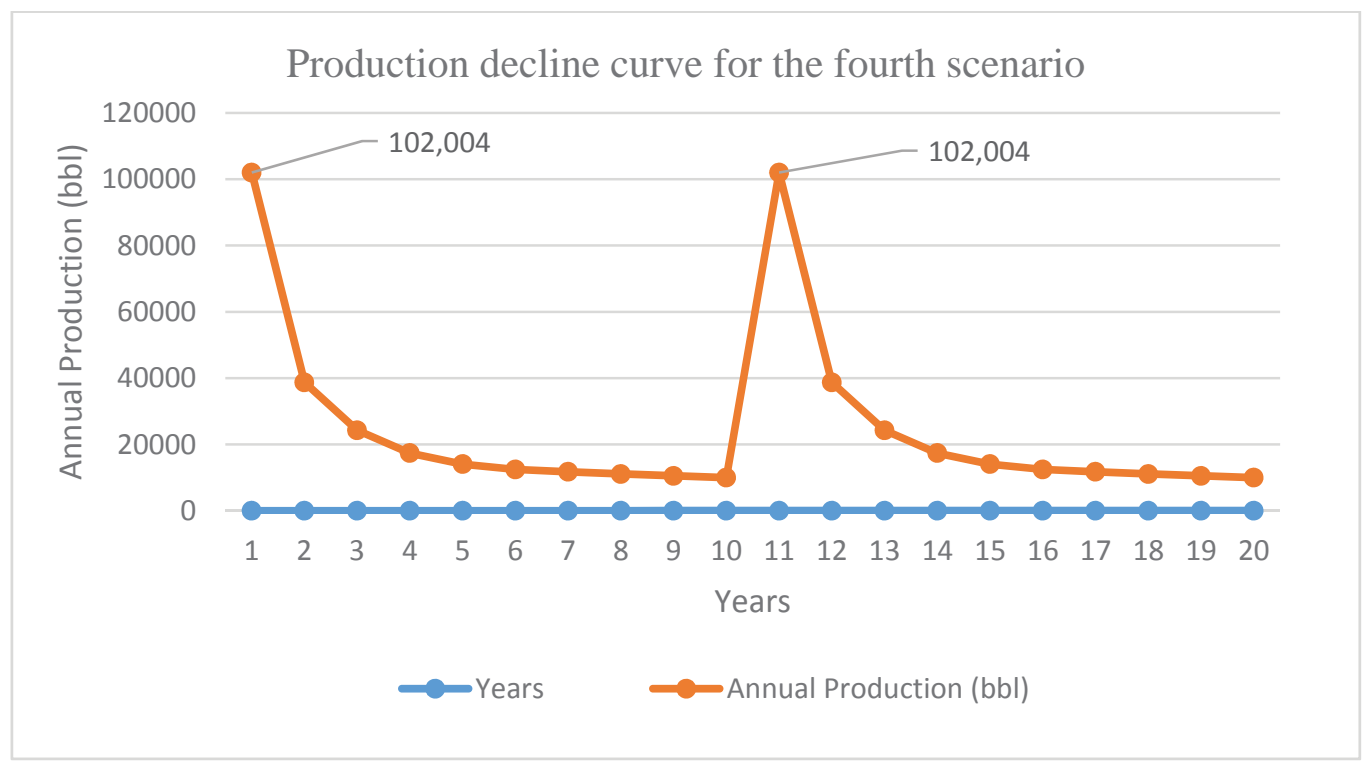

Figure 4.7: Production decline curve for the fourth scenario (Duplication of the second scenario over 20 years)

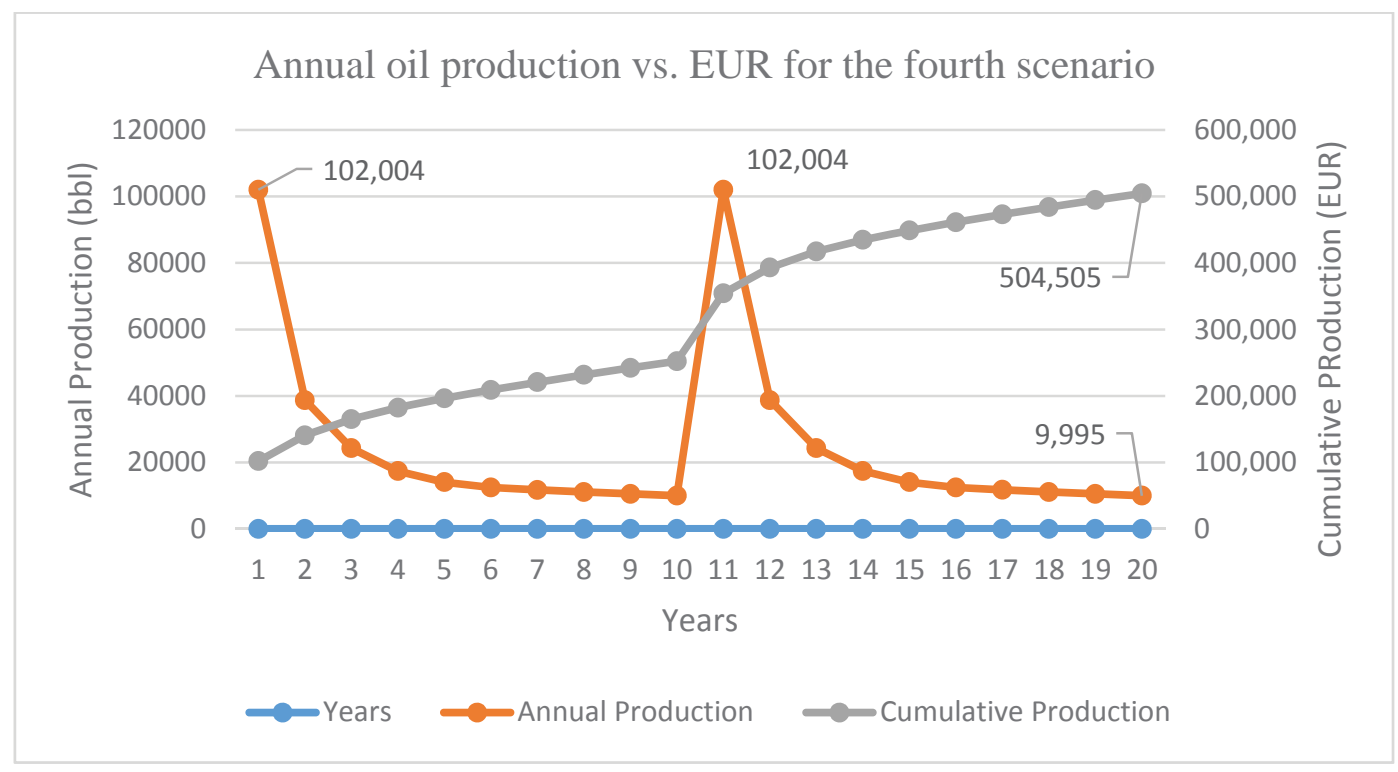

Figure 4.8: Production profile vs. EUR for the fourth scenario. Expected ultimate recovery increased to 504,505 bbls. 
The expected ultimate recovery is highest in the fourth scenario. The highest EUR of the previous scenarios was 328,453 bbls. and it improved to 504,505 bbls. at the end of twenty years. In this scenario the cash flow statement analysis will show which scenario is more profitable, but EUR results show that the maximum oil extraction exists in the fourth scenario. The main concern of the fourth scenario was the cost / benefit side because not only is the production doubled but the total drilling cost is also doubled in this scenario. Therefore, a positive NPV could improve the profitable investment and rate of return, but a negative NPV could increase the deficit and lower the investible life span of the project.

Without the analysis in cash flow statements, interpreting the investments based on the EUR values will give incorrect results. The highest EUR rate observed in the fourth scenario, and the lowest EUR existed in the first one due to the shortest production time frame. Another incorrect approach would be to link production rates with profitability. Production rates decline significantly after the initial years. Investors may want to stop operations due to high decline rates, but this is also incorrect.

The analysis using cash flow statements are needed to find the best and the worst investments. 


\subsection{Cash Flow Statements for Scenarios}

\subsubsection{First Scenario (5 years production)}

In the previous chapter, all assumptions related to the cash flow statements were explained and defined. These input variables are based on the current market conditions that can be observable in the North Dakota Bakken Field. Some of these will change or vary due to changeable conditions, regional differences, and well characteristics. The initial cost variables are shown in Table 4.2.

Table 4.2: Simulated Bakken unconventional oil well initial input values

\begin{tabular}{|l|l|}
\hline \multicolumn{2}{|c|}{ Initial variables for the simulated Bakken well (as of mid-2014) } \\
\hline D \& C costs (Total Drilling Cost) & $\$ 8,000,000$ \\
\hline Intangible Drilling Cost & $\$ 5,600,000$ \\
\hline Tangible Drilling Cost & $\$ 2,400,000$ \\
\hline Clearbrook Oil Price (per barrel) & $\$ 90.78$ \\
\hline Royalty rate & $12.5 \%$ \\
\hline Lease operating expenses (per barrel) & $\$ 10$ \\
\hline Signing bonus fees (per acre) & $\$ 3,000$ \\
\hline Inflation (oil price increase per year) & $2.8 \%$ \\
\hline Initial annual average decline rate & $68 \%$ \\
\hline State taxes (extraction and gross production) & $11.5 \%$ \\
\hline Depletion Allowance & $15 \%$ \\
\hline Initial production rate (IP) & $406 \mathrm{bbls.} \mathrm{/} \mathrm{day}$ \\
\hline Minimum Acceptable Rate of Return (MARR) & $10 \%$ \\
\hline
\end{tabular}




\begin{tabular}{|c|c|c|c|c|c|}
\hline Year & $\mathbf{0}$ & 1 & 2 & 3 & 4 \\
\hline \multicolumn{6}{|l|}{ Revenue } \\
\hline Production & 0 & 102,004 & 38,727 & 24,279 & 17,397 \\
\hline $\begin{array}{r}\text { Price of oil } \\
(\$ / \mathrm{bbl} .)\end{array}$ & 0 & 90.8 & 93.3 & 95.9 & 98.6 \\
\hline Gross Revenue & 0 & $9,259,934$ & $3,614,074$ & $2,329,245$ & $1,715,690$ \\
\hline Royalty (12.5\%) & 0 & $1,157,492$ & 451,759 & 291,156 & 214,461 \\
\hline Net Revenue & 0 & $8,102,442$ & $3,162,314$ & $2,038,090$ & $1,501,229$ \\
\hline \multicolumn{6}{|l|}{ Costs } \\
\hline LOE (\$ per bbl.) & 0 & 10 & 10 & 10 & 10 \\
\hline $\begin{array}{r}\text { LOE cost }(\$ x \\
\text { bbl.) }\end{array}$ & 0 & $-1,020,041$ & $-387,270$ & $-242,794$ & $-173,968$ \\
\hline $\begin{array}{c}\text { Intangible } \\
\text { Drilling Costs }\end{array}$ & $-5,600,000$ & 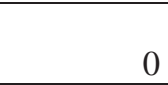 & 0 & 0 & 0 \\
\hline $\begin{array}{r}\text { Lease Cost ( } 5 \\
\text { year) }\end{array}$ & $-1,920,000$ & 0 & 0 & 0 & 0 \\
\hline \multicolumn{6}{|l|}{ Non - cash costs } \\
\hline $\begin{array}{r}\text { Tangible } \\
\text { Drilling Costs } \\
\text { Depreciation } \\
\end{array}$ & 0 & $-342,960$ & $-587,760$ & $-419,760$ & $-299,760$ \\
\hline $\begin{array}{r}\text { Cost Based } \\
\text { Depletion } \\
(15 \%) \\
\end{array}$ & 0 & $-1,388,990$ & $-542,111$ & $-349,387$ & $-257,353$ \\
\hline Total Costs & $-7,520,000$ & $-2,751,991$ & $-1,517,141$ & $-1,011,941$ & $-731,081$ \\
\hline $\begin{array}{l}\text { Taxable } \\
\text { Income }\end{array}$ & $-7,520,000$ & $5,350,451$ & $1,645,174$ & $1,026,148$ & 770,147 \\
\hline $\begin{array}{r}\text { State Tax } \\
(5 \%+6.5 \%) \\
\end{array}$ & 864,800 & $-615,302$ & $-189,195$ & $-118,007$ & $-88,567$ \\
\hline $\begin{array}{r}\text { Federal Taxable } \\
\text { Income }\end{array}$ & $-6,655,200$ & $4,735,149$ & $1,455,979$ & 908,141 & 681,580 \\
\hline Federal Tax & $2,262,768$ & $-1,609,951$ & $-495,033$ & $-308,768$ & $-231,737$ \\
\hline $\begin{array}{l}\text { Income After } \\
\text { Tax }\end{array}$ & $-4,392,432$ & $3,125,198$ & 960,946 & 599,373 & 449,843 \\
\hline \multicolumn{6}{|l|}{ Non-cash charges } \\
\hline Depreciation & 0 & 342,960 & 587,760 & 419,760 & 299,760 \\
\hline Cost Depletion & 0 & $1,388,990$ & 542,111 & 349,387 & 257,353 \\
\hline \multicolumn{6}{|c|}{ Capital Expenditures } \\
\hline $\begin{array}{r}\text { Tangible } \\
\text { Drilling Costs }\end{array}$ & $-2,400,000$ & 0 & 0 & 0 & 0 \\
\hline Net Cash Flow & $-6,792,432$ & $4,857,148$ & $2,090,817$ & $1,368,520$ & $1,006,956$ \\
\hline $\begin{array}{l}\text { Present Value } \\
@(10 \%)\end{array}$ & $-6,792,432$ & $4,415,589$ & $1,727,948$ & $1,028,189$ & 687,765 \\
\hline $\mathbf{N P V}=$ & $\$ 1,579,000$ & & & & \\
\hline
\end{tabular}

Figure 4.9a: Cash flow statements for the first scenario years 0 through 4. (NPV \$ amounts rounded to the nearest $\$ 1000$ ) The initial daily production rate was 40 bbls. and the annual nominal decline rate was 68 percent. 


\begin{tabular}{|c|c|}
\hline Year & 5 \\
\hline \multicolumn{2}{|l|}{ Revenue } \\
\hline Production & 14,054 \\
\hline Price of oil $(\$ / b b l)$. & 101.4 \\
\hline Gross Revenue & $1,424,796$ \\
\hline Royalty Fee $(12.5 \%)$ & 178,099 \\
\hline Net Revenue & $1,246,696$ \\
\hline \multicolumn{2}{|l|}{ Costs } \\
\hline LOE (\$ per bbl.) & 10 \\
\hline LOE cost (\$ $x$ bbl. $)$ & $-140,537$ \\
\hline Intangible Drilling Costs & 0 \\
\hline Lease Cost (5 year) & 0 \\
\hline \multicolumn{2}{|l|}{ Non - cash costs } \\
\hline Tangible Drilling Costs Depreciation & $-214,320$ \\
\hline Cost Based Depletion (15\%) & $-213,719$ \\
\hline Total Costs & $-568,576$ \\
\hline Taxable Income & 678,120 \\
\hline State Tax $(5 \%+6.5 \%)$ & $-77,984$ \\
\hline Federal Taxable Income & 600,136 \\
\hline Federal Tax & $-204,046$ \\
\hline Income After Tax & 396,090 \\
\hline \multicolumn{2}{|l|}{ Non-cash charges } \\
\hline Depreciation & 214,320 \\
\hline Cost Depletion & 213,719 \\
\hline \multicolumn{2}{|l|}{ Capital Expenditures } \\
\hline Tangible Drilling Costs & 0 \\
\hline Net Cash Flow & 824,129 \\
\hline Present Value @ (10\%) & 511,719 \\
\hline
\end{tabular}

Figure 4.9b: Cash flow statement for the first scenario, encompassing years 0

through 5. Figure 4.9a covers the statement for years 0 through 4.

NPV and IRR are the two financial parameters used to assess the investment profitability (attractiveness) based on the given circumstances. Table 4.3 presents these results for the first scenario that covers years 0 through 5 . 
Table 4.3: Profitably and EUR results for the first scenario

\begin{tabular}{|l|l|}
\hline \multicolumn{2}{|c|}{ Results for years 0 through 5 } \\
\hline NPV @ MARR = 10 \% & $\$ 1,579,000$ \\
\hline IRR & $23.1 \%$ \\
\hline EUR & 196,461 bbls. \\
\hline
\end{tabular}

Any NPV result greater than zero means the investment is acceptable. The NPV for the first scenario is $\$ 1,579,000$ based on assumptions at current market conditions. Thus, the first scenario is profitable based on the five year time frame. Total costs of Bakken (D \&C plus other fees) are relatively higher than some other unconventional areas like the Marcellus Shale or the Barnett Shale. But the initial flow rate offsets these costs and gives positive results for the 5 year investment plan.

\subsubsection{Second Scenario (10 years production)}

The second scenario includes ten year production profile. The initial input values remain same as the first scenario and additional 5 year production profile increases the cumulative production (EUR) from 196,461 bbls. to 252,252 bbls at the end of ten years. Cash flow statement analysis for the second scenario is shown in Figure 4.10a, 4.10b, and 4.10c. 


\begin{tabular}{|c|c|c|c|c|c|}
\hline Year & $\mathbf{0}$ & 1 & 2 & 3 & 4 \\
\hline \multicolumn{6}{|l|}{ Revenue } \\
\hline Production & 0 & 102,004 & 38,727 & 24,279 & 17,397 \\
\hline $\begin{array}{r}\text { Price of oil } \\
(\$ / \mathrm{bbl} .)\end{array}$ & 0 & 90.8 & 93.3 & 95.9 & 98.6 \\
\hline Gross Revenue & 0 & $9,259,934$ & $3,614,074$ & $2,329,245$ & $1,715,690$ \\
\hline $\begin{array}{l}\text { Royalty } \\
(12.5 \%)\end{array}$ & 0 & $1,157,492$ & 451,759 & 291,156 & 214,461 \\
\hline Net Revenue & 0 & $8,102,442$ & $3,162,314$ & $2,038,090$ & $1,501,229$ \\
\hline \multicolumn{6}{|l|}{ Costs } \\
\hline $\begin{array}{r}\text { LOE (\$ per } \\
\text { bbl.) }\end{array}$ & 0 & 10 & 10 & 10 & 10 \\
\hline $\begin{array}{r}\text { LOE cost }(\$ x \\
\text { bbl.) }\end{array}$ & 0 & $-1,020,041$ & $-387,270$ & $-242,794$ & $-173,968$ \\
\hline $\begin{array}{r}\text { Intangible } \\
\text { Drilling Costs }\end{array}$ & $-5,600,000$ & 0 & 0 & 0 & 0 \\
\hline $\begin{array}{r}\text { Lease Cost ( } 5 \\
\text { year) }\end{array}$ & $-1,920,000$ & 0 & 0 & 0 & 0 \\
\hline \multicolumn{6}{|l|}{ Non - cash costs } \\
\hline $\begin{array}{r}\text { Tangible } \\
\text { Drilling Costs } \\
\text { Depr. }\end{array}$ & 0 & $-342,960$ & $-587,760$ & $-419,760$ & $-299,760$ \\
\hline $\begin{array}{r}\text { Cost Based } \\
\text { Depletion } \\
(15 \%) \\
\end{array}$ & 0 & $-1,388,990$ & $-542,111$ & $-349,387$ & $-257,353$ \\
\hline Total Costs & $-7,520,000$ & $-2,751,991$ & $-1,517,141$ & $-1,011,941$ & $-731,081$ \\
\hline Taxable Inc. & $-7,520,000$ & $5,350,451$ & $1,645,174$ & $1,026,148$ & 770,147 \\
\hline $\begin{array}{r}\text { State Tax } \\
(5 \%+6.5 \%) \\
\end{array}$ & 864,800 & $-615,302$ & $-189,195$ & $-118,007$ & $-88,567$ \\
\hline $\begin{array}{r}\text { Federal Taxable } \\
\text { Income }\end{array}$ & $-6,655,200$ & $4,735,149$ & $1,455,979$ & 908,141 & 681,580 \\
\hline Federal Tax & $2,262,768$ & $-1,609,951$ & $-495,033$ & $-308,768$ & $-231,737$ \\
\hline Income A. Tax & $-4,392,432$ & $3,125,198$ & 960,946 & 599,373 & 449,843 \\
\hline \multicolumn{6}{|l|}{ Non-cash charges } \\
\hline Depreciation & 0 & 342,960 & 587,760 & 419,760 & 299,760 \\
\hline Cost Depletion & 0 & $1,388,990$ & 542,111 & 349,387 & 257,353 \\
\hline \multicolumn{6}{|c|}{ Capital Expenditures } \\
\hline $\begin{array}{r}\text { Tangible D. } \\
\text { Cost }\end{array}$ & $-2,400,000$ & 0 & 0 & 0 & 0 \\
\hline Net Cash Flow & $-6,792,432$ & $4,857,148$ & $2,090,817$ & $1,368,520$ & $1,006,956$ \\
\hline PV @ (10\%) & $-6,792,432$ & $4,415,589$ & $1,727,948$ & $1,028,189$ & 687,765 \\
\hline
\end{tabular}

Figure 4.10a: Cash flow statements for the second scenario between years 0 and 4 . The initial production is 406 bbls. / day and a 68 percent annual decline rate used. 


\begin{tabular}{|c|c|c|c|c|c|}
\hline Year & 5 & 6 & 7 & 8 & 9 \\
\hline \multicolumn{6}{|l|}{ Revenue } \\
\hline Production & 14,054 & 12,475 & 11,726 & 11,075 & 10,521 \\
\hline $\begin{array}{r}\text { Price of oil } \\
(\$ / b b l .)\end{array}$ & 101.4 & 104.2 & 107.1 & 110.1 & 113.2 \\
\hline $\begin{array}{r}\text { Gross } \\
\text { Revenue }\end{array}$ & $1,424,796$ & $1,300,133$ & $1,256,345$ & $1,219,753$ & $1,191,211$ \\
\hline $\begin{array}{l}\text { Royalty } \\
(12.5 \%) \\
\end{array}$ & 178,099 & 162,517 & 157,043 & 152,469 & 148,901 \\
\hline $\begin{array}{l}\text { Net } \\
\text { Revenue }\end{array}$ & $1,246,696$ & $1,137,617$ & $1,099,302$ & $1,067,284$ & $1,042,309$ \\
\hline \multicolumn{6}{|l|}{ Costs } \\
\hline $\begin{array}{r}\text { LOE (\$ per } \\
\text { bbl.) }\end{array}$ & 10 & 10 & 10 & 10 & 10 \\
\hline $\begin{array}{r}\text { LOE cost }(\$ \\
\times \text { bbl.) }\end{array}$ & $-140,537$ & $-124,748$ & $-117,263$ & $-110,746$ & $-105,209$ \\
\hline $\begin{array}{r}\text { Intangible } \\
\text { Drilling } \\
\text { Costs }\end{array}$ & 0 & 0 & 0 & 0 & 0 \\
\hline $\begin{array}{r}\text { Lease Cost } \\
(5 \text { year })\end{array}$ & $-1,920,000$ & 0 & 0 & & 0 \\
\hline \multicolumn{6}{|c|}{ Non - cash costs } \\
\hline $\begin{array}{c}\text { Tangible } \\
\text { Drill. Depr. }\end{array}$ & $-214,320$ & $-214,320$ & $-214,320$ & $-107,160$ & 0 \\
\hline $\begin{array}{r}\text { Cost Based } \\
\text { Depletion }\end{array}$ & $-213,719$ & $-195,020$ & $-188,452$ & $-182,963$ & $-178,682$ \\
\hline Total Costs & $-2,488,576$ & $-534,088$ & $-520,034$ & $-400,869$ & $-283,891$ \\
\hline $\begin{array}{l}\text { Taxable } \\
\text { Income }\end{array}$ & $-1,241,880$ & 603,529 & 579,267 & 666,414 & 758,419 \\
\hline $\begin{array}{r}\text { State Tax } \\
(5 \%+6.5 \%)\end{array}$ & 142,816 & $-69,406$ & $-66,616$ & $-76,638$ & $-87,218$ \\
\hline $\begin{array}{c}\text { Federal } \\
\text { Taxable } \\
\text { Income }\end{array}$ & $-1,099,064$ & 534,123 & 512,652 & 589,777 & 671,200 \\
\hline Federal Tax & 373,682 & $-181,602$ & $-174,302$ & $-200,524$ & $-228,208$ \\
\hline $\begin{array}{l}\text { Income } \\
\text { After Tax }\end{array}$ & $-725,382$ & 352,521 & 338,350 & 389,253 & 442,992 \\
\hline \multicolumn{6}{|c|}{ Non-cash charges } \\
\hline Depreciation & 214,320 & 214,320 & 214,320 & 107,160 & 0 \\
\hline $\begin{array}{r}\text { Cost } \\
\text { Depletion } \\
\end{array}$ & 213,719 & 195,020 & 188,452 & 182,963 & 178,682 \\
\hline \multicolumn{6}{|c|}{ Capital Expenditures } \\
\hline Tangible D. & 0 & 0 & 0 & 0 & 0 \\
\hline $\begin{array}{l}\text { Net Cash } \\
\text { Flow }\end{array}$ & $-297,343$ & 761,861 & 741,122 & 679,376 & 621,674 \\
\hline PV @10 \% & $-184,626$ & 430,051 & 380,313 & 316,934 & 263,650 \\
\hline
\end{tabular}

Figure 4.10b: Years 5 through 9 for the second scenario 


\begin{tabular}{|c|c|}
\hline Year & 10 \\
\hline \multicolumn{2}{|l|}{ Revenue } \\
\hline Production & 9,995 \\
\hline Price of oil ( $\$ / b b l)$. & 116.4 \\
\hline Gross Revenue & $1,163,336$ \\
\hline Royalty Fee $(12.5 \%)$ & 145,417 \\
\hline Net Revenue & $1,017,919$ \\
\hline \multicolumn{2}{|l|}{ Costs } \\
\hline LOE (\$ per bbl.) & 10 \\
\hline LOE cost ( $\$ \mathrm{x}$ bbl. $)$ & $-99,949$ \\
\hline Intangible Drilling Costs & 0 \\
\hline Lease Cost (5 year) & 0 \\
\hline \multicolumn{2}{|l|}{ Non - cash costs } \\
\hline Tangible Drilling Costs Depreciation & 0 \\
\hline Cost Based Depletion (15\%) & $-174,500$ \\
\hline Total Costs & $-274,449$ \\
\hline Taxable Income & 743,470 \\
\hline State Tax $(5 \%+6.5 \%)$ & $-85,499$ \\
\hline Federal Taxable Income & 657,971 \\
\hline Federal Tax & $-223,710$ \\
\hline Income After Tax & 434,261 \\
\hline \multicolumn{2}{|l|}{ Non-cash charges } \\
\hline Depreciation & 0 \\
\hline Cost Depletion & 174,500 \\
\hline \multicolumn{2}{|l|}{ Capital Expenditures } \\
\hline Tangible Drilling Costs & 0 \\
\hline Net Cash Flow & 608,761 \\
\hline Present Value @ (10\%) & 234,704 \\
\hline
\end{tabular}

Figure 4.10c: Cash flow statement for the second scenario, year 10.

The cash flow statement for the second scenario is given above. The 10 year time frame gave a positive NPV result that is acceptable for the investment. When compared to the first scenario, the NPV is greater, which means the second scenario is more profitable than the first one. Moreover, the IRR of the second scenario is equal to $25.6 \%$, which is much higher than the 10 percent hurdle rate. If a comparison is done between the first two scenarios; the second one gives higher profitability. Table 4.4 exhibits the results of the financial parameters for this scenario. 
Table 4.4: Profitability and EUR results for the second scenario.

\begin{tabular}{|l|l|}
\hline \multicolumn{2}{|c|}{ Results for years 0 through 10 } \\
\hline NPV @ MARR=10\% & $\$ 2,508,000$ \\
\hline IRR & $25.6 \%$ \\
\hline EUR & 252,252 bbls. \\
\hline
\end{tabular}

The financial parameters and the EUR demonstrate that both scenarios are acceptable but if only one of them could be chosen, then the second one must be selected since the NPV is roughly $\$ 1$ million higher than the first scenario. Even though the initial investment is large, the first scenario reached the positive NPV results at the end of the third year, thus any more years with positive net cash flows improves the profitability. The second scenario is more profitable than the first one even with the declining flow rates and the re-leasing expense in year 5. The third scenario will show whether producing ten more years with the same well is better or not.

\subsubsection{Third Scenario ( 20 years production)}

The third scenario is a continuation of the second scenario and adds 10 more year production profile into the system. Cash flow statement analysis for the third scenario is shown in Figure 4.11a, 4.11b, 4.11c, 4.11d, and 4.11e. 


\begin{tabular}{|c|c|c|c|c|c|}
\hline Year & $\mathbf{0}$ & 1 & 2 & 3 & 4 \\
\hline \multicolumn{6}{|l|}{ Revenue } \\
\hline Production & 0 & 102,004 & 38,727 & 24,279 & 17,397 \\
\hline $\begin{array}{r}\text { Price of oil } \\
\text { (\$/bbl.) }\end{array}$ & 90.8 & 93.3 & 95.9 & 98.6 & 90.8 \\
\hline Gross Revenue & 0 & $9,259,934$ & $3,614,074$ & $2,329,245$ & $1,715,690$ \\
\hline Royalty $(12.5 \%)$ & 0 & $1,157,492$ & 451,759 & 291,156 & 214,461 \\
\hline Net Revenue & 0 & $8,102,442$ & $3,162,314$ & $2,038,090$ & $1,501,229$ \\
\hline \multicolumn{6}{|l|}{ Costs } \\
\hline LOE (\$ per bbl.) & 0 & 10 & 10 & 10 & 10 \\
\hline $\begin{array}{r}\text { LOE cost }(\$ x \\
\text { bbl.) }\end{array}$ & 0 & $-1,020,041$ & $-387,270$ & $-242,794$ & $-173,968$ \\
\hline $\begin{array}{c}\text { Intangible } \\
\text { Drilling Costs }\end{array}$ & $-5,600,000$ & 0 & 0 & 0 & 0 \\
\hline $\begin{array}{r}\text { Lease Cost ( } 5 \\
\text { year) }\end{array}$ & $-1,920,000$ & 0 & 0 & 0 & 0 \\
\hline \multicolumn{6}{|l|}{ Non - cash costs } \\
\hline $\begin{array}{r}\text { Tangible } \\
\text { Drilling Depr. }\end{array}$ & 0 & $-342,960$ & $-587,760$ & $-419,760$ & $-299,760$ \\
\hline $\begin{array}{r}\text { Cost Based } \\
\text { Depletion }(15 \%) \\
\end{array}$ & 0 & $-1,388,990$ & $-542,111$ & $-349,387$ & $-257,353$ \\
\hline Total Costs & $-7,520,000$ & $-2,751,991$ & $-1,517,141$ & 1,011,941 & $-731,081$ \\
\hline $\begin{array}{l}\text { Taxable } \\
\text { Income }\end{array}$ & $-7,520,000$ & $5,350,451$ & $1,645,174$ & $1,026,148$ & 770,147 \\
\hline $\begin{array}{r}\text { State Tax } \\
(5 \%+6.5 \%) \\
\end{array}$ & 864,800 & $-615,302$ & $-189,195$ & $-118,007$ & $-88,567$ \\
\hline $\begin{array}{r}\text { Federal Taxable } \\
\text { Income }\end{array}$ & $-6,655,200$ & $4,735,149$ & $1,455,979$ & 908,141 & 681,580 \\
\hline Federal Tax & $2,262,768$ & $-1,609,951$ & $-495,033$ & $-308,768$ & $-231,737$ \\
\hline $\begin{array}{l}\text { Income After } \\
\text { Tax }\end{array}$ & $-4,392,432$ & $3,125,198$ & 960,946 & 599,373 & 449,843 \\
\hline \multicolumn{6}{|l|}{ Non-cash charges } \\
\hline Depreciation & 0 & 342,960 & 587,760 & 419,760 & 299,760 \\
\hline Cost Depletion & 0 & $1,388,990$ & 542,111 & 349,387 & 257,353 \\
\hline \multicolumn{6}{|c|}{ Capital Expenditures } \\
\hline $\begin{array}{r}\text { Tangible } \\
\text { Drilling Cost }\end{array}$ & $-2,400,000$ & 0 & 0 & 0 & 0 \\
\hline Net Cash Flow & $-6,792,432$ & $4,857,148$ & $2,090,817$ & $1,368,520$ & $1,006,956$ \\
\hline PV @ (10\%) & $-6,792,432$ & $4,415,589$ & $1,727,948$ & $1,028,189$ & 687,765 \\
\hline NPV@10\%= & $\$ 3,114,000$ & & & & \\
\hline
\end{tabular}

Figure 4.11a: Cash flow statement for the third scenario, years 0 through 4. Initial production is the same as in the previous scenarios, 406 bbls. / day and 68 percent initial annual average decline rate. 


\begin{tabular}{|c|c|c|c|c|c|}
\hline Year & 5 & 6 & 7 & 8 & 9 \\
\hline \multicolumn{6}{|l|}{ Revenue } \\
\hline Production & 14,054 & 12,475 & 11,726 & 11,075 & 10,521 \\
\hline $\begin{array}{r}\text { Price of oil } \\
(\$ / \mathrm{bbl} .)\end{array}$ & 101.4 & 104.2 & 107.1 & 110.1 & 113.2 \\
\hline $\begin{array}{r}\text { Gross } \\
\text { Revenue }\end{array}$ & $1,424,796$ & $1,300,133$ & $1,256,345$ & $1,219,753$ & $1,191,211$ \\
\hline $\begin{array}{l}\text { Royalty } \\
(12.5 \%)\end{array}$ & 178,099 & 162,517 & 157,043 & 152,469 & 148,901 \\
\hline Net Revenue & $1,246,696$ & $1,137,617$ & $1,099,302$ & $1,067,284$ & $1,042,309$ \\
\hline \multicolumn{6}{|l|}{ Costs } \\
\hline $\begin{array}{r}\text { LOE (\$ per } \\
\text { bbl.) }\end{array}$ & 10 & 10 & 10 & 10 & 10 \\
\hline $\begin{array}{r}\text { LOE cost (\$ } \\
x \text { bbl.) }\end{array}$ & $-140,537$ & $-124,748$ & $-117,263$ & $-110,746$ & $-105,209$ \\
\hline $\begin{array}{r}\text { Intangible } \\
\text { Drilling } \\
\text { Costs } \\
\end{array}$ & 0 & 0 & 0 & 0 & 0 \\
\hline $\begin{array}{r}\text { Lease Cost } \\
\text { (5 year) }\end{array}$ & $-1,920,000$ & 0 & 0 & & 0 \\
\hline \multicolumn{6}{|c|}{ Non - cash costs } \\
\hline $\begin{array}{c}\text { Tangible } \\
\text { Drill. Depr. }\end{array}$ & $-214,320$ & $-214,320$ & $-214,320$ & $-107,160$ & 0 \\
\hline $\begin{array}{r}\text { Cost Based } \\
\text { Depletion } \\
\end{array}$ & $-213,719$ & $-195,020$ & $-188,452$ & $-182,963$ & $-178,682$ \\
\hline Total Costs & $-2,488,576$ & $-534,088$ & $-520,034$ & $-400,869$ & $-283,891$ \\
\hline $\begin{array}{l}\text { Taxable } \\
\text { Income }\end{array}$ & $-1,241,880$ & 603,529 & 579,267 & 666,414 & 758,419 \\
\hline $\begin{array}{r}\text { State Tax } \\
(5 \%+6.5 \%)\end{array}$ & 142,816 & $-69,406$ & $-66,616$ & $-76,638$ & $-87,218$ \\
\hline $\begin{array}{c}\text { Federal } \\
\text { Taxable } \\
\text { Income }\end{array}$ & $-1,099,064$ & 534,123 & 512,652 & 589,777 & 671,200 \\
\hline Federal Tax & 373,682 & $-181,602$ & $-174,302$ & $-200,524$ & $-228,208$ \\
\hline $\begin{array}{l}\text { Income } \\
\text { After Tax }\end{array}$ & $-725,382$ & 352,521 & 338,350 & 389,253 & 442,992 \\
\hline \multicolumn{6}{|c|}{ Non-cash charges } \\
\hline Depreciation & 214,320 & 214,320 & 214,320 & 107,160 & 0 \\
\hline $\begin{array}{r}\text { Cost } \\
\text { Depletion } \\
\end{array}$ & 213,719 & 195,020 & 188,452 & 182,963 & 178,682 \\
\hline \multicolumn{6}{|c|}{ Capital Expenditures } \\
\hline Tangible D. & 0 & 0 & 0 & 0 & 0 \\
\hline $\begin{array}{l}\text { Net Cash } \\
\text { Flow } \\
\end{array}$ & $-297,343$ & 761,861 & 741,122 & 679,376 & 621,674 \\
\hline PV (10 \%) & $-184,626$ & 430,051 & 380,313 & 316,934 & 263,650 \\
\hline
\end{tabular}

Figure 4.11b: Cash flow statement for the third scenario, years 5 through 9. 


\begin{tabular}{|c|c|c|c|c|c|}
\hline Year & 10 & 11 & 12 & 13 & 14 \\
\hline \multicolumn{6}{|l|}{ Revenue } \\
\hline Production & 9,995 & 9,495 & 9,020 & 8,569 & 8,141 \\
\hline $\begin{array}{r}\text { Price of oil } \\
(\$ / \mathrm{bbl} .)\end{array}$ & 116.4 & 119.7 & 123.0 & 126.4 & 130.0 \\
\hline $\begin{array}{r}\text { Gross } \\
\text { Revenue }\end{array}$ & $1,163,336$ & $1,136,114$ & $1,109,529$ & $1,083,566$ & $1,058,211$ \\
\hline $\begin{array}{l}\text { Royalty } \\
(12.5 \%)\end{array}$ & 145,417 & 142,014 & 138,691 & 135,446 & 132,276 \\
\hline Net Revenue & $1,017,919$ & 994,100 & 970,838 & 948,120 & 925,934 \\
\hline \multicolumn{6}{|l|}{ Costs } \\
\hline $\begin{array}{r}\text { LOE (\$ per } \\
\text { bbl.) }\end{array}$ & 10 & 10 & 10 & 10 & 10 \\
\hline $\begin{array}{r}\text { LOE cost }(\$ \\
\times \text { bbl. })\end{array}$ & $-99,949$ & $-94,951$ & $-90,204$ & $-85,694$ & $-81,409$ \\
\hline $\begin{array}{r}\text { Intangible } \\
\text { Dr. Cost }\end{array}$ & 0 & 0 & 0 & 0 & 0 \\
\hline $\begin{array}{r}\text { Lease Cost ( } 5 \\
\text { year) }\end{array}$ & $-1,920,000$ & 0 & 0 & 0 & 0 \\
\hline \multicolumn{6}{|c|}{ Non - cash costs } \\
\hline $\begin{array}{r}\text { Tangible } \\
\text { D.C. Depr. }\end{array}$ & 0 & 0 & 0 & 0 & 0 \\
\hline $\begin{array}{r}\text { Cost Based } \\
\text { Depletion } \\
(15 \%)\end{array}$ & $-174,500$ & $-170,417$ & $-166,429$ & $-162,535$ & $-158,732$ \\
\hline Total Costs & $-2,194,449$ & $-265,368$ & $-256,633$ & $-248,228$ & $-240,140$ \\
\hline $\begin{array}{l}\text { Taxable } \\
\text { Income }\end{array}$ & $-1,176,530$ & 728,732 & 714,205 & 699,892 & 685,794 \\
\hline $\begin{array}{r}\text { State Tax } \\
(5 \%+6.5 \%)\end{array}$ & 135,301 & $-83,804$ & $-82,134$ & $-80,488$ & $-78,866$ \\
\hline $\begin{array}{c}\text { Federal } \\
\text { Taxable } \\
\text { Income }\end{array}$ & $-1,041,229$ & 644,927 & 632,071 & 619,404 & 606,928 \\
\hline Federal Tax & 354,018 & $-219,275$ & $-214,904$ & $-210,598$ & $-206,355$ \\
\hline $\begin{array}{l}\text { Income } \\
\text { After Tax }\end{array}$ & $-687,211$ & 425,652 & 417,167 & 408,807 & 400,572 \\
\hline \multicolumn{6}{|c|}{ Non-cash charges } \\
\hline Depreciation & 0 & 0 & 0 & 0 & 0 \\
\hline $\begin{array}{r}\text { Cost } \\
\text { Depletion } \\
\end{array}$ & 174,500 & 170,417 & 166,429 & 162,535 & 158,732 \\
\hline \multicolumn{6}{|c|}{ Capital Expenditures } \\
\hline $\begin{array}{r}\text { Tangible } \\
\text { Drilling C. }\end{array}$ & 0 & 0 & 0 & 0 & 0 \\
\hline Net Cash F. & $-512,711$ & 596,069 & 583,597 & 571,342 & 559,304 \\
\hline PV (10\%) & $-197,672$ & 208,919 & 185,952 & 165,497 & 147,282 \\
\hline
\end{tabular}

Figure 4.11c: Cash flow statement for the third scenario, years 10 through 14 . 


\begin{tabular}{|c|c|c|c|c|c|}
\hline Year & 15 & 16 & 17 & 18 & 19 \\
\hline \multicolumn{6}{|l|}{ Revenue } \\
\hline Production & 7,734 & 7,347 & 6,980 & 6,631 & 6,299 \\
\hline $\begin{array}{r}\text { Price of oil } \\
(\$ / b b l .)\end{array}$ & 133.6 & 137.4 & 141.2 & 145.2 & 149.2 \\
\hline $\begin{array}{r}\text { Gross } \\
\text { Revenue }\end{array}$ & $1,033,449$ & $1,009,266$ & 985,649 & 962,585 & 940,060 \\
\hline $\begin{array}{l}\text { Royalty } \\
(12.5 \%)\end{array}$ & 129,181 & 126,158 & 123,206 & 120,323 & 117,508 \\
\hline $\begin{array}{l}\text { Net } \\
\text { Revenue }\end{array}$ & 904,268 & 883,108 & 862,443 & 842,262 & 822,553 \\
\hline \multicolumn{6}{|l|}{ Costs } \\
\hline $\begin{array}{r}\text { LOE (\$ per } \\
\text { bbl.) }\end{array}$ & 10 & 10 & 10 & 10 & 10 \\
\hline $\begin{array}{r}\text { LOE cost }(\$ \\
x \text { bbl.) }\end{array}$ & $-77,338$ & $-73,471$ & $-69,798$ & $-66,308$ & $-62,993$ \\
\hline $\begin{array}{c}\text { Intangible } \\
\text { Drilling C. }\end{array}$ & 0 & 0 & 0 & 0 & 0 \\
\hline $\begin{array}{r}\text { Lease Cost } \\
\text { (5 year) }\end{array}$ & $-1,920,000$ & 0 & 0 & 0 & 0 \\
\hline \multicolumn{6}{|c|}{ Non - cash costs } \\
\hline $\begin{array}{r}\text { Tangible } \\
\text { D.C. Depr. }\end{array}$ & 0 & 0 & 0 & 0 & 0 \\
\hline $\begin{array}{r}\text { Cost Based } \\
\text { Depletion } \\
(15 \%)\end{array}$ & $-155,017$ & $-151,390$ & $-147,847$ & $-144,388$ & $-141,009$ \\
\hline Total Costs & $-2,152,356$ & $-224,861$ & $-217,645$ & $-210,696$ & $-204,002$ \\
\hline $\begin{array}{l}\text { Taxable } \\
\text { Income }\end{array}$ & $-1,248,088$ & 658,246 & 644,798 & 631,566 & 618,551 \\
\hline $\begin{array}{r}\text { State Tax } \\
(5 \%+6.5 \%) \\
\end{array}$ & 143,530 & $-75,698$ & $-74,152$ & $-72,630$ & $-71,133$ \\
\hline $\begin{array}{c}\text { Federal } \\
\text { Taxable } \\
\text { Income }\end{array}$ & & & & & \\
\hline Federal Tax & $\begin{array}{r}-1,104,558 \\
375,550\end{array}$ & $\begin{array}{r}582,548 \\
-198,066\end{array}$ & $\begin{array}{r}5 / 0,040 \\
-194,020\end{array}$ & $\begin{array}{r}558,950 \\
-190,038\end{array}$ & $\begin{array}{r}54 /, 418 \\
-186,122\end{array}$ \\
\hline $\begin{array}{l}\text { Income } \\
\text { After Tax }\end{array}$ & $-729,008$ & 384,482 & 376,626 & 368,898 & 361,296 \\
\hline \multicolumn{6}{|c|}{ Non-cash charges } \\
\hline Depreciation & 0 & 0 & 0 & 0 & 0 \\
\hline $\begin{array}{r}\text { Cost } \\
\text { Depletion } \\
\end{array}$ & 155,017 & 151,390 & 147,847 & 144,388 & 141,009 \\
\hline \multicolumn{6}{|c|}{ Capital Expenditures } \\
\hline $\begin{array}{c}\text { Tangible } \\
\text { Drilling C. }\end{array}$ & 0 & 0 & 0 & 0 & 0 \\
\hline Net Cash F. & $-573,991$ & 535,872 & 524,474 & 513,285 & 502,305 \\
\hline PV (10\%) & $-137,409$ & 116,621 & 103,764 & 92,319 & 82,131 \\
\hline
\end{tabular}

Figure 4.11d: Cash flow statement for the years 15 through 19. 


\begin{tabular}{|c|c|}
\hline Year & 20 \\
\hline \multicolumn{2}{|l|}{ Revenue } \\
\hline Production & 5,984 \\
\hline Price of oil (\$/bbl.) & 153.4 \\
\hline Gross Revenue & 918,063 \\
\hline Royalty Fee $(12.5 \%)$ & 114,758 \\
\hline Net Revenue & 803,305 \\
\hline \multicolumn{2}{|l|}{ Costs } \\
\hline LOE (\$ per bbl.) & 10 \\
\hline LOE cost ( $\$ \mathrm{x}$ bbl. $)$ & $-59,843$ \\
\hline Intangible Drilling Costs & 0 \\
\hline Lease Cost (5 year) & 0 \\
\hline \multicolumn{2}{|l|}{ Non - cash costs } \\
\hline Tangible Drilling Costs Depreciation & 0 \\
\hline Cost Based Depletion (15\%) & $-137,709$ \\
\hline Total Costs & $-197,552$ \\
\hline Taxable Income & 605,753 \\
\hline State Tax $(5 \%+6.5 \%)$ & $-69,662$ \\
\hline Federal Taxable Income & 536,091 \\
\hline Federal Tax & $-182,271$ \\
\hline Income After Tax & 353,820 \\
\hline \multicolumn{2}{|l|}{ Non-cash charges } \\
\hline Depreciation & 0 \\
\hline Cost Depletion & 137,709 \\
\hline \multicolumn{2}{|l|}{ Capital Expenditures } \\
\hline Tangible Drilling Costs & 0 \\
\hline Net Cash Flow & 491,530 \\
\hline Present Value @ (10\%) & 73,063 \\
\hline
\end{tabular}

Figure 4.11e: Cash flow statements for the third scenario, year 20.

The third scenario considers a twenty year production period. It is a continuation of the last two scenarios and added 10 more years beyond the second scenario. As discussed previously, the second scenario gave better NPV and IRR results than the first scenario, even though the production rates decline every year. The same result occurs in the third scenario: it yields much better NPV and IRR results than the previous scenarios. Table 4.5 shows the results. 
Table 4.5: Profitability and EUR results for the third scenario

\begin{tabular}{|l|l|}
\hline \multicolumn{2}{|c|}{ Results for years 0 through 20 } \\
\hline NPV @ MARR=10\% & $\$ 3,114,000$ \\
\hline IRR & $26 \%$ \\
\hline EUR & 328,453 bbls. \\
\hline
\end{tabular}

The IRR is slightly higher than the second scenario, which was $25.6 \%$ and increases slightly to $26 \%$. The NPV improved similarly exceeding \$3.1 million. Thus, the third scenario shows that producing ten more years with the same well is somewhat more profitable. On the other hand, another possibility is to terminate the original well after the tenth (second scenario), and drill a new well for production over the next ten years with the same features. Will it be more profitable with given the same circumstances? The fourth scenario will answer these questions.

\subsubsection{Fourth Scenario (Another well drilled in year ten)}

The fourth scenario is a bit different from the previous scenarios. After the tenth year, a new well is drilled and produces oil for the next ten years period. Initial input variables remain same for the second well, only oil prices is different and time value of money is considered in the fourth scenario. Cash flow statement analysis is shown in Figure 4.12a, 4.12b, 4.12c, 4.12d, and 4.12e. 


\begin{tabular}{|c|c|c|c|c|c|}
\hline Year & $\mathbf{0}$ & 1 & 2 & 3 & 4 \\
\hline \multicolumn{6}{|l|}{ Revenue } \\
\hline Production & 0 & 102,004 & 38,727 & 24,279 & 17,397 \\
\hline $\begin{array}{r}\text { Price of oil } \\
\text { (\$/bbl.) }\end{array}$ & 0 & 90.8 & 93.3 & 95.9 & 98.6 \\
\hline Gross Revenue & 0 & $9,259,923$ & $3,614,074$ & $2,329,245$ & $1,715,690$ \\
\hline Royalty (12.5\%) & 0 & $1,157,490$ & 451,759 & 291,156 & 214,461 \\
\hline Net Revenue & 0 & $8,102,433$ & $3,162,314$ & $2,038,090$ & $1,501,229$ \\
\hline \multicolumn{6}{|l|}{ Costs } \\
\hline LOE (\$ per bbl.) & 0 & 10 & 10 & 10 & 10 \\
\hline $\begin{array}{r}\text { LOE cost }(\$ x \\
\text { bbl.) }\end{array}$ & 0 & $1,020,040^{-}$ & $-387,270$ & $-242,794$ & $-173,968$ \\
\hline $\begin{array}{r}\text { Intangible } \\
\text { Drilling Costs }\end{array}$ & $-5,600,000$ & 0 & 0 & 0 & 0 \\
\hline $\begin{array}{r}\text { Lease Cost (5 } \\
\text { year) } \\
\end{array}$ & $-1,920,000$ & 0 & 0 & 0 & 0 \\
\hline \multicolumn{6}{|l|}{ Non - cash costs } \\
\hline $\begin{array}{r}\text { Tangible Drilling } \\
\text { Costs } \\
\text { Depreciation }\end{array}$ & 0 & -342960 & -587760 & -410760 & 200760 \\
\hline $\begin{array}{r}\text { Cost Based } \\
\text { Depletion (15\%) }\end{array}$ & 0 & $\begin{array}{r}- \\
1,388,988\end{array}$ & $-542,111$ & $-349,387$ & $-257,353$ \\
\hline Total Costs & $-7,520,000$ & 2,751,988 & $-1,517,141$ & $-1,011,941$ & $-731,081$ \\
\hline Taxable Income & $-7,520,000$ & $5,350,444$ & $1,645,174$ & $1,026,148$ & 770,147 \\
\hline $\begin{array}{r}\text { State Tax } \\
(5 \%+6.5 \%) \\
\end{array}$ & 864,800 & $-615,301$ & $-189,195$ & $-118,007$ & $-88,567$ \\
\hline $\begin{array}{r}\text { Federal Taxable } \\
\text { Income }\end{array}$ & $-6,655,200$ & $4,735,143$ & $1,455,979$ & 908,141 & 681,580 \\
\hline Federal Tax & $2,262,768$ & 1,609,949 & $-495,033$ & $-308,768$ & $-231,737$ \\
\hline $\begin{array}{l}\text { Income After } \\
\text { Tax }\end{array}$ & $-4,392,432$ & $3,125,194$ & 960,946 & 599,373 & 449,843 \\
\hline \multicolumn{6}{|l|}{ Non-cash charges } \\
\hline Depreciation & 0 & 342,960 & 587,760 & 419,760 & 299,760 \\
\hline Cost Depletion & 0 & $1,388,988$ & 542,111 & 349,387 & 257,353 \\
\hline \multicolumn{6}{|c|}{ Capital Expenditures } \\
\hline $\begin{array}{r}\text { Tangible Drilling } \\
\text { Costs }\end{array}$ & $-2,400,000$ & 0 & 0 & 0 & 0 \\
\hline Net Cash Flow & $-6,792,432$ & $4,857,143$ & $2,090,817$ & $1,368,520$ & $1,006,956$ \\
\hline PV@ (10\%) & $-6,792,432$ & $4,415,585$ & $1,727,948$ & $1,028,189$ & 687,765 \\
\hline
\end{tabular}

Figure 4.12a: Cash flow statement for the fourth scenario, years 0 through 4 . The fourth scenario includes two different wells' production performances Initial daily production rate for each ten years is 406 bbls. / day and the initial annual decline rate is 68 percent. 


\begin{tabular}{|c|c|c|c|c|c|}
\hline Year & 5 & 6 & 7 & 8 & 9 \\
\hline \multicolumn{6}{|l|}{ Revenue } \\
\hline Production & 14,054 & 12,475 & 11,726 & 11,075 & 10,521 \\
\hline $\begin{array}{r}\text { Price of oil } \\
(\$ / \mathrm{bbl} .)\end{array}$ & 101.4 & 104.2 & 107.1 & 110.1 & 113.2 \\
\hline $\begin{array}{r}\text { Gross } \\
\text { Revenue }\end{array}$ & $1,424,796$ & $1,300,133$ & $1,256,345$ & $1,219,753$ & $1,191,211$ \\
\hline $\begin{array}{l}\text { Royalty } \\
(12.5 \%)\end{array}$ & 178,099 & 162,517 & 157,043 & 152,469 & 148,901 \\
\hline Net Revenue & $1,246,696$ & $1,137,617$ & $1,099,302$ & $1,067,284$ & $1,042,309$ \\
\hline \multicolumn{6}{|l|}{ Costs } \\
\hline $\begin{array}{r}\text { LOE (\$ per } \\
\text { bbl.) }\end{array}$ & 10 & 10 & 10 & 10 & 10 \\
\hline $\begin{array}{r}\text { LOE cost }(\$ \\
\times \text { bbl.) }\end{array}$ & $-140,537$ & $-124,748$ & $-117,263$ & $-110,746$ & $-105,209$ \\
\hline $\begin{array}{r}\text { Intangible } \\
\text { Drilling } \\
\text { Costs }\end{array}$ & 0 & 0 & 0 & 0 & 0 \\
\hline $\begin{array}{r}\text { Lease Cost ( } 5 \\
\text { year) }\end{array}$ & $-1,920,000$ & 0 & 0 & 0 & 0 \\
\hline \multicolumn{6}{|c|}{ Non - cash costs } \\
\hline $\begin{array}{r}\text { Tangible } \\
\text { Drilling } \\
\text { Costs Depr. }\end{array}$ & $-214,320$ & $-214,320$ & $-214,320$ & $-107,160$ & 0 \\
\hline $\begin{array}{r}\text { Cost Based } \\
\text { Depletion } \\
\end{array}$ & $-213,719$ & $-195,020$ & $-188,452$ & $-182,963$ & $-178,682$ \\
\hline Total Costs & $-2,488,576$ & $-534,088$ & $-520,034$ & $-400,869$ & $-283,891$ \\
\hline $\begin{array}{l}\text { Taxable } \\
\text { Income }\end{array}$ & $-1,241,880$ & 603,529 & 579,267 & 666,414 & 758,419 \\
\hline $\begin{array}{r}\text { State Tax } \\
(5 \%+6.5 \%) \\
\end{array}$ & 142,816 & $-69,406$ & $-66,616$ & $-76,638$ & $-87,218$ \\
\hline $\begin{array}{c}\text { Federal } \\
\text { Taxable } \\
\text { Income }\end{array}$ & & & & 500777 & 671200 \\
\hline Federal Tax & 373,682 & $-181,602$ & $-174,302$ & $-200,524$ & $-228,208$ \\
\hline $\begin{array}{l}\text { Income } \\
\text { After Tax }\end{array}$ & $-725,382$ & 352,521 & 338,350 & 389,253 & 442,992 \\
\hline \multicolumn{6}{|c|}{ Non-cash charges } \\
\hline Depreciation & 214,320 & 214,320 & 214,320 & 107,160 & 0 \\
\hline $\begin{array}{r}\text { Cost } \\
\text { Depletion } \\
\end{array}$ & 213,719 & 195,020 & 188,452 & 182,963 & 178,682 \\
\hline \multicolumn{6}{|c|}{ Capital Expenditures } \\
\hline Tangible D. & 0 & 0 & 0 & 0 & 0 \\
\hline $\begin{array}{l}\text { Net Cash } \\
\text { Flow } \\
\end{array}$ & $-297,343$ & 761,861 & 741,122 & 679,376 & 621,674 \\
\hline PV @ $10 \%$ & $-184,626$ & 430,051 & 380,313 & 316,934 & 263,650 \\
\hline
\end{tabular}

Figure 4.12b: Cash flow statement for the fourth scenario, years 5 through 9. 


\begin{tabular}{|c|c|c|c|c|c|}
\hline Year & 10 & 11 & 12 & 13 & 14 \\
\hline \multicolumn{6}{|l|}{ Revenue } \\
\hline Production & 9,995 & 102,004 & 38,727 & 24,279 & 17,397 \\
\hline $\begin{array}{r}\text { Price of oil } \\
(\$ / \mathrm{bbl} .)\end{array}$ & 116.4 & 119.7 & 123.0 & 126.4 & 130.0 \\
\hline $\begin{array}{r}\text { Gross } \\
\text { Revenue }\end{array}$ & $1,163,336$ & $12,205,035$ & $4,763,522$ & $3,070,057$ & $2,261,361$ \\
\hline $\begin{array}{l}\text { Royalty } \\
(12.5 \%)\end{array}$ & 145,417 & $1,525,629$ & 595,440 & 383,757 & 282,670 \\
\hline Net Revenue & $1,017,919$ & $10,679,406$ & $4,168,081$ & $2,686,300$ & $1,978,691$ \\
\hline \multicolumn{6}{|l|}{ Costs } \\
\hline $\begin{array}{r}\text { LOE (\$ per } \\
\text { bbl.) }\end{array}$ & 10 & 10 & 10 & 10 & 10 \\
\hline $\begin{array}{r}\text { LOE cost }(\$ \\
\times \text { bbl.) }\end{array}$ & $-99,949$ & $-1,020,041$ & $-387,270$ & $-242,794$ & $-173,968$ \\
\hline $\begin{array}{r}\text { Intangible } \\
\text { Dr. Cost }\end{array}$ & $-5,600,000$ & 0 & 0 & 0 & 0 \\
\hline $\begin{array}{r}\text { Lease Cost ( } 5 \\
\text { year) }\end{array}$ & $-1,920,000$ & 0 & 0 & 0 & 0 \\
\hline \multicolumn{6}{|c|}{ Non - cash costs } \\
\hline $\begin{array}{r}\text { Tangible } \\
\text { D.C. Depr. }\end{array}$ & 0 & $-342,960$ & $-587,760$ & $-419,760$ & $-299,760$ \\
\hline $\begin{array}{r}\text { Cost Based } \\
\text { Depletion }\end{array}$ & $-174,500$ & $-1,830,755$ & $-714,528$ & $-460,508$ & $-339,204$ \\
\hline Total Costs & $-7,794,449$ & $-3,193,756$ & $-1,689,558$ & $-1,123,063$ & $-812,932$ \\
\hline $\begin{array}{l}\text { Taxable } \\
\text { Income }\end{array}$ & $-6,776,530$ & $7,485,649$ & $2,478,523$ & $1,563,237$ & $1,165,759$ \\
\hline $\begin{array}{r}\text { State Tax } \\
(5 \%+6.5 \%)\end{array}$ & 779,301 & $-860,850$ & $-285,030$ & $-179,772$ & $-134,062$ \\
\hline $\begin{array}{c}\text { Federal } \\
\text { Taxable } \\
\text { Income }\end{array}$ & $-5,997,229$ & $6,624,799$ & $2,193,493$ & $1,383,464$ & $1,031,697$ \\
\hline Federal Tax & $2,039,058$ & $-2,252,432$ & $-745,788$ & $-470,378$ & $-350,777$ \\
\hline $\begin{array}{l}\text { Income } \\
\text { After Tax }\end{array}$ & $-3,958,171$ & $4,372,368$ & $1,447,705$ & 913,086 & 680,920 \\
\hline \multicolumn{6}{|c|}{ Non-cash charges } \\
\hline Depreciation & 0 & 342,960 & 587,760 & 419,760 & 299,760 \\
\hline Cost Dep. & 174,500 & $1,830,755$ & 714,528 & 460,508 & 339,204 \\
\hline \multicolumn{6}{|c|}{ Capital Expenditures } \\
\hline $\begin{array}{r}\text { Tangible } \\
\text { Drilling C. }\end{array}$ & $-2,400,000$ & 0 & 0 & 0 & 0 \\
\hline Net Cash F. & $-6,183,671$ & $6,546,083$ & $2,749,994$ & $1,793,355$ & $1,319,884$ \\
\hline PV (10\%) & $-2,384,073$ & $2,294,362$ & 876,233 & 519,471 & 347,567 \\
\hline
\end{tabular}

Figure 4.12c: Cash flow statement for the fourth scenario, years 10 through 14.

(New well drilled at the end of the tenth year) 


\begin{tabular}{|c|c|c|c|c|c|}
\hline Year & 15 & 16 & 17 & 18 & 19 \\
\hline \multicolumn{6}{|l|}{ Revenue } \\
\hline Production & 14,054 & 12,475 & 11,726 & 11,075 & 10,521 \\
\hline $\begin{array}{r}\begin{array}{r}\text { Price of oil } \\
(\$ / \mathrm{bbl} .)\end{array} \\
\end{array}$ & 133.6 & 137.4 & 141.2 & 145.2 & 149.2 \\
\hline $\begin{array}{r}\text { Gross } \\
\text { Revenue }\end{array}$ & $1,877,949$ & $1,713,638$ & $1,655,923$ & $1,607,693$ & $1,570,073$ \\
\hline $\begin{array}{l}\text { Royalty } \\
(12.5 \%)\end{array}$ & 234,744 & 214,205 & 206,990 & 200,962 & 196,259 \\
\hline Net Revenue & $1,643,205$ & $1,499,433$ & $1,448,932$ & $1,406,731$ & $1,373,814$ \\
\hline \multicolumn{6}{|l|}{ Costs } \\
\hline $\begin{array}{r}\text { LOE (\$ per } \\
\text { bbl.) }\end{array}$ & 10 & 10 & 10 & 10 & 10 \\
\hline $\begin{array}{r}\text { LOE cost }(\$ \\
\times \text { bbl. })\end{array}$ & $-140,537$ & $-124,748$ & $-117,263$ & $-110,746$ & $-105,209$ \\
\hline $\begin{array}{c}\text { Intangible } \\
\text { Drilling C. }\end{array}$ & 0 & 0 & 0 & 0 & 0 \\
\hline $\begin{array}{r}\text { Lease Cost ( } 5 \\
\text { year) }\end{array}$ & $-1,920,000$ & 0 & 0 & 0 & 0 \\
\hline \multicolumn{6}{|c|}{ Non - cash costs } \\
\hline $\begin{array}{r}\text { Tangible } \\
\text { D.C. Dep. }\end{array}$ & $-214,320$ & $-214,320$ & $-214,320$ & $-107,160$ & 0 \\
\hline $\begin{array}{r}\text { Cost Based } \\
\text { Depletion }\end{array}$ & $-281,692$ & $-257,046$ & $-248,388$ & $-241,154$ & $-235,511$ \\
\hline Total Costs & $-2,556,549$ & $-596,113$ & $-579,971$ & $-459,060$ & $-340,720$ \\
\hline $\begin{array}{l}\text { Taxable } \\
\text { Income }\end{array}$ & $-913,344$ & 903,320 & 868,961 & 947,671 & $1,033,093$ \\
\hline $\begin{array}{r}\text { State Tax } \\
(5 \%+6.5 \%)\end{array}$ & 105,035 & $-103,882$ & $-99,931$ & $-108,982$ & $-118,806$ \\
\hline $\begin{array}{c}\text { Federal } \\
\text { Taxable } \\
\text { Income }\end{array}$ & $-808,309$ & 799,438 & 769,031 & 838,689 & 914,288 \\
\hline Federal Tax & 274,825 & $-271,809$ & $-261,470$ & $-285,154$ & $-310,858$ \\
\hline $\begin{array}{l}\text { Income } \\
\text { After Tax }\end{array}$ & $-533,484$ & 527,629 & 507,560 & 553,534 & 603,430 \\
\hline \multicolumn{6}{|c|}{ Non-cash charges } \\
\hline Depreciation & 214,320 & 214,320 & 214,320 & 107,160 & 0 \\
\hline $\begin{array}{r}\text { Cost } \\
\text { Depletion } \\
\end{array}$ & 281,692 & 257,046 & 248,388 & 241,154 & 235,511 \\
\hline \multicolumn{6}{|c|}{ Capital Expenditures } \\
\hline $\begin{array}{r}\text { Tangible } \\
\text { Drilling C. }\end{array}$ & 0 & 0 & 0 & 0 & 0 \\
\hline Net Cash F. & $-37,472$ & 998,995 & 970,269 & 901,848 & 838,941 \\
\hline PV (10\%) & $-8,970$ & 217,410 & 191,962 & 162,205 & 137,174 \\
\hline
\end{tabular}

Figure 4.12d: Cash flow statement covering the years 15 through 19. 


\begin{tabular}{|c|c|}
\hline Year & 20 \\
\hline \multicolumn{2}{|l|}{ Revenue } \\
\hline Production & 9994,87 \\
\hline Price of oil (\$/bbl.) & 153,41 \\
\hline Gross Revenue & 1533332,88 \\
\hline Royalty Fee $(12.5 \%)$ & 191666,61 \\
\hline Net Revenue & 1341666,27 \\
\hline \multicolumn{2}{|l|}{ Costs } \\
\hline LOE (\$ per bbl.) & 10 \\
\hline LOE cost $(\$ x$ bbl. $)$ & $-99948,69$ \\
\hline Intangible Drilling Costs & 0 \\
\hline Lease Cost (5 year) & 0 \\
\hline \multicolumn{2}{|l|}{ Non - cash costs } \\
\hline Tangible Drilling Costs Depreciation & 0 \\
\hline Cost Based Depletion (15\%) & $-229999,93$ \\
\hline Total Costs & $-329948,61$ \\
\hline Taxable Income & 1011717,65 \\
\hline State $\operatorname{Tax}(5 \%+6.5 \%)$ & $-116347,53$ \\
\hline Federal Taxable Income & 895370,12 \\
\hline Federal Tax & $-304425,84$ \\
\hline Income After Tax & 590944,28 \\
\hline \multicolumn{2}{|l|}{ Non-cash charges } \\
\hline Depreciation & 0 \\
\hline Cost Depletion & 229999,93 \\
\hline \multicolumn{2}{|l|}{ Capital Expenditures } \\
\hline Tangible Drilling Costs & 0 \\
\hline Net Cash Flow & 820944,21 \\
\hline Present Value @ (10\%) & 122028,12 \\
\hline
\end{tabular}

Figure 4.12e: Cash flow statement for the fourth scenario, year 20.

The initial well performance for the first ten years was revitalized with the additional well's ten year performance. The highest financial results were observed in the fourth scenario with an NPV of $\$ 4.7$ million NPV and $27.3 \%$ IRR. 
Table 4.6: Profitability and EUR rate for the fourth scenario

\begin{tabular}{|l|l|}
\hline \multicolumn{2}{|c|}{ Results for years 0 through 20 } \\
\hline NPV @ MARR=10\% & $\$ 4,749,000$ \\
\hline IRR & $27.3 \%$ \\
\hline EUR & 504,505 bbls. \\
\hline
\end{tabular}

The second scenario was duplicated in the fourth one (two different wells with the same reservoir features producing oil for ten years), but the NPV and IRR results did not duplicate in the way that EUR did. When compared to the other scenarios, the fourth scenario gave the most profitable results.

\subsection{Break-even Analysis (Break-even prices)}

There are three different financial methods used based on the cash flow statements to analyze the investment profitability. The first two methods are the NPV and IRR concepts. The third one is to find the break-even prices, and this reflects the minimum oil price (per barrel) to achieve the hurdle rate that is 10 percent for the oil investments (i.e. find the price at which NPV equals to \$0 using a 10 percent discount rate). In other words, the break-even price is the price that achieves the minimum investment criteria at zero profit. In this study, the initial break-even price was assumed to be increasing by 2.8 percent per year, the same as the annual economic growth rate determined by the International Monetary Fund 
(IMF). Table 4.7 shows the minimum oil prices (per barrel) to achieve the investment hurdle rate (minimum acceptable rate of return of 10\%) of the investments.

Table 4.7: Break-even prices for different scenarios (zero NPV)

\begin{tabular}{|l|l|}
\hline \multicolumn{2}{|c|}{ Break-even prices of oil per barrel } \\
\hline 5 years of production $\left(1^{\text {st }}\right.$ scenario $)$ & $\$ 74.35$ \\
\hline 10 years of production $\left(2^{\text {nd }}\right.$ scenario $)$ & $\$ 68.81$ \\
\hline 20 years of production $\left(3^{\text {rd }}\right.$ scenario $)$ & $\$ 66.83$ \\
\hline 20 years of production, second well drilled in year $10\left(4^{\text {th }}\right.$ scenario $)$ & $\$ 63.26$ \\
\hline
\end{tabular}

Table 4.7 shows that all break-even prices for oil are lower than the initial annual average oil price ( $\$ 90.78 / \mathrm{bbl}$.). Therefore, all three methods show that these scenarios are profitable under current market circumstances in the North Dakota Bakken area. 20 years of production with drilling two different wells every tenth year ( $4^{\text {th }}$ scenario) has the lowest break-even price of $\$ 63.26$. The difference between the initial annual average oil price and the break-even price in the fourth scenario was very significant, and the break-even is almost 30 percent lower than the current initial price. The highest break-even price was $\$ 74.35$ in the first scenario due to short investment period and limited production time. In other words, higher break-even prices indicate lowest profit rate. In addition, a $\$ 3.57$ break-even 
price difference occurred between the third and fourth scenarios, thus drilling the second well lowered the break-even point of the investment.

\subsection{Comparison of Results}

The cash flow statement analysis is done by using the basic assumptions for a typical North Dakota unconventional oil well. The basic assumptions are shown in Table 4.8.

Table 4.8: Initial input variables for a typical North Dakota unconventional oil well

\begin{tabular}{|l|l|}
\hline \multicolumn{2}{|c|}{ Initial variables for the simulated Bakken well (as of mid-2014) } \\
\hline D \& C costs (Total Drilling Cost) & $\$ 8,000,000$ \\
\hline Intangible Drilling Cost & $\$ 5,600,000$ \\
\hline Tangible Drilling Cost & $\$ 2,400,000$ \\
\hline Clearbrook Oil Price (per barrel) & $\$ 90.78$ \\
\hline Royalty rate & $12.5 \%$ \\
\hline Lease operating expenses (per barrel) & $\$ 10$ \\
\hline Signing bonus fees (per acre) & $\$ 3,000$ \\
\hline Inflation (oil price increase per year) & $2.8 \%$ \\
\hline Initial annual average decline rate & $68 \%$ \\
\hline State taxes (extraction and gross production) & $11.5 \%$ \\
\hline Depletion Allowance & $15 \%$ \\
\hline Initial production rate (IP) & 406 bbls. / day \\
\hline Minimum Acceptable Rate of Return (MARR) & $10 \%$ \\
\hline
\end{tabular}


The simulation results are shown in table 4.9.

Table 4.9: Comparison of results based on the cash flow statements (NPV results are rounded to nearest thousand, IRR results are rounded to nearest tenth)

\begin{tabular}{|l|l|l|l|l|}
\hline \multicolumn{5}{|c|}{ Final results for scenarios } \\
\hline Scenarios & NPV @ 10\% & IRR & Break-even & EUR \\
\hline $1^{\text {st }}$ scenario & $\$ 1,579,000$ & $23.1 \%$ & $\$ 74.35$ & 196,461 bbls. \\
\hline $2^{\text {nd }}$ scenario & $\$ 2,508,000$ & $25.6 \%$ & $\$ 68.81$ & 252,252 bbls. \\
\hline $3^{\text {rd }}$ scenario & $\$ 3,114,000$ & $26.0 \%$ & $\$ 66.83$ & 328,453 bbls. \\
\hline $4^{\text {th }}$ scenario & $\$ 4,749,000$ & $27.3 \%$ & $\$ 63.26$ & 504,505 bbls. \\
\hline
\end{tabular}

Given these assumptions, it is obvious that extending the life of an unconventional oil well made investments more profitable. The fourth scenario almost tripled the NPV of the first one, which is the most important metric to assess the investment profitability. The IRR increased by more than 4 percent and the EUR was roughly 2.6 times the EUR of the first scenario.

The cash flow statements also highlight that the estimated life span of the investment is very important. 20 year investments give the highest profits and returns. Never-the-less, the well flow rate declines significantly after the initial years. Furthermore, the fourth scenario yields better results than the third one by drilling another well. Lease operating expenses and signing bonus fees slightly 
declined the profits between the year ten and twenty, but high oil prices balanced the production costs and the system brought positive results again.

Break-even prices were also crucial for the investment viability. The average annual oil price (mid-2014) \$90.78 /bbl. was much higher than the break-even results found via cash flow statements. $\$ 20-25$ range per barrel is more than sufficient to encourage the investments with given market conditions.

The highest NPV was achieved in the fourth scenario based on the assumptions, but doubling the second scenario did not duplicate the NPV, IRR, and break-even prices like EUR since the oil prices rose every year associated with the time value of money.

Another idea for the best investment ( $4^{\text {th }}$ scenario $)$ can be a sensitivity analysis to see variable over NPV sensitivity. What would be happen to the NPV if some variables increase by 10 percent, 20 percent or decrease by 10 percent, 20 percent? Sensitivity analysis answers this question. Changes in NPV by using different variables are shown in Table 4.10, Table 4.11, Table 4.12, Table 4.13, and Table 4.14.

Table 4.10: Changes in NPV by increasing or decreasing drilling cost (holding all else constant) (\$ values are rounded to nearest thousand)

\begin{tabular}{|c|c|c|c|c|}
\hline Variable & Change in $\%$ & Ex-NPV & New-NPV & $\%$ change in NPV \\
\hline \multirow{3}{*}{$\begin{array}{c}\text { Drilling cost } \\
(\$ 8,000,000)\end{array}$} & -20 & & $\$ 6,121,000$ & 28.9 \\
\cline { 2 - 5 } & -10 & & $45,435,000$ & 14.4 \\
\cline { 2 - 5 } & 0 (base case) & $\$ 4,749,000$ & $\$ 4,749,000$ & 0 \\
\cline { 2 - 5 } & +10 & & $\$ 4,063,000$ & -14.4 \\
\cline { 2 - 5 } & +20 & & $\$ 3,377,000$ & -28.9 \\
\hline
\end{tabular}


Table 4.11: Changes in NPV by increasing or decreasing production rate (holding all else constant) (\$ values are rounded to nearest thousand)

\begin{tabular}{|c|c|c|c|c|}
\hline Variable & Change in $\%$ & Ex-NPV & New-NPV & $\%$ change in NPV \\
\hline \multirow{3}{*}{$\begin{array}{c}\text { Oil Price } \\
\text { (\$90.78/bbl.) }\end{array}$} & -20 & & $\$ 1,616,000$ & -66.0 \\
\cline { 2 - 5 } & -10 & & $\$ 3,182,000$ & -33.0 \\
\cline { 2 - 5 } & 0 (base case) & $\$ 4,749,000$ & $\$ 4,749,000$ & 0 \\
\cline { 2 - 5 } & +10 & & $\$ 6,315,000$ & 33.0 \\
\cline { 2 - 5 } & +20 & & $\$ 7,882,000$ & 66.0 \\
\hline
\end{tabular}

Table 4.12: Changes in NPV by increasing or decreasing production rate (holding all else constant) (\$ values are rounded to nearest thousand)

\begin{tabular}{|c|c|c|c|c|}
\hline Variable & Change in $\%$ & Ex-NPV & New-NPV & $\%$ change in NPV \\
\hline \multirow{3}{*}{$\begin{array}{c}\text { Production } \\
\text { Rate (406 } \\
\text { bbl./day) }\end{array}$} & -20 & & $\$ 1,923,000$ & -59.5 \\
\cline { 2 - 5 } & 0 (base case) & $\$ 4,749,000$ & $\$ 4,749,000$ & -29.8 \\
\cline { 2 - 5 } & +10 & & $\$ 6,161,000$ & 0 \\
\cline { 2 - 5 } & +20 & & $\$ 7,574,000$ & 59.7 \\
\hline
\end{tabular}

Table 4.13: Changes in NPV by increasing or decreasing royalty fee (holding all else constant) (\$ values are rounded to nearest thousand)

\begin{tabular}{|c|c|c|c|c|}
\hline Variable & Change in $\%$ & Ex-NPV & New-NPV & $\%$ change in NPV \\
\hline \multirow{3}{*}{$\begin{array}{c}\text { Royalty rate } \\
(12.5 \% \text { of } \\
\text { gross }\end{array}$} & -20 & & $\$ 5,148,000$ & 8.4 \\
\cline { 2 - 5 } income) & -10 & & $\$ 4,948,000$ & 4.2 \\
\cline { 2 - 5 } & 0 (base case) & $\$ 4,749,000$ & $\$ 4,749,000$ & 0 \\
\cline { 2 - 5 } & +10 & & $\$ 4,549,000$ & -4.2 \\
\hline
\end{tabular}


Table 4.14: Changes in NPV by increasing or decreasing LOE (holding all else constant) (\$ values are rounded to nearest thousand)

\begin{tabular}{|c|c|c|c|c|}
\hline Variable & Change in $\%$ & Ex-NPV & New-NPV & $\%$ change in NPV \\
\hline \multirow{3}{*}{$\begin{array}{c}\text { LOE } \\
\text { (10/bbl.) }\end{array}$} & -20 & & $\$ 5,056,000$ & 6.5 \\
\cline { 2 - 5 } & -10 & & $\$ 4,903,000$ & 3.2 \\
\cline { 2 - 5 } & 0 (base case) & $\$ 4,749,000$ & $\$ 4,749,000$ & 0 \\
\cline { 2 - 5 } & +10 & & $\$ 4,595,000$ & -3.2 \\
\cline { 2 - 5 } & +20 & & $\$ 4,441,000$ & -6.5 \\
\hline
\end{tabular}

Table $4.10,4.11,4.12,4.13$, and 4.14 show changes in NPV by changing variables by -20 percent, -10 percent, +10 percent, and +20 percent. Figure 4.13 gives all these changes together in a spider diagram.

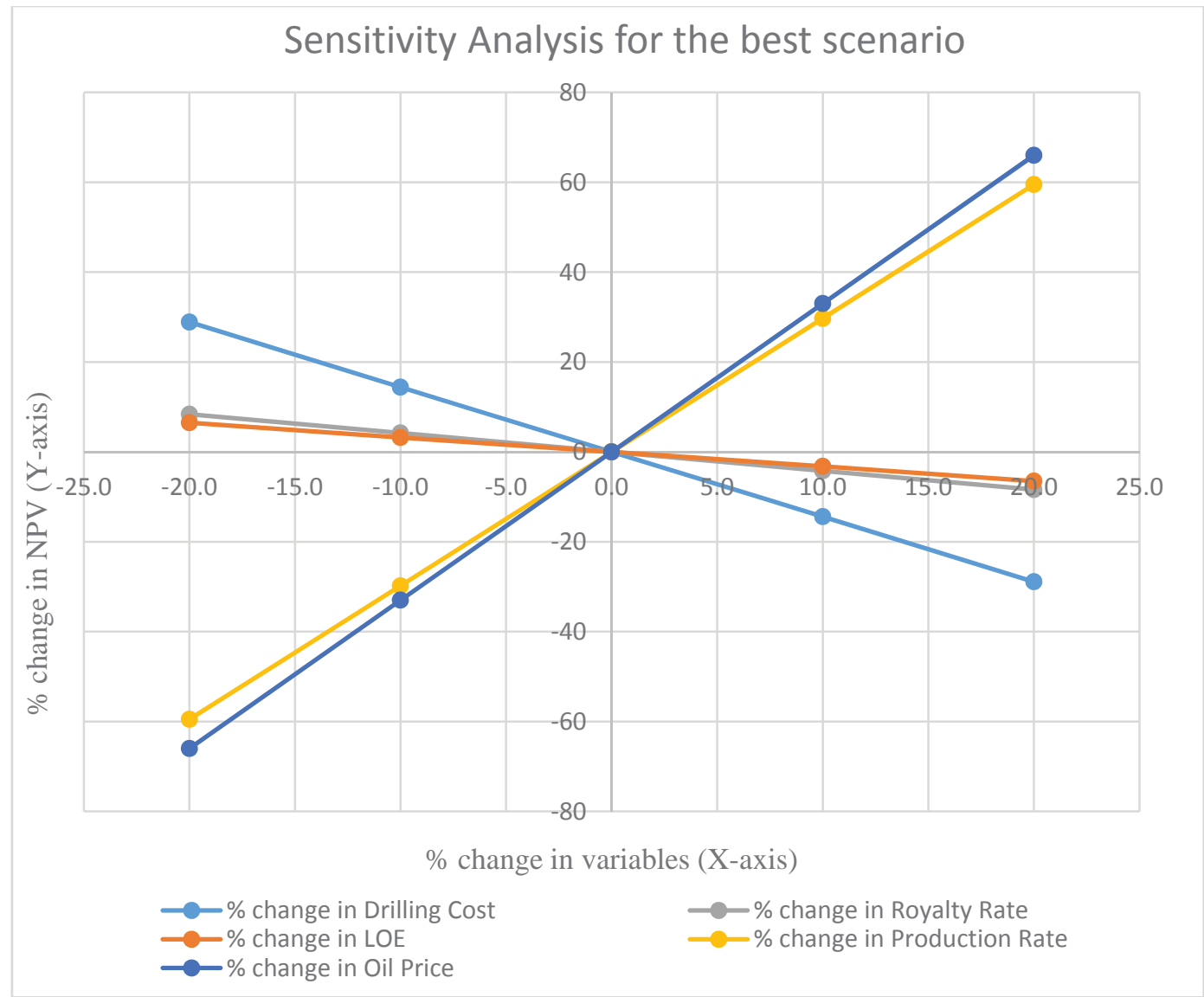

Figure 4.13: Sensitivity analysis for the best scenario ( $4^{\text {th }}$ scenario). 
Figure 4.13 shows that the highest NPV changes are observed in oil price and production rate when they increased by 20 percent (holding all else constant). When oil price is increased by 20 percent, NPV is shifted from $\$ 4,749,000$ to $\$ 7,882,000$ (66 percent increase in NPV). Similarly, when production rate is increased by 20 percent, NPV is increased to $\$ 7,574,000$ (59.5 percent increase in NPV). Also, 20 percent decrease in oil price and production rate made significant decreases in NPV. 20 percent decrease in oil price decreased NPV roughly $\$ 3.1$ million (66 percent decrease in NPV) and 20 percent decrease in production rate decreased NPV by $\$ 2.8$ million (59.5 percent decrease in NPV).

These results additionally imply that the expected well life, EUR, and the financial metrics moved together. When EUR and well life increased, the financial results enhanced too.

All in all, these scenarios presented highly attractive results for the investments in the North Dakota Bakken. Consequently, regardless of the time frame, a typical simulated Bakken unconventional oil well presented profitable investments and affirmative outcomes under these assumptions as of June 2014. Comprehensive discussions, conclusions, and adverse conditions are discussed in the following chapter (Chapter 5). 


\section{Discussion of Results}

All these scenarios gave profitable results for a simulated investment. As mentioned in the previous chapter, the most important metrics were the NPV, IRR, EUR, and break-even prices. Based on these assumptions, all of these four scenarios were acceptable and profitable for the given periods. Also, extending the well life enhanced the NPVs of the investments because of the additional oil production in the twenty year scenarios. Thus, this answers the first research question: a typical Bakken well is economically viable under conditions in mid-2014. The second question about the investment periods: a longer period is more profitable, with the NPV achieving \$4.75 million and the IRR reaching 27.3 percent (which almost tripled the net investment hurdle rate of 10 percent). The fourth scenario gave the best results, but the other scenarios were also very attractive and exceeded the minimum acceptable rate of return. Thus, a typical North Dakota unconventional oil well should be a profitable investment. However, in reality, these results are variable and will easily shift from the positive to negative if the current circumstances and assumptions change during the expected well life.

One of the main concerns is the oil price. This analysis assumes that every year the oil price increases by 2.8 percent. Table 5.1 shows that the oil price for the fifth, tenth, and the twentieth year respectively increased to $\$ 101.38, \$ 116.39$, and $\$ 153.41$ per barrel from $\$ 90.78$ / bbl. 
Table 5.1: Oil price used for each scenario. The initial price increased by 2.8 percent every year.

\begin{tabular}{|l|l|}
\hline The initial oil price for year zero & $\$ 90.78$ \\
\hline Oil price per barrel for the fifth year $\left(1^{\text {st }}\right.$ scenario $)$ & $\$ 101.38$ \\
\hline Oil price per barrel for the tenth year $\left(2^{\text {nd }}\right.$ scenario) & $\$ 116.39$ \\
\hline $\begin{array}{l}\text { Oil price per barrel for the twentieth year }\left(3^{\text {rd }}\right. \\
\left.\text { and } 4^{\text {th }} \text { scenarios }\right)\end{array}$ & $\$ 153.41$ \\
\hline
\end{tabular}

A 2.8 percent annual increase is the same as the inflation effect. On the other hand, if this price remains constant during the entire well life, how will this affect the NPV, IRR, and break-even prices for each scenario (holding all else constant)? Table 5.2 exhibits the results for this question and points out the importance of the oil price on overall economic profitability.

Table 5.2: Changes to NPV and IRR after if the oil price is held constant during the well life.

\begin{tabular}{|l|l|l|l|l|}
\hline Scenarios & Previous NPV & New NPV & Previous IRR & New IRR \\
\hline $1^{\text {st }}$ & $\$ 1,579,000$ & $\$ 1,372,000$ & $23.1 \%$ & $21.6 \%$ \\
\hline $2^{\text {nd }}$ & $\$ 2,508,000$ & $\$ 2,019,000$ & $25.6 \%$ & $23.4 \%$ \\
\hline $3^{\text {rd }}$ & $\$ 3,114,000$ & $\$ 2,186,000$ & $26.0 \%$ & $23.3 \%$ \\
\hline $4^{\text {th }}$ & $\$ 4,749,000$ & $\$ 2,797,000$ & $27.3 \%$ & $23.4 \%$ \\
\hline
\end{tabular}


If the initial oil price $(\$ 90.78 / \mathrm{bbl}$.) is kept constant during the whole well life, NPV and IRR results would decrease, especially in the last two scenarios. Based on the NPV results, a roughly two million dollar reduction would occur in the fourth scenario, a million dollar reduction would occur in the third one, and the others would also suffer. More interestingly, the ranking by IRR would change: the third scenario would lose its position; the second scenario and the fourth scenario would both have the highest IRR at $23.4 \%$. The biggest IRR loss would occur in the fourth scenario by 3.9 percent.

Table 5.2 shows that the impact of the price change was considerable and lowered the profit margin. In reality, it is impossible to estimate the oil price for 20 years because many variables can be affect it such as oversupply issues, production costs, political issues, demand changes etc. For this reason, a realistic assessment must include many price considerations to determine the sensitivity of the project to price.

Another concern is the lease operating expenses. As opposed to the oil prices, in this study these expenses remained constant for the whole period $(\$ 10$ per barrel). If the same economic growth or annual increase of 2.8 percent applied to these expenses, what would be the differences to the profitability? This question will be important because it is basically associated with the production costs and would have a significant increase on the cost side. 
Table 5.3: Changes to NPV and IRR after increasing the annual lease operating expenses by 2.8 percent per year. (NPV rounded to nearest thousand, IRR rounded to nearest tenth)

\begin{tabular}{|l|l|l|l|l|}
\hline Scenarios & Ex-NPV @ 10\% & New NPV @ 10\% & $\begin{array}{l}\text { Previous } \\
\text { IRR }\end{array}$ & New IRR \\
\hline $1^{\text {st }}$ & $\$ 1,579,000$ & $\$ 1,556,000$ & $23.1 \%$ & $22.9 \%$ \\
\hline $2^{\text {nd }}$ & $\$ 2,508,000$ & $\$ 2,453,000$ & $25.6 \%$ & $25.3 \%$ \\
\hline $3^{\text {rd }}$ & $\$ 3,114,000$ & $\$ 3,010,000$ & $26.0 \%$ & $25.7 \%$ \\
\hline $4^{\text {th }}$ & $\$ 4,749,000$ & $\$ 4,530,000$ & $27.3 \%$ & $26.9 \%$ \\
\hline
\end{tabular}

As Table 5.3 shows, increasing the LOE fees per barrel by 2.8 percent per year would slightly modify the NPV and IRR values. The highest NPV and IRR changes would happen in the fourth scenario, NPV would decline by roughly $\$ 220,000$ and the IRR would decline by 0.37 percent. The lowest changes existed in the first scenario, IRR would shift down only by 0.15 percent and NPV would decrease $\$ 23,000$. Briefly, the price effect on overall profitability is much more important than increasing the lease operating expenses.

Besides the concerns stated above, production decline rates will impact the results too. In this analysis, the initial decline was so steep that it significantly lowered the annual production (68 percent decline) after the first year. As a result of these declines, the initial flow rate of 406 bbls. / day decreased to 16 bbls. / day at the end of twenty years. 
Table 5.4: Production decline rates for a typical Bakken unconventional oil well.

\begin{tabular}{|l|l|}
\hline Years & Production decline rates per year \\
\hline 1 & $68 \%$ \\
\hline 2 & $40 \%$ \\
\hline 3 & $32 \%$ \\
\hline 4 & $22 \%$ \\
\hline 5 & $15 \%$ \\
\hline 6 & $6 \%$ \\
\hline 7 & $6 \%$ \\
\hline Years $8-20$ & $5 \%$ \\
\hline
\end{tabular}

The sharp decline in the rate of production means that a majority of the cumulative oil was extracted in the first years. For example, the initial year produced 52 percent of the total production in the first scenario. Thus, 48 percent of the cumulative oil was produced in the last four years. For the second scenario, 56 percent of the oil was produced in the first two years. The remaining eight years only provided 44 percent of the overall production. The first three years produced 50 percent of the oil in the third scenario, so the years through 4 to 20 produced the other half. Since the fourth scenario duplicated the second one, 50 percent of the cumulative oil was produced at the end of ten years. Hence, these results show the importance of the production decline rates. In some parts of North Dakota, decline rates are up to 80-85 percent in the first year. High decline rates will hinder the favorable results of this study. In addition to this, due to drilling intensity and total production increase per well, as James Mason mentioned in his studies (Mason 
2012a) (Mason 2012b), well saturation will occur much sooner than expected time and North Dakota oil investments will cease.

To summarize, a typical North Dakota Bakken unconventional oil well achieves positive results for all studied scenarios. The best economic results and EUR rates were observed in the fourth scenario, but all four of them were profitable to invest in. Under these assumptions, an oil investment in the North Dakota Bakken will be profitable and economically viable for 5 year, 10 year, and 20 year periods. Environmental issues were beyond the scope of this study, but if they are currently being included in lease operating expenses, then oil investment in North Dakota should continue to expand. 


\section{Conclusions}

Advanced horizontal drilling technologies provide access to the lateral reservoir formations. Additionally, with the support of hydraulic fracturing operations, operators are able to increase the expected recovery rate of oil. Oil prices increased significantly after the economic recession, which encouraged investors and operators to explore and develop new oil fields. As a result of enhanced drilling techniques and high oil prices, the North American tight oil sand and shale oil formations such as the Bakken Shale gained importance and became more economic to invest in. Recently, the Bakken field became the second largest oilfield in the United States. Daily production reports show that production increases day by day, and roughly 70 percent of the oil comes from unconventional resources.

As the financial calculations and cash flow statements show, a typical North Dakota Bakken unconventional oil well is profitable for 5, 10, and 20 year investment periods. Surprisingly, based on the scenario analysis, operators experienced the highest profit in the 20 year plans (the third and the fourth scenarios). However, profitable results will change in the long run depending on the production costs, sharp production declines and limited production periods, raising environmental concerns associated with hydraulic fracturing, and volatile oil prices. Oil price increases and sharp decline rates motivate Bakken operators to drill new wells right once profit margins begin to decrease. It raises the drilling intensity and leads to well saturation issues (Mason 2012b). Furthermore, due to lack of 
infrastructure and potential fracturing chemical leakages, there is an increase in environmental concerns, which may bring additional costs (external costs) into the system. These issues might increase the production costs in the long run as opposed to this analysis (costs held constant). Despite these concerns, based on the assumptions used in this analysis, a typical North Dakota Bakken unconventional oil well is profitable. In addition to this, technological developments, infrastructural improvements, and favorable economic conditions may keep production costs low. Thus, given the same conditions, Bakken unconventional oil well investments should be profitable over the long run.

Outside of the operators' point of view, unconventional oil production has direct economic benefits to the landowners, state government, and residents of North Dakota. Associated with the profitable unconventional oil investments in North Dakota, oil and gas tax revenues reached the highest levels at the end of the year 2013 , at $\$ 2.9$ billion. As a result of the high tax revenues, the state government started to fix the infrastructure issues and spent money for expanding shipping options. The state's unemployment rate has been decreasing since 2009. Companies create thousands of jobs every year. The unemployment rate of North Dakota was 4.2 percent in 2009 , and it decreased by 1.4 percent to 2.8 percent at the end of the August 2014 (Bureau of Labor Statistics 2014). Also, the state's GDP increased by 9.7 percent in 2013 (Bureau of Economic Analysis 2014).

On the other hand, oil production increases bring concerns. Drilling intensity in North Dakota will peak at some point in the future and then well 
saturation will obstruct the possible future investments. As James Mason studied, if daily production reaches 1.5 million bbls. per day, well saturation will occur in 2045. If daily production exceeds 2 million bbls. per day, saturation will occur 11 years before, in 2034 (Mason 2012b). Since the oil is non-renewable and limited, oil production cannot always increase in the long run. When compared to other states, the unconventional oil investments in North Dakota are still relatively new and operators cannot guarantee long term success along with the increasing demand. This analysis demonstrated high production declines after the initial years and operators can only mitigate declines by drilling new wells. For that reason, at the end of the tenth year in the fourth scenario, a new well was drilled and gave the highest EUR for 20 years. It is also impossible to avoid the water supply issue. Without 100 percent water re-cycling, a potential threat of water contamination will remain as an important environmental issue for the state. Moreover, higher oil production has a higher risk of pollution. Consequently, these issues will impact the economics of unconventional oil production. Financial results of the analysis indicates a $\$ 15$ to $\$ 27$ difference between break-even prices and current (mid-2014) oil prices. Thus companies might make some modifications to their environmental policies at a slight production cost increase to reduce the social costs of these potential risks.

In this analysis, 5 year investments were considered as short term and 10 to 20 year investments were assumed as long term projects. The results of the analysis highlighted the long term investment success. But in reality, market conditions and 
the demand for oil will change in the long run. If favorable economic conditions continue, profitable results are likely over the long - run. Also, inflation was not considered because some production costs were held constant in the analysis and these costs will either increase or decrease in the future.

In conclusion, considering all concerns including both recent and future issues associated with horizontal drilling and hydraulic fracturing, a typical North Dakota Bakken unconventional oil well is profitable and viable for short term and long term investments. Unconventional production has been enhancing the state's economy along with fueling the U.S. economy with regional supply. Unless there is a dramatic price change, or unexpected new supply source with conventional technologies, the unconventional oil phenomenon will continue to develop for decades because the United States Geological Survey (USGS) estimated 7.4 billion barrel of oil in the Bakken Formation in 2013 (USGS 2013). 


\section{References}

Anderson, R. (1981, last updated 2006). North Dakota Oil and Gas Leasing Considerations (C. E. Service, Trans.). Fargo, ND.

Bloomberg. (2012). U.S. Oil Output to Overtake Saudi Arabia’s by 2020.

Retrieved 06-24, 2014, from http://www.bloomberg.com/news/2012-11-12/u-s-toovertake-saudi-arabia-s-oil-production-by-2020-iea-says.html

Bloomberg (2013). U.S. to Be Top Oil Producer by 2015 on Shale, IEA Says. Retrieved 06-24, 2014, from http://www.bloomberg.com/news/2013-11-12/u-snears-energy-independence-by-2035-on-shale-boom-iea-says.html

Bureau of Economic Analysis (2014, June 11, 2014). Advance 2013 and Revised 1997-2012 Statistics of GDP by State. Retrieved October, 10, 2014, from http://www.bea.gov/newsreleases/regional/gdp_state/gsp_newsrelease.htm Bureau of Labor Statistics (2014, September 19, 2014). Regional and State Employment and Unemployment Summary. Economics News Release. Retrieved October 10, 2014, from http://www.bls.gov/news.release/laus.nr0.htm

Davies, D., (2001). Production technology II. Tech. rep., Department of Petroleum Engineering, Heriot-Watt University, Edinburgh, Scotland.

Dizard, J. (2010, March 21, 2010). The sleight of hand over shale gas costs.

Retrieved 06-11-2014, 2014, from http://www.ft.com/intl/cms/s/0/6254ec9c-33f111df-8ebf-00144feabdc0.html\#axzz35rPESKiV 
Dukes, R. T. (2013a). Hess's Bakken Drilling Days \& Well Costs Down.

Retrieved 06-22, 2014, from http://bakkenshale.com/news/hesss-bakken-drillingdays-well-costs-down/

Dukes, R. T. (2013b, October, 30, 2013). Hess' Bakken Production Grows by 14\% \& Well Costs Fall 18\%. Retrieved 06-03, 2014, from

http://bakkenshale.com/news/hess-bakken-production-grows-14-well-costs-fall-18/

Duman, R. (2012). Economic Viability of Shale Gas Production in the Marcellus

Shale; Indicated by Production Rates, Costs and Current Natural Gas Prices.

Master's Thesis, Michigan Technological University, 2012, Houghton, MI.

Retrieved from

http://services.lib.mtu.edu/etd/THESIS/2012/Business\&Economics/duman/thesis.pd $\mathrm{f}$

Earthworks. (2014). Hydraulic Fracturing 101. Retrieved 11-17, 2014, from http://www.earthworksaction.org/issues/detail/hydraulic_fracturing_101\#.VGrMYv $\mathrm{kVgqw}$

Energy Information Administration. (2010). Annual Energy Outlook

Energy Information Administration (2013a, March, 19, 2013). Bakken crude oil price differential to WTI narrows over last 14 months. Retrieved 05-04, 2014, from http://www.eia.gov/todayinenergy/detail.cfm?id=10431

Energy Information Administration (EIA) (2013b, April, 2013). Annual Energy Outlook 2013 (D. o. Energy, Trans.): Energy Information Administration. 
Energy Information Administration (2014). Annual Energy Outlook 2014 (U. S. E. I. Administration, Trans.): Energy Information Administration.

Fong, C. (2012). State and Local Taxes: An overview and Comparative Guide 2012.

Galusky, P. (2011). Feasibility Assessment of Early Flowback Water Recovery for Reuse in Subsequent Well Completions. Illinois: Gas Technology Institute.

Hefley, W.E., et al. (August, 2011). The economic impact of the value chain of a Marcellus Shale Well. University of Pittsburgh Katz Graduate School of Business Hess Corporation (2013). Barclays CEO Energy-Power Conference (pp. 13).

Hughes, J. D. (2013). Drill, Baby, Drill (2nd Edition ed.). Santa Rosa, California, USA: Post Carbon Institute.

IMF World Economic Outlook. (2014). Washington, D.C.: International Monetary Fund. from http://www.imf.org/external/pubs/ft/weo/2014/update/01/pdf/0114.pdf

Inkpen, A. C., Moffett, H. M. (2011). Global Oil \& Gas Industry: Management, Strategy, and Finance (T. Quinn Ed.). Tulsa, Oklahoma: PennWell.

Internal Revenue Service (2013a). Publication 535, Depletion. Retrieved 05-09, 2014, from http://www.irs.gov/publications/p535/ch09.html

Internal Revenue Services (2013b). Publication 946, Table of Class Lives and Recovery Periods. Retrieved 05-10, 2014, from http://www.irs.gov/publications/p946/ar02.html 
Jayakumar, R., Rai. R., Boulis, A., Araque-Martinez, A. (2013). A Systematic Study for Refracturing Modeling under Different Scenarios in Shale Reservoirs. Paper presented at the SPE Eastern Regional Meeting, Pittsburgh, PA.

Mason, J. (2012a). Bakken's maximum potential oil production rate explored. Oil \& Gas Journal.

Mason, J. (2012b). Oil Production Potential of the North Dakota Bakken. Oil and Gas Journal.

Maugeri, L. (2013). The Shale Oil Boom: A U.S. Phenomenon (K. S. B. C. f. S. a. I. Affairs, Trans.). Harvard University Kennedy School Belfer Center for Science and International Affairs.

North Dakota Oil Boom (2014). Tax Advantages of Oil and Gas Partnerships.

Retrieved 2014, from http://northdakotaoilboom.com/tax-advantages-of-oil-andgas-partnerships/

Ohio Department of Natural Resources (OHDNR) 2012. "Preliminary report on the Northstar I Class II Injection Well and the Seismic Events in the Youngstown, Ohio Area", from http://ohiodnr.com/downloads/northstar/UICreport.pdf ; last accessed 06-02-2014.

Oil and Energy Trends. (2012, 05-16-2012). Retrieved 05-16, 2012, from http://onlinelibrary.wiley.com/doi/10.1111/j.1744-7992.2012.00211.x/abstract

Pan, I. (2013, 10-25-2013). Bakken crude again trading $\$ 10$ below WTI, affecting energy names. Retrieved 06-19, 2014, from 
https://marketrealist.com/2013/10/bakken-crude-back-trading-10-wti-affectingcontinental-whiting-others/

Patterson, R. (2013, 12-13-2013). Bakken Update, Is Production Slowing Down? , 06-14-2014, from http://peakoilbarrel.com/bakken-update-production-slowing/

Petrobjects. (2004). Petroleum Reserves Estimation Methods. From http://large.stanford.edu/courses/2013/ph240/zaydullin2/docs/petrobjects.pdf

PetroChase. (2014). Tax Advantages. Retrieved 06-12, 2014, from http://petrochase.com/tax-benefits/

Robelius, F. (2007). Giant Oil Fields - The Highway to Oil. (Doctor of Philosophy), Uppsala University, Uppsala, Sweden.

Rogers, D. (2013, 04-07-2013). Is the Bakken Profitable? Retrieved 02-04, 2014, from http://energypolicyforum.org/2013/04/07/is-the-bakken-profitable/

Ryder Scott Co. LP (2011). Promising DCA techniques emerge as widespread public debate focuses on shale gas forecasts. 14(September - November 2011), 3.

Schlumberger. (2011). Retrieved 05-08, 2014, from http://www.glossary.oilfield.slb.com/en/Terms.aspx?LookIn=term\%20name\&filter= workover

Shaver, R. (2012). Water Management Issues Associated With Bakken Oil Shale Development in Western North Dakota (W. A. Division, Trans.). 
Siegel, H. (2013, 10-10-2013). Bakken 5-Year Drilling \& Completion Trends. Retrieved 10-10, 2013, from http://www.dtcenergygroup.com/bakken-5-yeardrilling-completion-trends/

Smith, G. (2014, 07-04-2014). U.S. Seen as Biggest Oil Producer after Overtaking Saudi Arabia. Retrieved 07-09-2014, 2014, from http://www.bloomberg.com/news/2014-07-04/u-s-seen-as-biggest-oil-producerafter-overtaking-saudi.html

South Western College. (2001). Depletion Deductions. Retrieved 06-02, 2014, from http://taxpoint.swcollege.com/taxpoint_2001/student/m10/m10-6.html

Stepan, D.J. and University of North Dakota Energy and Environmental Research Center for North Dakota Industrial Commission Oil and Gas Research Council (2010). Bakken Water Opportunities Assessment - Phase 1. In K. Fine (Ed.). Grand Forks, ND: Energy and Environmental Research Center.

Strother, D., Valaderes, R., Nakhwa, A.D., and Pitcher, J. (2013). Challenges of Refracturing Horizontal Wells in Unconventional and Tight Reservoirs. Society of Petroleum Engineers.

USGS. (2013). Assessment of Undiscovered Oil Resources in the Bakken and Three Forks Formations, Williston Basin Province, Montana, North Dakota, and South Dakota, 2013 (B.-T. F. A. Team, Trans.) (pp. 4).

Wegmann, P. (2014). 1,000,000 Barrels a Day and Growing: Oil Production Skyrockets in North Dakota. Retrieved 06-23, 2014, from 
http://dailysignal.com/2014/06/23/1000000-barrels-day-growing-oil-productionskyrockets-north-dakota/?utm_source=twitter\&utm_medium=social

http://www.mapsopensource.com/usa-political-map.html 